UNIVERSIDADE DE SÃO PAULO

ESCOLA DE COMUNICAÇÕES E ARTES

Vanessa Macedo da Silva Almeida

Autonomia e comunicação: a articulação de coletivos anticapitalistas em rede

SÃO PAULO 
Vanessa Macedo da Silva Almeida

\section{Autonomia e comunicação: a articulação de coletivos anticapitalistas em rede}

Dissertação apresentada à Escola de Comunicações e Artes da Universidade de São Paulo para a obtenção de título de Mestre em Ciências da Comunicação.

Área de concentração: Interfaces Sociais da Comunicação

Orientador: Prof. Dr. Celso Frederico

\section{SÃO PAULO}


ALMEIDA, Vanessa Macedo da Silva.

Autonomia e comunicação: a articulação de coletivos em rede.

Dissertação apresentada à Escola de Comunicações e Artes da Universidade de São Paulo para a obtenção de título de Mestre em Ciências da Comunicação.

Área de concentração: Interfaces Sociais da Comunicação

Orientador: Prof. Dr. Celso Frederico

Aprovada em,

Banca Examinadora

Prof. Dr. Instituição:

Julgamento: Assinatura:

Prof. Dr. Instituição:

Julgamento: Assinatura:

Prof. Dr. Instituição: Assinatura: 


\section{AGRADECIMENTOS}

Sem os ativistas construtores de redes de comunicação autônomas, esta pesquisa nem teria sido imaginada. Com entrevistas e/ou informações publicadas nos meios digitais, foi possível compreender e descrever o pensamento e a ação dos coletivos anticapitalistas.

A Nazaré e José Maria, meus pais, que nunca deixaram de confiar.

Ao professor Celso Frederico, pelas palavras inspiradoras.

A você, Vitor, por ter tornado meu percurso menos solitário. 
ALMEIDA, Vanessa M. S. Autonomia e comunicação: a articulação de coletivos

anticapitalistas em rede. 149f. Dissertação (Mestrado) - Escola de Comunicações e

Artes, Universidade de São Paulo, São Paulo: 2014.

\title{
RESUMO
}

Este trabalho busca compreender as amarras e as potencialidades em torno do uso das mídias digitais por ativistas autônomos anticapitalistas. $\mathrm{O}$ objetivo é partir da discussão sobre a potência democratizante que a Internet ativa e chegar à análise de coletivos autônomos que produzem e divulgam no espaço digital um discurso anticapitalista. Embora as novas mídias façam parte da indústria na qual a informação é mercadoria e meio de reprodução da lógica de produção vigente, a existência de grupos que usufruem das mídias digitais para criticar o atual modelo político, econômico e social contribui para o crescimento descentralizado da construção e difusão do pensamento antissistêmico. Portanto, interessa a esta pesquisa refletir sobre as origens desse ativismo e seu potencial de transformação social. A narração de episódios recentes da trajetória do movimento autônomo - o levante zapatista, a Ação Global dos Povos e as ocupações de 2011- vai ajudar na compreensão de elementos encontrados nos protestos de junho de 2013 e na formação de uma rede de coletivos em espaços físicos e virtuais. A coleta de dados de redes sociais e entrevistas com militantes basearão a descrição das ações comunicativas empreendidas por esses ativistas.

Palavras-chave: ativismo; anticapitalismo; autonomia; redes digitais; mídia radical

\begin{abstract}
This paper seeks to understand the limits and potentialities surrounding the use of digital media by autonome anticapitalist activists. The purpose is to depart from the discussion about the democratizing potency that Internet activates and reach the analysis of autonome movements that produce and publish in the digital environment an anticapitalist speech. Although new media takes part of industry where information is merchandise and way of reproducing the logic of the current production, the existence of groups that take advantage of digital media to criticize the current political, economic and social model contributes to the decentralized growth of construction and dissemination of antisystemic thought. Therefore, this research is interested in reflect on the origins of this activism and its potential for social transformation. The narration of recent episodes of the trajectory of the autonomous movement - the Zapatista insurrection, the People's Global Action and occupations in 2011 - will help in the understanding of elements found in the protests of June 2013 and the formation of a network of collectives in physical and virtual spaces. The collection of data from social networks and interviews with militants will base the description of communicative actions undertaken by these activists.
\end{abstract}

Key-words: activism; anticapitalism; autonomy; digital networks; radical media 


\section{SUMÁRIO}

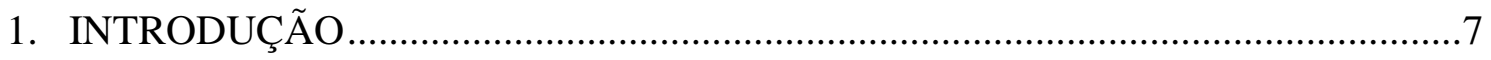

2. POTENCIALIDADES E LIMITAÇÕES DAS MÍDIAS DIGITAIS .......................12

2.1. Mutações na esfera pública e a democratização sem rupturas ...........................12

2.2. A Integração da Internet à ordem hegemônica...............................................21

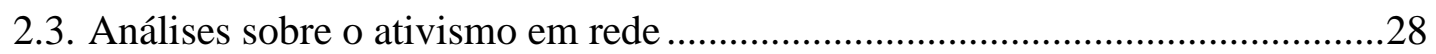

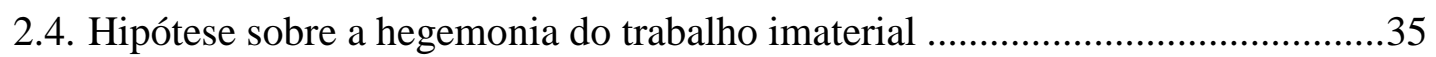

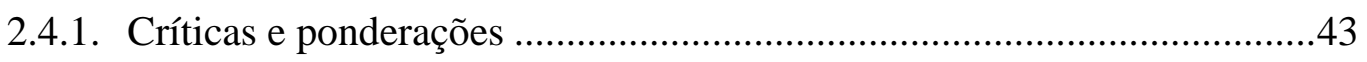

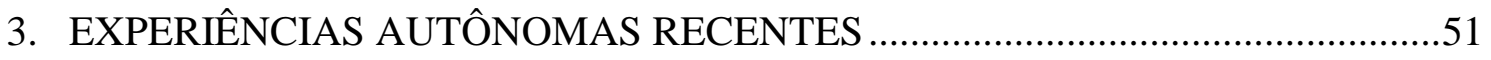

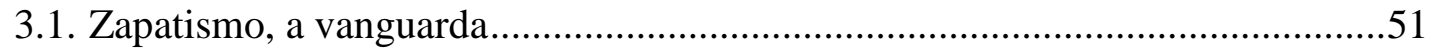

3.2. A emergência de uma rede tão global quanto o capital.....................................58

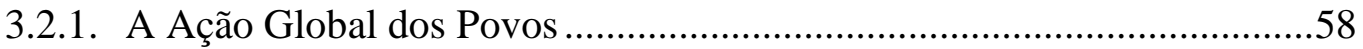

3.2.2. O Centro de Mídia Independente ..........................................................65

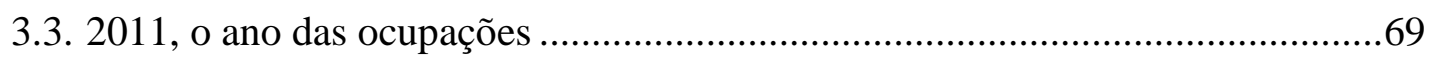

3.3.1. Breve contextualização .....................................................................69

3.3.2. Observações sobre o Ocupa Sampa .....................................................72

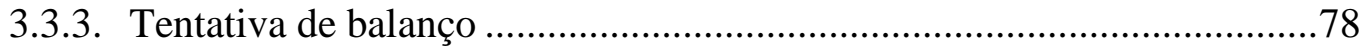

3.4. As jornadas de junho em São Paulo ................................................................. 80

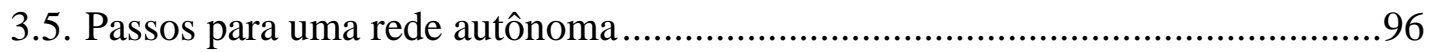

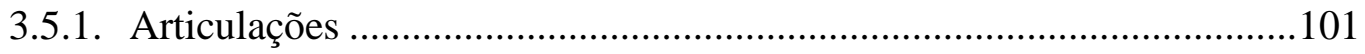

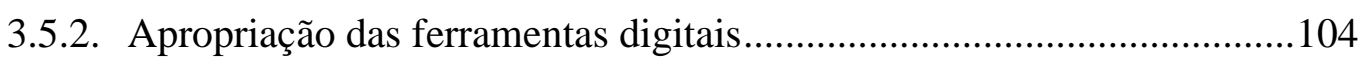

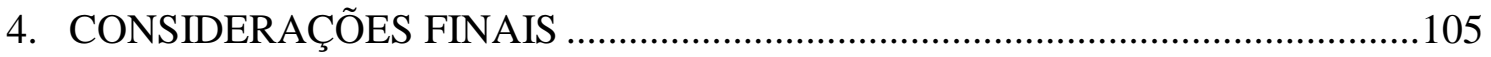

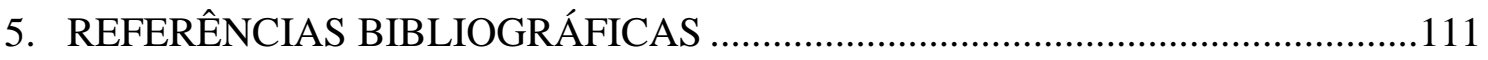

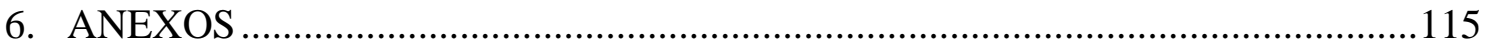




\section{1- Introdução}

Em qualquer movimento social, a divulgação de ideias, a execução de ações e a articulação com outras lutas necessitam de comunicação. Desde a consolidação do capitalismo como modo de produção social dominante, grupos políticos à esquerda lançam mão de diferentes estratégias comunicativas para criar forças de resistência e, algumas vezes, de superação. Ao longo do século passado, a concentração das emissoras de rádio e televisão em oligopólios dificultou a plena tomada desses meios pelos ativistas. Porém, no final do século, a expansão das NTIC (Novas Tecnologias de Informação e Comunicação) permitiu a criação de novas vias para a crítica à lógica econômica que sustenta a indústria de informação e entretenimento. As mudanças do âmbito da comunicação entrecruzam-se com transformações no modelo produtivo capitalista, reconfigurando as formas de fazer política.

Do final dos anos 1990 até os dias de hoje, a história dos movimentos sociais tem sido escrita por ativistas dotados de uma mídia que potencializa o alcance da informação e ultrapassa barreiras de espaço e tempo. O surgimento das redes digitais possibilitou um novo espaço de trocas para grupos que já militavam e para indivíduos que até então não eram envolvidos com o ativismo. Imersos na arena virtual, ativistas participam de mobilizações com conteúdo temático e ideológico tão diverso quanto o arsenal de informações que circula na rede. $\mathrm{O}$ entrelaçamento entre comunicação e política reforça embates históricos e lança novos conflitos e perspectivas. A Internet torna-se cenário de intensa disputa simbólica entre discursos conservadores, reformistas e revolucionários. Nessa ambiente estão os jovens engajados no ativismo apresentado por eles como autônomo e anticapitalista. É sobre esta vertente política e suas experiências de organização e comunicação que a presente pesquisa pretende discorrer.

A pesquisa aqui apresentada verifica uma mudança na forma de comunicar e de interagir no ambiente social - uma constatação corriqueira, porém repleta de questionamentos e lacunas. Embora faça parte do prolongamento da indústria na qual a informação é mercadoria e meio de reprodução simbólica, a expansão das tecnologias de comunicação ampliou o campo simbólico do sujeito. A popularização das redes virtuais enfraqueceu o modelo unidirecional empreendido pelas mídias analógicas e massivas, pois o receptor que compunha a audiência pouco ou nada interativa da 
televisão e do rádio pode produzir e disseminar conteúdos próprios com acesso a um leque muito mais diversificado de fontes.

A frequência do raciocínio acima colocado entre as pesquisas no campo da cibercultura não significa que as abordagens sejam homogêneas e unânimes quanto às implicações das chamadas novas mídias na sociedade. As linhas de pensamento dão origem a posições extremadas: os apocalípticos enfatizam o meio virtual como um campo minado pelo controle decorrente da presença ostensiva do capital privado, enquanto os ufanistas tecnológicos saúdam, sem ressalvas, o início de uma era colaborativa e democrática. Este trabalho propõe ir além do determinismo tecnológico que confere à técnica o poder de salvar ou destruir a humanidade, traçando um percurso que leve em conta as amarras e as potencialidades em torno do uso dos meios de comunicação digitais, especialmente no que se refere à atuação política.

A pesquisa localiza-se nas relações e contradições entre a suposta potência democratizante que a Internet ativa e o panorama atual de formação de movimentos autônomos nascidos em São Paulo que produzem e divulgam no espaço digital um discurso anticapitalista. A existência de grupos que usufruem das mídias digitais para promover a crítica do modelo político, econômico e social vigente a nível local e global testa os limites da contradição que a Internet carrega. Os ativistas apropriam-se de um meio de comunicação sustentado pela ordem econômica que é por eles criticado. Portanto, interessa a esta pesquisa refletir sobre o alcance desse ativismo, ou seja, seu potencial de transformar a rede em que atua e a sociedade da qual faz parte.

Este trabalho persegue as formas midiáticas empregadas pelos ativistas para disseminar reivindicações e atividades de coletivos, movimentos e redes. Assiduamente enfiados no saco homogêneo dos ciberativistas apolíticos e desprovidos de consciência, os militantes autônomos provêm de experiências histórica e socialmente condicionadas. Considerando o lugar da comunicação na infra-estrutura e superestrutura da sociedade burguesa, ora como meio de produção ora como âncora cultural e ideológica, quer-se dissertar sobre o papel da comunicação na desestruturação do capitalismo por meio das ações simbólicas e discursivas de movimentos autônomos anticapitalistas.

Antes de apresentar os objetivos dos capítulos que se seguirão, é oportuno pontuar que a divisão proposta não quer estabelecer hierarquias entre os temas tampouco afastar as relações que os tópicos mantêm entre si. Tal interpenetração certamente vai ser 
percebida quando alguns pontos forem revisitados para que se ressaltem aquelas relações necessariamente tecidas no fio da história e socialmente determinadas. Assim, evita-se que a ênfase que este estudo dá à comunicação se confunda com uma vontade de separar a comunicação da totalidade dos processos sociais.

A fim de problematizar os entraves e as potencialidades do ativismo antissistêmico articulado em redes digitais, o capítulo 2 vai mostrar que os novos meios ampliam as possibilidades de expressão e intensificam o debate sobre temas de interesse público. Entretanto, será crucial assinalar que a exaltação do potencial democrático da Internet, como faz o filósofo francês Pierre Lévy, pode obscurecer as condições sociais, políticas e econômicas por trás do avanço das tecnologias digitais. As análises de Bolaño (2000), Rüdiger (2011) e Ianni (2000) vão iluminar esse debate explicando as forças historicamente instituídas que alavancaram as tecnologias digitais. Com esse apoio teórico, a Internet deverá ser entendida como lugar de reprodução e ressignificação das contradições do mesmo sistema sócio-econômico que produziu os meios de comunicação de massa no século passado.

A compreensão do conteúdo político dos movimentos em questão vai questionar definições calcadas no pós-humanismo que descartam a centralidade da ação do homem no ativismo articuladas em contextos digitais. Assim, esta pesquisa busca combater a ideia propalada tanto na mídia quanto no meio acadêmico de que a comunicação digital tem moldado o ativismo, como se a Internet por si só incentivasse a atuação política, eliminando a importância do sujeito histórico na transformação da natureza e da sociedade. Ir contra essa visão significa sustentar que a ação humana, movida pela consciência e pela vontade, determina e é determinada por um conjunto integrado e contraditório de circunstâncias e condições sociais, econômicas e culturais. Para fundamentar uma análise contrária à noção tecnicamente determinada de ciberativismo e apontar o potencial contra-hegemônico - potencial porque pode não ser explorado - do ativismo articulado em redes digitais, será adotado o conceito de mídia radical (DOWNING, 2004).

Da nova fase de acumulação capitalista que tem nas tecnologias de informação um elemento importante, emergem antagonismos vinculados às mudanças no modo de produção e de exploração da classe trabalhadora. Por isso, o capítulo será encerrado com uma discussão sobre a tese sustentada por Negri $(2001 ; 2003)$ que supõe a 
hegemonia do trabalho imaterial. Sem deixar de mencionar críticas a essa hipótese, serão consideradas tanto a potencialidade política de resistência à democracia capitalista neoliberal quanto a fragmentação e a precarização dos trabalhadores, haja vista que o crescimento do campo de produção imaterial ao mesmo tempo potencializa e limita a luta contra-hegemônica. Potencializa porque permite, mas não garante, uma apropriação crítica dos meios de comunicação digitais e limita porque a dispersão da classe trabalhadora dificulta a integração das lutas. Essas potencialidades e limitações desafiam os coletivos que têm como princípios o anticapitalismo e a autonomia. Portanto, o foco desta pesquisa é analisar como o uso das mídias pode ser eficiente na crítica à ordem mundial e na articulação entre movimentos sociais.

Esta pesquisa busca se afastar da distinção qualitativa entre os autores que alimentam o percurso teórico. O objetivo é de, ao longo do desenvolvimento do trabalho, fazer com que diferentes abordagens teóricas se relacionem entre si de uma maneira construtiva, apesar dos paradoxos que mantêm, e não definitivamente conflitante. Talvez a coabitação e a possível interação entre as interpretações consigam fomentar uma compreensão suficientemente ampla da realidade em estudo. Um olhar aberto sobre as significações das divergências e semelhanças entre teorias não se traduz em uma linha embaçada e forçosamente imparcial que frequentemente constitui a pesquisa científica; há um fio que conduz a incursão teórica que aqui se faz, um foco de análise que justifica a elaboração deste estudo. Trata-se de uma contribuição para a crítica transformadora e radical: a modesta tentativa, mas potencialmente grande, de apreender o desenrolar das ações explicitamente contrárias ao modelo de sociedade dominante.

As finalidades do capítulo 3 são duas. Uma é a narração de momentos recentes da trajetória do autonomismo movimentos e episódios significativos, como o zapatismo nos anos 1990, a Ação Global dos Povos na virada do século e as ocupações em 2011. A outra consiste na análise dos protestos de junho e da consequente formação de uma rede de coletivos autônomos anticapitalistas espalhados em espaços públicos e virtuais.

O movimento zapatista, no México, e a Ação Global dos Povos foram experiências que exerceram grande influência sobre atual o ativismo que se proclama autônomo (FIGUEIREDO, 2006; LIBERATO, 2006). Muitas das críticas feitas ao capitalismo no fim da década de 1990 por esses movimentos foram reavivadas durante os protestos no Oriente Médio e as manifestações na Europa e Estados Unidos, em 2011. A onda de 
revoltas e ocupações de lugares públicos repercutiu no mundo todo, inclusive no Brasil, onde foram armadas acampadas que simbolizavam um modelo de sociedade livre e igualitária. Em junho de 2013, ativistas protestaram pela revogação do aumento da passagem de ônibus. As manifestações que lotaram as principais avenidas da capital paulista foram convocadas pelo Movimento Passe Livre (MPL) e fortaleceram a articulação autônoma.

Dessa forma, este trabalho lança a hipótese de que a comunicação digital contribui para o crescimento descentralizado da construção e difusão do pensamento antissistêmico, colocando a crítica ao capitalismo no meio do confronto de ideias favorecido e amplificado pelo caráter participativo da Internet. A aceleração do processo de debate sobre os problemas sociais tem relação direta com a velocidade das transformações sociais, pois, como lembrou Harvey, citando Marx, "erigimos nossa estrutura na imaginação antes de a erigirmos na realidade” (MARX apud HARVEY, 1992, p.309).

Enquanto sistema de pensamento racional que reflete o movimento real das transformações sociais, o método dialético de análise proposto por Marx conduz esta pesquisa. Apreender o concreto como concreto por unificar múltiplas determinações fortalece a noção de totalidade que impede o isolamento de qualquer objeto. Por isso, diz ele, "o concreto aparece no pensamento como o processo da síntese, como resultado, não como ponto de partida, embora seja o verdadeiro ponto de partida e, portanto, o ponto de partida também da intuição e da representação" (MARX, 2008, p. 258). Fundado conceitualmente no materialismo histórico, o método considera as condições históricas e materiais que determinam o processo da vida social e política; enxerga contradições entre as forças produtivas materiais da sociedade e as relações de produção existentes. É o instrumento de uma perspectiva segundo a qual as relações entre particular e universal e sujeito e objeto não representam dualidades, mas unidades que servem de matéria-prima no processo de construção do conhecimento.

Assim, entende-se que as estratégicas comunicativas criadas para integrar movimentos autônomos anticapitalistas são determinadas contraditoriamente pelas condições materiais e históricas da atual fase de desenvolvimento da sociedade burguesa. Por essa razão esta pesquisa se interessa em analisar eventos históricos do autonomismo e o papel atribuído à comunicação na luta anticapitalista. A ação comunicativa desses movimentos deve ser compreendida dentro dos limites impostos pela lógica capitalista - 
e também por falhas e incongruências do próprio movimento - e das supostas brechas abertas pela comunicação digital.

A pesquisa bibliográfica e a contextualização histórica darão suporte para a análise das ações comunicativas em mídias digitais empreendidas por coletivos autônomos. Ganharão relevo as iniciativas tomadas em rede, ou seja, ações de comunicação que articulam coletivos autônomos a fim de divulgar informações e fortificar vínculos. Informações coletadas em blogs, redes sociais e atividades presenciais complementarão as entrevistas feitas com militantes. A descrição de princípios, reivindicações e atividades deve ressaltar as especificidades dos grupos ativistas e as semelhanças que os integram. Atenção especial vai ser dada ao Mídia Negra, coletivo criado após as jornadas de junho que pretende ser um veículo de comunicação que visa integrar movimentos e coletivos anticapitalistas. A técnica da entrevista em profundidade será aplicada para captar como ativistas de diferentes coletivos se organizam e usam as redes digitais para efetuar a crítica à sociedade capitalista. Saber os princípios e critérios usados na cobertura de eventos vai ajudar a elucidar as características dessa rede autônoma.

Esta pesquisa não pretende provar se os movimentos anticapitalistas movem com ou sem êxito algum tipo de transformação da sociedade, mas acompanhar as cisões e as junções desse processo. A análise dos conteúdos veiculados nas mídias digitais revela que as tensões do cotidiano da vida social estão vinculadas às tensões teóricas; as questões que suscitam os embates acadêmicos dizem respeito aos embates "fora" das universidades. As aspas ironizam a leitura particularizada da sociedade, a negação da existência de um todo complexo. A partir dessa perspectiva, entende-se que a reflexão sobre as formas e estratégias de comunicação se mostrará um caminho para apontar os desafios enfrentados pela esquerda.

\section{2- Potencialidades e limitações em torno do uso das mídias digitais}

2.1- Mutações na esfera pública e democratização sem rupturas

Tomando a comunicação entre cidadãos e instituições como uma das condições importantes para se aprofundar a democracia, pluralizando as vozes e legitimando as lutas sociais, a noção de esfera pública ainda figura como um referencial teórico crucial 
para se analisarem as condições de debate e formação de opinião na arena - seja presencial, mediada ou em rede - onde se discutem as questões de interesse social. Logo, devem ser considerados o nível de participação dos indivíduos, os mecanismos de debate público e a chegada de suas vozes e demandas à esfera do poder institucionalizado.

A contribuição de Habermas (1984) para a compreensão da formação de espaços de conversação explicita elementos que dificultam a construção de uma esfera pública ampla e igualitária. Seu estudo genealógico questionou a legitimidade das ágoras da Atenas Antiga que excluíam mulheres, escravos e estrangeiros e investigou o surgimento da esfera pública burguesa europeia no século 18. Cafés, salões e salas de visita representavam as esferas públicas presenciais destinadas a indivíduos pertencentes à elite econômica e intelectual. Segundo Bucci (2009), a esfera pública burguesa primeva pode mesmo ser pensada como um metamercado, isto é, como aquele fórum embrionário que projetava para a visibilidade pública o que expressavam cidadãos vinculados a ocupações comerciais capitalistas (ou pré-capitalistas) privadas. Ou seja: na esfera pública, o comerciante burguês adquire a projeção de cidadão em diálogo com outros cidadãos (BUCCI, 2009, p. 9). Os meios de comunicação de massa viriam atenuar o caráter exclusivista e elitista ao incluir setores marginalizados, porém a massificação da informação produzida por um restrito grupo de veículos comprometeu a diversificação e aprofundamento dos assuntos públicos.

A confiança na pureza do debate público, no qual contradições e ruídos não têm espaço e a busca pela verdade é o objetivo final, pôs em xeque a conceituação mais idealista do que realista do filósofo alemão. Ao contrapor o pensamento habermasiano ao de Niklas Luhmann, que entendia o paradoxo como base para a construção da opinião pública, Marcondes Filho (2008) faz uma análise a fim de transpor a oposição e inserir a opinião pública no contexto das tecnologias comunicacionais. Luhmann (1974) considera o paradoxo gerador de incertezas, permitindo que os agentes da esfera pública entendam aspectos do tema tratado que antes desconheciam. Contudo, para este autor o componente sistêmico é superior aos indivíduos. Assim, informações dispersas se aglutinariam sob critérios de visibilidade do sistema fechado dos meios de comunicação e constituiriam uma opinião pública, estrutura de temas da comunicação pública fruto de consensos e dissensos que automaticamente influenciaria as regras de atenção e decisão do sistema político. 
Se, de acordo com Luhmann, a opinião pública resulta da fusão do médium (produto suporte dos meios de comunicação) com a forma (seleção de temas), qual vetor ligaria os dois elementos? Com o conceito de contínuo midiático, Marcondes Filho busca preencher a lacuna e ir mais longe do que Habermas no entendimento sobre a relação de colonização que o sistema impõe ao mundo vivido. Para fundamentar o conceito, Marcondes cita a construção de um acontecimento midiático. Um veículo divulga uma notícia que repercute em outros veículos e ganha visibilidade nacional. A duração do tema na agenda social depende do contínuo midiático, que exerce maior influência em atmosferas mais amplas em que as pessoas não interagem diretamente. Entendido nos anos 1940 como indústria cultural, esse elemento

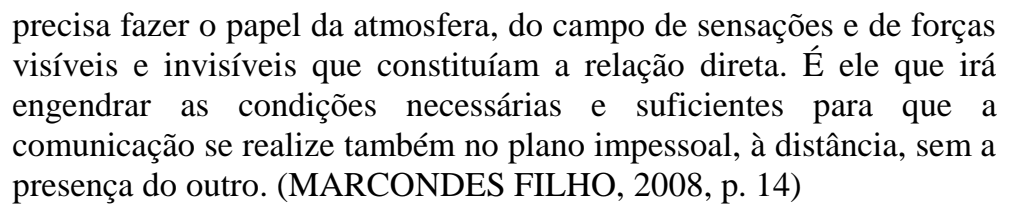

$\mathrm{Na}$ comunicação espectral ou em rede, o contínuo midiático direciona o fluxo informacional que une múltiplos nós. A importância da linguagem, que para Habermas era maior nas relações interpessoais, é levada para a Internet. Dotada de certa autonomia, a tecnologia opõe-se à massa indistinta de internautas distribuída de maneira difusa e aleatória, e "é nesse meio indistinto, disperso, mas que, como uma neblina, guarda certas formas aparentes que os distinguem, que atua o espaço-entre do contínuo atmosférico" (MARCONDES FILHO, 2008, p. 11).

O conceito habermasiano também foi ponto de partida para a análise de Bucci sobre as mutações sofridas pela espera pública. Segundo ele, a internet prolongou a instância da imagem ao vivo, fundada pelo fenômeno televisivo em resposta às exigências do capital e do espetáculo. A imagem eletrônica deu início a um processo de constituição de um mercado imaginário e global, no qual estão à venda os signos que representam as mercadorias antes restritas às fábricas de origem e ao suporte material dos veículos impressos. Embora Bucci reconheça que a palavra escrita ou falada exerça função fundamental, o que unifica os indivíduos é a instância da imagem ao vivo que reveste os temas de interesse público de uma pauta global. "Cidadãos do mundo todo identificamse, progressivamente, como pertencentes a uma agenda comum, cujos tópicos lhes dizem respeito, qualquer que seja a sua nacionalidade" (BUCCI, 2009, p.6). 
Bucci (2009) argumenta que a instância da imagem ao vivo age na constituição das relações comunicativas que fundam a esfera pública. A ênfase no conflito em detrimento da utopia do consenso é um dos deslocamentos realizados por ele em relação ao espaço público tradicional. Além de constatar que no telespaço público - conceito que, embora marcado pelo advento da televisão, mantém e expande seu sentido com a difusão das novas mídias - o consenso não passa de simulação e a opinião pública não passa de espetáculo, Bucci ressalta que na obra de Habermas o sistema de circulação de mercadorias consta como irmã gêmea da esfera pública no século XVIII, o que relativiza o véu romântico com que muitas vezes a esfera pública é coberta.

Bucci afirma que os espaços públicos são abastecidos de contradições - históricas, sociais, econômicas, políticas e, por certo, comunicacionais. A complexidade dos conflitos reduz a possibilidades de consensos, porém a existência de grupos articulados pelas e nas redes digitais para organizar mobilizações contra a sociedade capitalista pode significar que há resistência no telespaço público, embora ela se dê junto - e às vezes semelhante - aos signos da indústria do entretenimento. Mesmo que a Internet tenha dado prosseguimento à colonização do mundo da vida, não foram apenas os significantes das mercadorias-imagens que se multiplicaram, mas também as formas de contestar o status quo.

A cultura de massas, resultado da produção em larga escala de mercadorias culturais (ADORNO et HOCKHEIMER, 1997), não é a única fonte do conteúdo a preencher o espaço-entre que integra os indivíduos aos temas que formarão a opinião pública. $\mathrm{O}$ aumento das possibilidades comunicativas multiplica a quantidade de elementos que farão a ponte entre o indivíduo e os temas de interesse público, portanto amplia os pontos de vista e as variáveis da opinião pública. A captação e ressonância dos problemas sociais e a incorporação de novos temas à agenda pública ganham novos atores e novas estratégias de ação com a diversificação das esferas públicas alternativas. Por isso, a garantia da igualdade de acesso a tais espaços através da adoção de mecanismos e procedimentos de participação é tão necessária quanto o equilíbrio entre a formação da vontade pública e o fluxo espontâneo de comunicação.

A Internet intensifica o antigo debate sobre a pluralização dos meios de comunicação e reacende a crítica às barreiras políticas, sociais e econômicas que atrasam o processo de democratização. Ao mesmo tempo em que emissoras de televisão e rádio e jornais 
impressos entraram no ciberespaço com versões e inovações digitais, veículos que não tinham força para se sustentar no meio analógico diante do poderio econômico das grandes corporações migraram para a rede. A disputa pela visibilidade na esfera pública teve expandido o número de atores, interesses e visões de mundo. Os limites entre o profissionalismo e o amadorismo diluíram com a profusão de informações de infindáveis origens no território virtual.

Lévy (1999) supõe que a multiplicação de fontes de informação decorrente das mídias digitais gera mudanças significativas na esfera pública. A expansão das redes virtuais, segundo ele, fundou um novo ambiente tecnossocial no qual conteúdos são consumidos, produzidos, disseminados e debatidos. Mais do que uma ferramenta de comunicação, a Internet é um espaço de vivência. A partir dessa observação o filósofo francês argumenta o surgimento da cibercultura, um conjunto de práticas e valores presente no ciberespaço, ambiente que abriga a infraestrutura material da comunicação digital, o universo oceânico de informações e os indivíduos que o habitam.

Acompanhando a evolução da comunicação da web, Lévy $(2010)^{1}$ confirma o que ele chama de sua intuição fundamental: a liberação da expressão pública permitida pelo ciberespaço. Ele sustenta a ideia de uma esfera pública mundial em plano quantitativo, o aumento de pessoas conectadas em países industrializados e em desenvolvimento, e qualitativo. A web 2.0, termo que designa novos tipos de aplicações e usos como as redes sociais, representa para Lévy a criação e o compartilhamento colaborativos de memórias numéricas coletivas em escala global. Essas memórias englobam arquivos de imagens, vídeos, música e conhecimento enciclopédico que podem ser produzidos e organizados pelos próprios utilizadores.

No clima intelectual da computação social, a avaliação, a crítica, a categorização não são mais reservadas aos mediadores culturais tradicionais (clero, professores, jornalistas, editores), mas retorna às mãos das multidões. (LÉVY; LEMOS; 2006, p. 11)

Assim, o autor ressalta que a abertura, a relação entre pares e a colaboração caracterizam a nova forma de comunicação pública, que não se limita a territórios geográficos. O que recorta esse ambiente digital, afirma ele, são as línguas, culturas e

\footnotetext{
${ }^{1}$ Em prefácio de "O futuro da Internet", publicado em 2010. A versão atualizada de "Cibercultura”, lançado em 2002, tem tradução e coautoria de André Lemos. A edição reproduz fielmente as idéias do primeiro livro, porém acrescenta informações mais recentes em relação à comunicação na web e à realidade brasileira.
} 
centros de interesse. No lugar do estilo de emissão de um para muitos, consagrado pelas mídias analógicas, estabelece-se o modelo de muitos para muitos no qual são as pessoas que polarizam a comunicação e promovem a crítica e a filtragem dos conteúdos. No entanto, essa mudança não significa simplesmente a passagem da passividade à atividade. É bom lembrar que durante as décadas de 60 e 70, bem antes da popularização da Internet, os estudos culturais e semiológicos já indicavam quão heterogêneos são os processos de recepção, que produzem significados próprios. A essa altura, o emissor não era mais considerado o agente magnânimo, que dirige a mensagem sem ruídos ou distorções para uma massa atomizada e passiva.

Logo, a Internet potencializou e redimensionou a capacidade do público de reagir aos conteúdos emitidos pelos meios de comunicação de massa. À audiência dos veículos de informação tradicionais foi oferecida a possibilidade de emitir conteúdos com um alcance geográfico ilimitado, embaçando a distinção entre emissor e receptor. A redefinição do paradigma informacional repercutiu no olhar das teorias da comunicação, que saíram de uma concepção instrumental da transmissão de informações para uma concepção que leva em conta a complexidade dos fluxos comunicativos.

\footnotetext{
Assim, pouco a pouco o pesquisador passa da observação externa ao processo comunicativo, que the permitiria descrevê-lo em termos quantitativos e formais, para uma abordagem cada vez mais complexa dos fluxos comunicativos, avançando em direção a uma análise reticular dos mesmos, típica das redes digitais, onde ele, pesquisador, se encontra enquanto parte independente do ambiente comunicacional. Essa perspectiva pode ser considerada como decorrente de uma crise da frontalidade na pesquisa em comunicação.(DI FELICE; TORRES; YANAZE; 2012, p. 51)
}

Apesar de difusas e descentralizadas, as redes digitais proporcionam a articulação colaborativa entre grupos além das fronteiras geográficas. A comunicação digital pode se desprender da agenda das mídias tradicionais atuantes na estandardização cultural e disseminar sua própria agenda com amplo alcance. Porém, a convivência entre os dois modelos midiáticos é cada vez mais intensa e não tem um significado necessariamente negativo. Lemos (2006) ressalta que a emissão em rede não substitui a emissão massiva; ambas coexistem e se retroalimentam. De acordo com ele, o sistema infocomunicacional massivo é tensionado pelo pós-massivo na medida em que as redes digitais criam a potência, que ainda precisa ser efetivamente garantida, para a reconfiguração social e política. 
A estrutura massiva é importante para formar o público, para dar um sentido de comunidade de pertencimento local, de esfera pública enraizada. O sistema pós-massivo permite a personalização, o debate não-mediado, a conversação livre, a desterritorialização planetária. (LÉVY; LEMOS; 2006, p.26)

Essa retroalimentação entre os meios analógicos e digitais ora mantém a ordem estabelecida ora gera conflitos potencialmente transformadores. A possibilidade do conflito reside na capacidade de contestar o caráter monopolista e homogeneizante da grande mídia, o que depende do emprego das mídias digitais para expressar descontentamento e provocar mudanças.

O interesse nos processos de lutas simbólicas acentuados pela conectividade e pelo amplo uso de redes sociais - que deixam expostos a todos os usuários as informações publicadas e compartilhadas por eles mesmos - é uma grande motivação desta pesquisa. Surgem discussões sobre formas de discriminação que há muito tempo justificam a ação de movimentos sociais que combatem o racismo, a homofobia, o machismo e outras maneiras de opressão. Diariamente esses debates viram quedas de braços animadas pela oposição entre conservadores e progressistas, impulsionando mobilizações que cobram mudanças imediatas, como a saída do deputado federal Marcos Feliciano da presidência da Comissão de Direitos Humanos, por sua conduta contrária à validação dos direitos dos homossexuais.

Em ambientes digitais como o Facebook e Twitter pululam postagens que desencadeiam reações concordantes e discordantes. Opiniões pessoais liberadas na esfera pública virtual são curtidas e compartilhadas por aqueles que se sentem contemplados ou são rebatidas por posicionamentos antagônicos. As tensões verbais indicam a centralidade da questão sobre o direito de ter direitos; e o direito primeiro é a liberdade de expressão, uma conquista buscada cotidianamente. E quando os conflitos ganham vigorosamente os espaços físicos, ou voltam a estes, os impasses se amplificam e pressionam o poder institucional e a própria estrutura das redes digitais. Esse movimento tensional chacoalha a ordem estabelecida e adquire força para transformar a sociedade em variáveis medidas.

A crença no potencial transformador da cibercultura parece acompanhar o aumento exponencial da quantidade de internautas. A existência de 2,4 bilhões de usuários de Internet no mundo, segundo estatísticas de 2012 publicadas pela InternetWorldStats, revela um aumento de mais de $500 \%$ da população conectada em relação a 2000 . Lemos 
(2006) pondera que a taxa de penetração é maior em países desenvolvidos, embora seja notável o crescimento do número de internautas na África, Oriente Médio, América Latina e Caribe. O contraste reflete as pedras no caminho da concretização de uma sociedade verdadeiramente democrática travada pela concentração de riqueza e pela desigualdade social, das quais a exclusão digital é sintoma.

Lemos lança os desafios do novo contexto político-comunicacional que fortaleceria a democracia amparada em tecnologias digitais, idealização que de forma mais ou menos explícita circunda as mobilizações articuladas na esfera virtual. "Quanto mais podemos livremente produzir, distribuir e compartilhar informação, mais inteligente e politicamente consciente uma sociedade deve ficar" (LEMOS; 2006, p. 27). Para ele, a dimensão política está no vínculo entre a comunicação enquanto potência social e a técnica enquanto potência da ação. Vislumbrar a ciberdemocracia requer uma projeção muito além do que a realidade traz na prática, pois depende da efetivação do alcance planetário de questões locais, da inclusão e alfabetização digitais irrestritas e da livre expressão para publicação e troca de informações.

Aos olhos de Lévy (2002), a cibercultura pode tornar possível a existência de uma sociedade democrática que tem na junção entre isonomia e autonomia a base para a construção da inteligência coletiva. Seria um processo de autocriação sem um plano definido, mas que desenvolveria um progresso moral capaz de alargar o espaço de sentido e liberdade, metamorfoseando a relação do cidadão com a política e o Estado. Conforme essa visão, a procura comum por uma regra mais justa, imparcial e universal move a inteligência coletiva na velocidade da atualização do ciberespaço.

\footnotetext{
A civilização do tempo real gera um estado de inadequação do pensamento salutar e permanente, visto que o mundo aí se revela constantemente mais empenhado no futuro do que o podemos imaginar. Se este novo ritmo continuar, quase já não haverá qualquer diferença entre o momento da ideia e o da sua concretização. (LÉVY, 2002, p. 23)
}

A globalização e a fundação de um espaço de comunicação geográfica e semanticamente ilimitado enaltecem as relações de interdependência, o que, segundo Lévy, relativiza o poder territorial dos governos. Tal conexão torna necessária a presença transparente das gestões públicas nas ágoras virtuais e a formação de governos eletrônicos submetidos a uma ordem globalizada. A abertura de espaços para diálogo e 
deliberação políticos diminuiria a autoridade dos governantes sobre os cidadãos e enfatizaria a função de prestação de serviços, em vez do controle autoritário.

Pouco pragmático, Lévy não traça o percurso concreto ao encontro da civilização global democrática. Admite que a ciberdemocracia do futuro ainda é dificilmente imaginável e que vivemos a faísca inicial ou a pré-história da cibercultura mundial e de sua esfera pública. Um dos problemas apontados por Lévy em suas elucubrações é a profunda fragmentação da esfera pública interconectada causada pela multiplicidade de línguas, cujos léxicos e gramáticas são deveras irregulares. Logo, a ausência de um sistema universal de endereçamentos de conceitos trava a coordenação e sincronização de uma memória mundial.

Para resolver esse impasse, a solução por ele sugerida é o fim da centralização dos dados por motores de pesquisa com algoritmos secretos e uniformes e a criação de "uma sociedade descentralizada e colaborativa de agentes semânticos onde cada um exprimiria o ponto de vista e os interesses das pessoas ou das redes que eles controlam" (LÉVY; LEMOS; 2006, p. 18). Um dos efeitos principais da unificação desse campo semântico seria a total acessibilidade dos conteúdos fundamentais das ciências sociais, o que tornaria a deliberação coletiva inseparável da "prática massivamente distribuída das ciências humanas e de um diálogo hermenêutico se exercendo livremente sobre a memória mundial" (idem, p. 19).

Em certa medida, esta pesquisa valoriza as potencialidades democráticas das mídias digitais aferidas por Lemos e Lévy, porém, certas lacunas deixadas pelos autores exigem o aprofundamento da compreensão sobre a realidade na qual a Internet é instaurada. A ampliação da esfera pública e da capacidade comunicativa dos indivíduos cria novas possibilidades para o exercício da democracia, mas não é suficiente para reverter as contradições inerentes à estrutura capitalista de produção e consumo. A simples vinculação dos meios digitais com a consolidação da democracia - aliás, de qual democracia estamos falando? - pode tornar-se uma armadilha para aqueles interessados em uma discussão aprofundada sobre as reais potencialidades do uso da Internet. A Internet, por si só, não leva à transformação da sociedade, portanto as condições econômicas, sociais e políticas dadas historicamente devem ser consideradas para que as mudanças sejam pensadas em toda a sua complexidade. Isso posto, a conquista de uma sociedade democrática sem a contestação da estrutura material do 
neoliberalismo é uma inferência insustentável, pois atribui à mídia a transformação que só as lutas sociais permitem acontecer.

\section{2- A integração da Internet à ordem hegemônica}

Mesmo que se apregoe a natureza fragmentária da sociedade em que vivemos, não é intuito desta pesquisa prescindir da inserção do ciberativismo em uma noção de totalidade. A internet decorre de um processo histórico de invenção de meios de comunicação, logo não pode ser encarada como um fenômeno alheio à lógica econômica e social que condicionou seu desenvolvimento. Sob tal perspectiva, Rüdiger (2011) enveredou pela análise das mídias digitais por meio da crítica à economia da comunicação. Em um estudo que buscou compreender e sistematizar como o movimento de formação da cibercultura se articula reflexivamente no plano do pensamento teórico contemporâneo, o autor elaborou um rico panorama das diferentes correntes que se deitam sobre as relações entre o homem e as redes telemáticas. Rüdiger contesta linhas de análise calcadas no determinismo tecnológico porque, a seu ver, a técnica

\footnotetext{
é, antes de tudo, uma forma de saber que, como tal, existe sempre encarnada e, por isso, não pode ser separada de seu uso concreto, mesmo no momento de sua origem, visto que esta origem, segundo a tradição, é sempre o homem em condições históricas e sociais determinadas. ((RÜDIGER, 2011, p.64)
}

Rüdiger vai ao encontro de porta-vozes da perspectiva cibercriticista, como Steven Siegel e Julian Stallabrass, que observam que a cibercultura é controlada pelas forças do mercado. Segundo esses autores, explica Rüdiger, a ênfase mercadológica verificada na operação da mídia tradicional não é estranha às novas tecnologias de informação. Dessa forma, o fetichismo da mercadoria perdura na "promoção de um igualitarismo rebaixado a termos mercantis e que apenas se vale do nome da democracia" (idem, p.46). Portanto, a liberdade individual conferida às escolhas dos internautas seria, conforme esse ponto de vista, mera aparência construída em cima de padrões mercadológicos de busca por audiência.

Ratificando essas constatações, Rüdiger acrescenta que "a cibercultura não constitui em sua espinha dorsal e cotidiana senão um cenário avançado e high-tech da cultura de massas e da indústria cultural" (idem, 47). Para ele, a expansão da Internet não significou o fim dos conflitos sociais, das crises econômicas e da desorientação 
espiritual, pois ainda falta à cibercultura a capacidade de aperfeiçoamento moral e intelectual do ser humano. Com efeito, o processo de cultivo do ser humano promoveria uma civilização mais avançada, pacífica e equilibrada.

A teoria crítica capaz de discernir aspectos positivos e negativos da trajetória das novas tecnologias também foi cara a Rüdiger, que dialogou com os pesquisadores neomarxistas Douglas Kellner e Andrew Feenberg. Em seus estudos, Kellner salientou que a Internet é um terreno disputado pela esquerda, direita e centro que a usam para promover suas próprias agendas e interesses. Entretanto, considera que a disputa não anula o fato de que a lógica do capital é imperiosa e, deste modo, privilegia o objetivo do lucro. A materialização da tecnologia em lutas sociais também é um argumento visto em Feenberg, cujos textos influenciaram Kellner. Mesmo que o capitalismo tenha tornado a tecnologia um princípio de dominação política, resistências à técnica fazem parte do processo ambivalente de desenvolvimento social que semeia várias possibilidades.

Rüdiger entende que a cibercultura reproduz os antagonismos fundadores de nossa estrutura social, por isso não a restringe a meio comunicativo e objeto de discurso ideológico. Trata-se também de um cenário para a acumulação do capital e para as disputas sociais e econômicas. Apesar do evidente comando do mercado neoliberal capitalista que fortalece as elites econômicas e inibe a ação da classe trabalhadora, o desenvolvimento das novas tecnologias e práticas de informação "cria um novo campo de ação histórica concreta e transformadora para a sociedade" (RÜDIGER, 2011, p. 149).

Por situar-se em uma noção dialética da totalidade e suas mediações, o conceito de Indústria Cultural, elaborado por Adorno e Horkheimer na década de 1940, não pode ser esquecido. Ao pressupor a formação de um sistema de fabricação massiva de bens culturais, os teóricos da Escola de Frankfurt refutaram a ideia defendida por muitos estudiosos de que a sociedade chegara a um caos cultural. Segundo a dupla, a obra de arte deixou o terreno da autonomia criativa para submeter-se à condição de mercadoria em uma indústria controlada pelo poder econômico. A técnica, portanto, não foi isoladamente a propulsora desse fenômeno, e sim a função a ela atribuída na economia. "Por enquanto, a técnica da indústria cultural levou apenas à padronização e produção 
em série, sacrificando o que fazia a diferença entre a lógica da obra e a do sistema social” (ADORNO; HORKHEIMER 1985, p. 100).

A racionalidade técnica foi empregada como instrumento da dominação social na indústria da homogeneização cultural, que conduziu a arte aos negócios do entretenimento enquanto prolongamento da alienação do trabalho. Nesse sistema, os meios de comunicação de massa, na época o rádio e o cinema, foram elementos-chave na difusão de produtos culturais que sustentavam a lógica do capital. Alvos da profusão uniforme de conteúdos que divertem de maneira a afastar a crítica à realidade, os consumidores são classificados estatisticamente de acordo com critérios de rentabilidade. Sob esse viés, os produtos culturais emanam mensagens homogêneas e totalizam o mundo de modo a torná-lo uma coisa só, igualando o universal ao particular e vice-versa.

Bolaño (2000) recupera as regras de funcionamento da Indústria Cultural e verifica que a informação contribui para o cumprimento de duas funções elementares deste sistema de produção de bens culturais: a acumulação do capital e a reprodução ideológica do sistema. Quanto à primeira função, a informação acrescenta valor à mercadoria e rompe as barreiras de tempo e espaço, desempenhando neste aspecto papel semelhante ao dos meios de transporte e circulação. Atreladas umbilicalmente ao processo competitivo capitalista, as técnicas de fabricação de informação são continuamente expandidas e aperfeiçoadas.

\footnotetext{
É evidente que uma das características do desenvolvimento capitalista é a crescente sofisticação dos mecanismos de estocagem, manipulação e disseminação da informação e da telemática, fato que não se relaciona exclusivamente com as condições políticas e econômicas que podem influenciar a tomada de decisões, das condições climáticas, geográficas, etc. A expansão capitalista em âmbito mundial e o desenvolvimento de um sistema financeiro articulado internacionalmente exigem a expansão paralela dos sistemas de comunicações e transportes, como o próprio Marx já havia explicitado com precisão, como vimos anteriormente. (BOLAÑO, 2000, p. 47)
}

O espraiamento da produção chega à produção simbólica e abrange toda a classe trabalhadora, expandindo assim o corpo da sociedade do consumo. Instituição simbólica oficial das sociedades capitalistas, a Indústria Cultural adapta a produção cultural às condições gerais de produção. Segundo Bolaño, no pano de fundo desse processo, que se desenrola nas primeiras décadas do século $\mathrm{XX}$, ocorre a passagem ao capitalismo monopolista, a fase do sistema marcada pelo aumento da concentração e centralização 
do capital em blocos econômicos. A publicidade veiculada pelas mídias de massa tem um lugar fundamental nessa etapa do capitalismo, pois incide no aumento da mais-valia, abrevia a circulação da mercadoria, acelera a rotação do capital e reforça necessidades de consumo.

Assim, o apoderamento das tecnologias de comunicação pela classe dominante tem relação direta com a predominância de um modelo cultural e ideológico. Isso remete ao conceito de príncipe eletrônico formulado por Ianni (2000). O príncipe eletrônico, explica o autor, representa a visão de mundo predominante nos blocos de poder em escala local e global, ultrapassando dois príncipes dos tempos modernos: o príncipe descrito por Maquiavel e o moderno príncipe presente na obra de Gramsci. Segundo Ianni, o príncipe maquiavélico inaugura no século XVI o pensamento político moderno e representa uma figura política personalizada tomada como referência por muitos governantes e candidatos a governantes. A atuação bem-sucedida do príncipe depende da articulação entre dois fatores: a virtú - as habilidades de liderança - e a fortuna - as condições político-econômicas e sócio-culturais. Portanto, “o enigma do contraponto fortuna e virtú" consiste na capacidade do príncipe lidar com as circunstâncias adversas sem perder a soberania e a lealdade dos seus seguidores.

Em Gramsci, a teoria do moderno príncipe marcou o século XX com a conceituação do partido político como intérprete e condutor de indivíduos e coletividades, grupos e classes sociais. Criado no âmbito da sociedade de classes, o príncipe não é uma pessoa, mas um organismo que combina capacidades de líderes e seguidores; o intelectual coletivo capaz de interpretar filiados do partido e outros setores da sociedade. "O moderno príncipe se revela capaz de construir, realizar e desenvolver a hegemonia de um projeto de Estado-Nação, envolvendo a organização, o desenvolvimento ou a transformação da sociedade" (IANNI, 2000, p.142). Ianni associa o príncipe maquiavélico e o príncipe gramsciano, arquétipos ou tipos ideais pensados em diferentes contextos histórico-sociais, à capacidade de construir hegemonias e soberanias.

Secco (2006) considera o conceito de hegemonia desenvolvido por Gramsci o mais importante da teoria política marxista do século XX. Fruto de estudos sobre a história francesa e italiana do século XIX, o conceito não pode ser empregado como estratégia política fixa, pois só pode ser entendido a partir de estudos históricos e de análises de 
conjuntura. Secco sugere que a hegemonia seja entendida como um processo, e não adaptada de acordo com a pretensão de quem quiser instrumentalizá-lo. Segundo ele, a hegemonia é geralmente entendida como a

\begin{abstract}
"capacidade que uma classe, uma fração ou conjunto de frações de classe, um grupo social ou mesmo um partido tem de dirigir outros segmentos sociais e eventualmente oprimir ou liquidar aqueles que não aceitam pacificamente a sua direção" (SECCO, 2006, p. 43).
\end{abstract}

A hegemonia, segundo a interpretação de Secco, é um tipo de dominação predominantemente, e não integralmente, consensual, uma vez que a coerção daqueles que recusam a nova direção pode vir a ser necessária. Chauí (2006) assinala que conceito questiona "as relações de poder e a origem da obediência e da subordinação voluntárias (...)" (CHAUÍ, 2006, p. 23). Por hegemonia, a autora entende uma vontade coletiva para uma direção cultural e política específicas, visão alargada por Ianni ao definir a vontade coletiva como a união de interesses e tendências dos grupos sobre os quais a hegemonia será exercida. A vontade coletiva ${ }^{2}$, observa Secco, tem como finalidade a realização da necessidade histórica, que só existe quando a objetividade se transforma em "universal coletivo". Dos comentários dos autores sobre Gramsci, depreende-se que a vontade coletiva concebida pelo teórico italiano não se restringe a um projeto político e econômico, pois deve incorporar um movimento cultural. Secco evidencia o laço orgânico entre estrutura e superestrutura, formadoras do conceito gramsciano de bloco histórico.

\footnotetext{
"Um projeto de hegemonia nasce com o suporte objetivo no mundo da produção material, mas só se torna efetivo e possível vinculado a uma superestrutura cultural e ideológica, pois é nela que os homens tomam consciência dos conflitos estruturais" (SECCO, 2006, p.30).
}

Herdeiro de Gramsci, Williams incorporou a noção de hegemonia ao materialismo cultural e sustentou que a cultura dominante - sistema central e efetivo de significados, práticas e valores - não é simplesmente manipuladora das massas, sendo constantemente ameaçada por culturas residuais, como as tradições de um passado rural, e emergentes, como as experiências novas criadas constantemente.

Temos de deixar claro que a hegemonia não é algo unívoco; que, de fato, suas próprias estruturas internas são altamente complexas, e têm de ser renovadas, recriadas e defendidas continuamente; e que do mesmo modo elas podem ser continuamente desafiadas e em certos

\footnotetext{
${ }^{2}$ Secco nota que Gramsci via na vontade coletiva o cerne da União Soviética. Gramsci procurou na Itália o equivalente aos soviets, voltando seu olhar para os conselhos de operários formados em Turim. Para ele, a sociedade era extensão da fábrica, célula-máter de toda organização social e estatal.
} 
aspectos modificadas. É por isso que ao invés de falar simplesmente de "a hegemonia", ou em "uma hegemonia", eu proporia um modelo que permitisse a variação e a contradição, com seu conjunto de alternativas e processos de mudança. (WILLIAMS, 2005, p. 216)

A compreensão da hegemonia supera o antagonismo entre cultura e política e problematiza a luta de interesses na sociedade de classes. Secco esclarece que quando a luta pela conquista do poder está em questão, coloca-se o desafio de construção da hegemonia alternativa, "na qual se expressam as classes e os grupos sociais subalternos em luta para realizar sua vontade coletiva nacional-popular, alcançando a soberania" (SECCO, 2006; p. 146). Se a cultura é parte constitutiva do projeto de hegemonia, a utilização de meios de comunicação tem grande serventia na expressão da vontade coletiva. Entretanto, a apropriação das mídias pela classe dominante distancia o êxito de um projeto de hegemonia alternativa. Com o fenômeno da globalização do capitalismo no fim do século XX, a construção de uma nova hegemonia ficou ainda mais difícil, pois as categorias clássicas da política foram colocadas em causa e os jogos das forças sociais alteraram-se. Ianni indica que estamos diante de uma nova configuração histórico-social da vida, trabalho e cultura, na qual as sociedades civis nacionais revelam-se províncias da sociedade civil mundial em formação.

\footnotetext{
"Nessa época, as tecnologias eletrônicas, informáticas e cibernéticas impregnam crescente e generalizadamente todas as esferas da sociedade nacional e mundial; e de modo particularmente acentuando as estruturas de poder, as tecnoestruturas, os think tanks, os lobbies, as organizações multilaterais e as corporações transnacionais, sem esquecer as corporações da mídia" (IANNI, 2000, p.143)
}

Ianni constata o desenvolvimento predominante da mídia em tudo o que se refere à política. Da mesma forma que fortalecem as estruturas de poder em escala mundial, as tecnologias eletrônicas, informáticas e cibernéticas intensificam as tensões e os antagonismos. Nesse cenário emerge o príncipe eletrônico, que permeia todos os níveis da sociedade e torna-se o intelectual coletivo e orgânico dos blocos de poder. Embora expresse principalmente a visão dos blocos de poder dominantes, o príncipe eletrônico também abarca as perspectivas das classes subalternas, que o desafiam com visões alternativas a fim de democratizá-lo. Ianni aponta que as vozes que buscam transformar a sociedade muitas vezes vêm de especialistas ligados à mídia e à informática; segundo o autor, os usos que estes e outros profissionais fazem das técnicas aumentam as capacidades políticas, econômicas e culturais das técnicas sociais. 
Agente que combina produção e reprodução cultural com produção e reprodução do capital, o príncipe eletrônico transforma mercadoria em ideologia, mercado em democracia, consumo em cidadania. As corporações transnacionais, das quais grande parte da mídia participa, interessam-se pela expansão da convergência de mercado e publicidade, tornando-se agentes decisivos do modo como funcionam as novas tecnologias. Impõem interesses corporativos às instituições clássicas da política e dissolvem as fronteiras entre público e privado, mercado e cultura, cidadão e consumidor. A ágora eletrônica não se resume à espetacularização e estetização, porém, o ordenamento dos meios de comunicação pela Indústria Cultural compromete significativamente a emancipação social. Bolaño e Brittos (2007) atentam para as dificuldades de garantir o espaço igualitário simbolizado pelas redes:

\begin{abstract}
Esta divisão provoca uma cisão entre a imensa maioria da população mundial, excluída, e uma parcela que se integra, através desses novos meios, a uma espécie de espaço público globalizado que recupera, de alguma forma, marcada por enormes assimetrias internas, um caráter relativamente crítico e brutalmente restrito, semelhante ao da velha esfera pública burguesa, inclusive com os mesmos critérios de exclusão, capital simbólico e propriedade. (BOLAÑO; BRITTOS in SOARES et SANTOS, 2007, p. 93)
\end{abstract}

Em um artigo voltado especificamente para a economia política da Internet, Bolaño e Castañeda (2004) lembram que as redes digitais originaram-se em universidades norteamericanas no final dos anos 60 com fins militares. Progressivamente, o financiamento do governo e de fundações científicas deu lugar à lógica privada com a entrada de grandes companhias telefônicas, provedores de acesso e, consequentemente, da publicidade. O histórico da Internet, dizem os autores, estrutura o que Schiller ${ }^{3}$ denomina capitalismo digital, caracterizado pelo desenvolvimento das infraestruturas telemáticas em consonância com o das redes empresariais, "ligadas à evolução do capitalismo no período e à globalização, levando à transformação da economia mundial da qual a internet é elemento central” (BOLAÑO; CASTAÑEDA; 2004, p. 4). Essa operação traz mudanças significativas em todos os setores da economia das comunicações. Vendo as assimetrias e contradições inerentes ao capitalismo, Bolaños e Castañeda afirmam que a superação desses obstáculos pode se dar através de "políticas públicas ativas de democratização do acesso à rede" e da "socialização do capital cultural indispensável à apropriação massiva das novas tecnologias".

\footnotetext{
${ }^{3}$ SCHILLER, D. (1999). Capitalismo Digitale. Università Bocconi Editore, Milano, 2000.
} 
Após refletir sobre as condições reais e imaginadas para a realização da democracia, será analisada a atuação política apoiada em redes digitais. Quais as heranças e características do ativismo que ganhou visibilidade no ciberespaço desde o fim do século passado? Até que ponto as mobilizações difundidas em meio virtual empurram para a democratização da sociedade ou, mais radicalmente, para a luta anticapitalista? O tópico seguinte vai mostrar o que alguns autores dizem sobre o ciberativismo e as condições para a construção de uma mídia contra-hegemônica.

\title{
2.3- Análises sobre o ativismo em rede
}

O aumento da acessibilidade de computadores, redes e softwares fortaleceu a prática da mídia tática, ou seja, o uso diferenciado dessas ferramentas por ativistas em busca de transformações sociais e políticas. Aos poucos, movimentos sociais tradicionais repensaram suas estratégias de comunicação ao fazerem uso das redes digitais, que também foram aproveitadas por grupos desvinculados de partidos e sindicatos e com um perfil de atuação descentralizado e horizontal. Em comum, as mobilizações organizadas por esses movimentos têm a intenção de reivindicar o direito de participar diretamente na política, sem a mediação de instituições tradicionais, em escala local e global. Sua forma de organização traz as características da sociedade a ser construída com a conquista da autonomia.

Os limites do engajamento político potencializado no e pelo ciberespaço são frequentemente questionados. Considerando movimentos em que boa parte da articulação não se dá presencialmente, Gladwell ${ }^{4}$ diz que às redes sociais faltam a disciplina e a estratégia necessárias para a organização de um movimento com efeitos reais. Fazendo uma comparação ao movimento de negros pelos direitos civis nos Estados Unidos na década de 1960, Gladwell observa que o ativismo de alto risco é um fenômeno de vínculos fortes.

\begin{abstract}
As plataformas dessas redes são construídas em torno de vínculos fracos. O Twitter é uma forma de seguir (ou ser seguido por) pessoas que talvez nunca tenha encontrado cara a cara. O Facebook é uma ferramenta para administrar o seu elenco de conhecidos, para manter contato com pessoas das quais de outra forma você teria poucas notícias. É por isso que se pode ter mil "amigos" no Facebook, coisa impossível na vida real. (GLADWELL, Malcolm)
\end{abstract}

\footnotetext{
${ }^{4}$ Em artigo intitulado "A revolução não será tuitada". O ano de publicação não foi informado.
} 
Entretanto, a ausência de vínculos pode ser uma constatação apressada e simplista, pois muitas mobilizações já demonstraram profundidade em suas ações ao se firmarem também em espaços físicos. Talvez, a fraqueza que aparentam evidencia alterações nos formatos das mobilizações. Gohn (2010) identifica mudanças na ação coletiva que desencadeiam o alargamento das fronteiras e tensões sociais em virtude da nova geopolítica que a globalização econômica e cultural tem gerado:

\begin{abstract}
Resulta que a sociedade civil organizada passou a orientar suas ações coletivas e associações por outros eixos, focada menos em pressupostos ideológicos e políticos predominantes nos movimentos sociais dos anos 1970 e 1980 e mais nos vínculos sociais comunitários organizados segundo critérios de cor, raça, idade, gênero, habilidades e capacidades humanas. Dessas articulações surgem as redes sociais e temáticas organizadas segundo gênero, faixas etárias, questões ecológicas e socioambientais, étnicas, raciais, religiosas etc., além dos fóruns, conselhos, câmaras etc., que compõem o novo quadro do associativismo brasileiro. (Gohn, 2010, p.12).
\end{abstract}

Nas demandas das mobilizações organizadas em redes digitais, Gohn encontra multiplicidade e entrecruzamento de antigos e novos movimentos sociais. Questões pontuais circulam junto a questões mais amplas, sobressaindo-se em ambientes digitais e analógicos. Entre as mobilizações articuladas em redes digitais, observa-se a predominância de motivações diferentes daquelas que pautavam as revoluções operárias e revolucionárias no início do século passado. Desde a década de 1960 é possível notar a perda da exclusividade da categoria de classe como tema central dos movimentos sociais, quando grupos feministas, homossexuais, pacifistas e ambientalistas despontaram no cenário social e passaram a reivindicar mudanças de valores na sociedade e medidas concretas, em vez da tomada do poder. O modo de produção vigente entrou em metamorfose e consolidou o toyotismo e o neoliberalismo para fragmentar a sociedade e defender os interesses capitalistas. Novas vias de opressão estimularam focos de resistência à margem da política institucional, que nas últimas duas décadas têm se comunicado por meio de mídias digitais.

A relevância da ocupação de espaços físicos, das marchas e das reuniões presenciais não deve menosprezar as potencialidades oferecidas pela Internet, como o amplo alcance das ações que pode beneficiar o intercâmbio entre diversos movimentos em escala internacional. A troca de informações e experiências entre grupos é capaz de fortalecer a formação alianças e ecoar críticas e reivindicações. Segundo León (2001):

En el desarrollo concreto, há sido uma oportunidad para explorar respuestas prácticas a muchos de los retos y problemas que surgen al 
ingresar a este nuevo médio: establecimiento de espacios comunes para afirmar el sentido colectivo e incrementar la visibilidad; creación de bases de datos e interfaces para facilitar El manejo técnico; combinación de web com listas de correo eletrônico, para ampliar la difusión; diseño de sistemas de clasificación y busqueda; complementación de los ritmos diferenciados de production de las organizaciones; difusión de información de aquellas que aún no tienen sitio próprio; superación de problemas de las listas de intercambio, entre otros. (LEÓN et all, 2001, p. 208)

Dessas experiências oriundas da descentralização das redes, Di Felice intui a emergência de um novo protagonismo sociopolítico marcado pelo colaborativismo, cujo principal objetivo não é a disputa pelo poder, apesar de exercer pressão sobre o Estado.

\begin{abstract}
Esse tipo de ativismo midiático tem nas novas tecnologias de comunicação um instrumento valioso para fortalecimento das organizações, tanto local quanto globalmente, arrecadando fundos, coordenando campanhas e protestos, obtendo e difundindo informações, denúncias e petições. Em termos gerais, o ciberativismo refere-se a como utilizar a Internet para dar suporte a movimentos globais e a causas locais, utilizando as arquiteturas informativas da rede para difundir informação, promover a discussão coletiva de ideias e a proposição de ações, criando canais de participação (Di Felice, 2008, p. 7).
\end{abstract}

O autor comenta que o ciberativismo herda princípios do movimento cyberpunk, que preza o uso da mídia como forma de ativismo, e faz brotar uma nova cultura política que se choca com a tradição política ocidental. Segundo ele, esses movimentos não possuem ideologia, bandeiras partidárias e líderes. O acesso tecnocolaborativo dos ativistas às novas mídias aumenta ainda mais sua repercussão quando eles ocupam as ruas e registram a presença física em vídeos, imagens e textos que logo são compartilhados na web e contrastados com a cobertura das mídias massivas.

Conforme Di Felice, o ciberativismo está inserido num espectro maior de ativismo digital em rede englobado pelo netativismo, que enaltece uma identidade cidadã global e reivindica a democracia e a equidade social. Ele sustenta que as características interativas próprias da rede levam a considerar o ponto de vista do mundo em sua totalidade, favorecendo a difusão de uma cultura planetária e ecossistêmica. A arquitetura conectiva e interativa da rede acaba por dar a forma das mobilizações que se articulam na web, afirma o pesquisador italiano. Partindo da perspectiva reticular, ele observa a emergência de um novo tipo de social chamado por ele de ato conectivo, que consiste num ato não previsível envolvendo uma amálgama de atores humanos e nãohumanos. Aspectos marcantes do ato conectivo, as dimensões informativa e habitativa 
abarcam corpo, tecnologias e territorialidade em uma sinergia simultânea, sem um direcionamento externo.

É preciso tomar cuidado para não homogeneizar o ciberativismo, como se qualquer ação que empregue mídias digitais possa ser enquadrada de maneira simplista no perfil descrito por Di Felice. A escolha de uma única noção de ciberativismo ignoraria que aqueles que usam as mídias digitais para protestar fazem parte de um campo heterogêneo, do qual apenas uma parte se propõe a uma crítica declaradamente anticapitalista. Por isso, a possibilidade de uma relação íntima entre a arquitetura informativa das redes e a forma de atuação política não deve ser tomada como uma verdade generalizante. As características atribuídas ao ciberativismo como autonomia e horizontalidade não são necessariamente determinadas pelos meios de comunicação utilizados. Processos históricos ao longo do século XX fortaleceram a atuação política autônoma que se desenvolveu distante das instituições legítimas da democracia representativa. A postura radical desses grupos e indivíduos que constituem uma minoria gera um discurso que não valoriza mais a técnica do que o contato físico. É necessário cautela ao afirmar que o emprego da comunicação digital por esses ativistas os enquadra como ciberativistas, pois a denominação pode sugerir a ênfase na técnica, e não no conteúdo da ação. O capítulo seguinte vai mostrar o discurso de coletivos anticapitalistas contra a supervalorização da tecnologia.

A análise de Downing (2004) sobre a mídia radical faz uma contribuição relevante para esta discussão. Segundo ele, o conceito de mídia radical expressa uma visão alternativa às políticas, prioridades e perspectivas hegemônicas. Expressa também a urgência do ativismo da mídia diante dos bloqueios da expressão pública. Apesar de não apostar em uma fórmula infalível para distinguir uma mídia radical de uma mídia não radical, Downing argumenta que a mídia radical ferve caldeirões dos quais podem emergir mudanças positivas. Baseando-se em textos anarquistas socialistas, feministas marxistas e teóricos marxistas dissidentes, o autor define dois propósitos de mídia radical: um que expressa verticalmente a oposição à estrutura de poder e outro que busca obter horizontalmente apoio e solidariedade para construir uma rede de relações contrárias à ordem dominante.

Downing afirma que as mídias radicais mesclam formas de expressão das culturas populares e de oposição. Ele critica a distinção feita por Adorno entre cultura de massa, 
que sufocaria o espírito de questionamento, e a cultura popular, que conteria inerente potencial de oposição. Em concordância com Barbero, Downing atenta para as interpenetrações entre as duas categorias, uma vez que a indústria cultural explora elementos do repertório popular, gerando as noções de mestiçagem e hibridismo. A cultura de oposição não está alheia a essa mistura, pois resulta da apropriação cultural que as audiências fazem dos produtos culturais de massa. Portanto, a mídia radical é um fenômeno misto e não se encontra isolada. O produtor radical é a audiência que elabora e molda os produtos da mídia, libertando o termo audiência de sua bagagem puramente mercadológica. A domesticação da audiência é apenas o modo de apropriação do conteúdo da mídia pretendido pelos grandes empresários da mídia, enquanto que dos movimentos sociais deriva a audiência ativa e dinâmica.

O potencial de resistência aos padrões da ordem estabelecida está intrinsecamente ligado à noção de audiência ativa, uma postura de interlocução que atua na coarquitetura da produção cultural. Diferente da apropriação mercadológica do termo, a audiência ativa preza pela construção coletiva, principal pressuposto de um fenômeno que emergiria do campo alternativo de oposição, a mídia radical. É bom enfatizar que o caráter radical não é condição da esfera pública alternativa, pois nem tudo o que é alternativo contesta a raiz da existência do hegemônico.

O autor não vê no suporte técnico uma prerrogativa da mídia, pois a considera, sobretudo, uma forma de expressar sentidos e informações. Assim, uma emissora de rádio é tão mídia quanto uma tatuagem, o que as diferencia é a complexidade do seu funcionamento. Ele traça uma escala ascendente de mídias radicais segundo a complexidade logística, que vai do grafite, passando por cartazes e volantes até a formação de uma organização midiática autônoma. Para Downing, a mídia é a principal operadora da cultura, portanto capaz de manter e transformar a realidade social.

Compartilhar com discernimento a gama de questões que flagelam a vida social, tal como percebidas a partir de inúmeros pontos de vista, e compartilhar as possíveis soluções para elas, bem como a hilariedade das tolices que diariamente surgem em torno delas, é muito mais condizente com o potencial da mídia do que qualquer outra cultura contra-hegemônica, como um partido, um sindicato, um conselho. (DOWNING, 2004, p.53) 
A mídia radical alternativa caracteriza-se pela ênfase nas múltiplas realidades de opressão além da econômica, o que revela a influência do anarquismo ${ }^{5}$. Downing associa a mídia radical ao conceito de hegemonia cunhado por Gramsci. A atenção que o teórico italiano marxista repousa sobre a questão do domínio cultural respalda essa relação. Aos comunicadores ativistas, Downing compara os intelectuais que, segundo Gramsci, deveriam se integrar à classe trabalhadora para desenvolver uma ordem social justa e culturalmente superior. Essa visão do papel dos militantes atrela-se ao modelo de contrainformação, segundo o qual a mídia radical deve quebrar o silêncio, refutar as mentiras e fornecer a verdade. Downing observa que assim como os intelectuais que se portam de maneira autoritária fortalecem a hegemonia capitalista, os profissionais da mídia convencional também o fazem ao se autocensurarem.

Downing também recorre ao pensamento de James Scott segundo o qual um grupo social antagonista pode manifestar diferentes níveis de descontentamento num largo espectro entre a concórdia e a revolta. Logo, a comunicação simbólica - que Downing interpreta como mídia radical - não serve apenas a ambiciosos projetos revolucionários, mas também a estratégias microssubversivas. Downing constata uma relação de forte interdependência dialética entre a mídia radical e os movimentos sociais. Aos movimentos sociais, ele confere o papel de dar dinamismo ao processo político, uma vez que operam fora das estruturas partidárias - embora mantenham relação com um ou mais partidos políticos.

Downing retoma o conceito de esfera pública de Habermas ${ }^{6}$, sem cair na frequente equiparação com o conceito de democracia. Assim como fez Habermas, Downing atenta para os entraves impostos pelo regime dominante, desafiando ainda mais os movimentos sociais. A conversa pública dentro dos movimentos sociais, diz ele, "ainda é moldada segundo os poderosos estímulos das economias capitalistas, de ordens sociais racializadas e culturas patriarcais" (idem, p.65). Logo, a importância da mídia radical está na articulação e difusão das questões, análises e desafios dos movimentos. Outra função cumprida pela mídia radical nos movimentos é a de "reacender a chama

\footnotetext{
${ }^{5}$ Em oposição ao marxismo tradicional que aposta na revolução conduzida por um partido que tomaria o Estado, o anarquismo almeja uma sociedade igualitária por meio da substituição do governo por uma forma de cooperação não governamental entre indivíduos livres. A criação no presente das ideias e fatos do futuro está vinculada à máxima de que os meios afetam os fins, sustentando uma organização antiautoritária e horizontal movida pela ação direta.

${ }^{6}$ Downing se refere ao conceito já mencionado neste trabalho, que tratava da esfera de influência e do debate político para além dos limites das cortes. Nessas zonas de discussão, cujo caráter racional é evidenciado por Habermas, a comunicação e a informação tinham papel crucial.
} 
mnemônica", ou seja, de recontar a história e reconstruir a memória coletiva. Mas, para que esse papel seja cumprido com eficácia, o autor indica a necessidade de uma comunicação lateral entre os movimentos, acabando assim com as rivalidades e fortalecendo a luta contra a hegemonia da estrutura de poder. ${ }^{7}$

Para Downing, as redes de comunicação interpessoal - que alimentam a mídia e são alimentadas por ela - são o elo que conecta o movimento social à mídia radical e constituem a dimensão primária do movimento. Ao explicar a centralidade desse processo, o autor questiona a característica racional conferida por Habermas ao debate público e afirma que a esfera pública "deixa de ser meramente uma ágora idealizada para tornar-se algo tangível entre membros de círculos interligados, cuja comunicação mútua faz com que se relacionem em muitos níveis, não apenas no debate racional e metódico" (DOWNING, 2004, p.70).

Ao enfatizar que a mídia radical contribui para a democratização da comunicação, Downing apropria-se da noção de poder de desenvolvimento, formulada por Macpherson para designar a oportunidade de usar e desenvolver capacidades. O poder de desenvolvimento está na base da democracia e "representa as possibilidades positivas de realização humana inerentes à vida social cooperativa, as quais, até o presente momento, têm sido deixadas de lado na construção da vida econômica e política" (idem, p.80). No entanto, a potencialidade de criar arranjos sociais duráveis é emperrada por vários obstáculos, como a falta de acesso aos meios de produção. Logo, a existência de estruturas formais de democracia não é suficiente para se consolidar a democracia. A cultura democrática é essencial para energizar os movimentos sociais e as mídias radicais, pois colabora para a formação de um cenário favorável ao florescimento do poder de desenvolvimento. Downing conclui que a mídia radical serve como agente do poder de desenvolvimento porque expande o âmbito das informações, da reflexão e da troca a partir dos limites hegemônicos.

Os objetivos da mídia radical não são os únicos elementos considerados importantes pelo autor. Downing também dá ênfase à forma de organização interna da mídia radical. Para melhor contextualizar, ele apresenta e discute, ainda que brevemente, dois modelos de organização. O primeiro é o leninista que, segundo o olhar crítico do autor, servia à

\footnotetext{
${ }^{7}$ Com esse pensamento, Downing não quer ignorar o pluralismo da esquerda, o qual sustenta empregando o conceito de contraesferas públicas da feminista Nancy Fraser, mas reforçar a urgência da integração.
} 
elite do partido soviético e era venerado na cultura do partido comunista internacional como a forma científica e definitiva da mídia pré e pós-revolucionária. Originou-se na época do regime czarista, na Rússia pré-revolucionária, quando os militantes se sentiam obrigados a atuar na clandestinidade e a estabelecer uma disciplina organizacional para fugir da repressão. O modelo caracteriza-se pela adoção do "agitprop" como uma combinação de táticas que utilizaria a arte e a comunicação para difundir projetos políticos e problemas imediatos ao resto da sociedade e persuadir setores populares a aderir à revolução. Porém, esse modelo de agitação e propaganda, assim que o partido bolchevique tomou o poder, foi acusado de suspender a autonomia dos artistas, comunicadores e intelectuais, atrelando-os instrumentalmente aos interesses do partido. Embora identifique aspectos manipuladores na agitprop ${ }^{8}$ como foi executada pela União Soviética, Downing observa que essa ferramenta de propagação gera um dinamismo positivo dos movimentos que se desenvolveram em favor da mudança. $O$ autor considera possível um trabalho de agitação comunicativa fora da fórmula rígida voltada para a mudança global unificada.

Para contrabalancear e talvez sugerir uma fusão, Downing expõe um segundo modelo de organização, fundado na tradição da autogestão. Nascido no seio do anarquismo, o modelo não aceitava a apropriação do veículo de comunicação por um partido ou sindicato. O veículo pertencia ao próprio jornal, estação de rádio, site de internet, etc. Seguidor da política pré-figurativa, o modelo autônomo tentava praticar os princípios socialistas no presente em vez de imaginar o futuro. A pretensão de um movimento internamente democrático, para Downing, não garante que as opiniões de todo o público sejam expressas. E acrescenta que "para que a mídia assim gerida evidencie um caráter plenamente democrático, é vital que sua democracia interna seja uma resposta constante às tendências e aos movimentos democráticos da sociedade em geral" (idem, p.114). O autor ressalta que a estrutura autônoma pode ser uma estratégia para as alternativas radicais, contudo adverte que esse modelo também padece de críticas, pois pode camuflar práticas autoritárias entre os membros da equipe supostamente igualitária.

Este trabalho vem tentando mostrar que o ativismo não deve ser homogeneizado nem esvaziado de suas características ideológicas. A definição de mídia radical ajuda a

\footnotetext{
${ }^{8}$ A cartilha "Agitação e Propaganda no Processo de Transformação Social", elaborado pelos Coletivos de Comunicação, Cultura e Juventude da Via Campesina, mostra uma intepretação apartidária do modelo de agitprop. Disponível em http://culturamess.files.wordpress.com/2012/01/caderno-de-agitprop.pdf.
} 
sustentar a hipótese de que as tecnologias digitais não moldam por si só o ativismo articulado em rede nem determinam seu objetivo contra-hegemônico, por isso as interpretações sobre a esfera pública contemporânea e as potencialidades democráticas tiveram que ser aprofundadas com uma discussão acerca das pressões que a estrutura hegemônica exerce sobre a Internet e outros meios de comunicação. A fim de tocar em um aspecto ainda não abordado do vínculo entre ativismo e novas tecnologias, o tópico seguinte vai analisar as mudanças no modo de exploração do trabalho a partir de uma leitura crítica sobre o trabalho imaterial.

\section{4- Hipótese sobre a hegemonia do trabalho imaterial}

$\mathrm{Na}$ transição do fordismo ao pós-fordismo, deu-se a reestruturação capitalista com o apoio de uma alta tecnologia desenvolvida para desempenhar um papel essencial no comando cibernético. "Se a automação dizimou a base fabril do operário massa, as telecomunicações permitiram às grandes empresas globalizarem sua busca de mão de obra e obter regulações mais frouxas" (ALTAMIRA, 2008; p.73). A inauguração do toyotismo como o modo de produção oficial do neoliberalismo em uma sociedade globalizada na qual a privatização e a desregulação eram - e ainda são - os elementoschave fundou uma nova lógica de dominação e fragmentação social. Os movimentos sociais dispersaram e o poder dos sindicatos junto ao Estado interventor foi reduzido. As políticas social-democratas deram lugar à liberalização do mercado sem as mãos do governo. Conforme Altamira:

\footnotetext{
Os dispositivos de microeletrônica e de comunicação inicialmente projetados para desempenhar funções militares contra o inimigo externo na década de 1950 foram endocolonizados, para usar uma expressão de Paul Virilio (1980), com o objetivo de derrotar o inimigo interno fabril. (ALTAMIRA, 2008, p. 74)
}

Reflexo dessa nova dinâmica foi o Consenso de Washington, evento que em 1989 reuniu o governo norte-americano, o Fundo Monetário Internacional, o Banco Interamericano de Desenvolvimento e o Banco Mundial para avaliar as políticas econômicas dos países latino-americanos. O objetivo da reunião era homogeneizar as medidas econômicas na América Latina a fim de adequá-las ao escopo neoliberal encabeçado pelos Estados Unidos. Institucionalizava-se o pensamento de que o Estado deveria intervir minimamente nos assuntos econômicos, ficando a cargo dos organismos internacionais a regulação da economia. Com isso, a liberalização abriria os mercados domésticos dos países subdesenvolvidos para o capital estrangeiro, deixando setores 
como educação e saúde desassistidos. Em um mundo sem União Soviética, a economia de mercado entraria em vigência como a única realidade possível.

A constituição de uma sociedade informatizada, mas não menos capitalista, fundamenta a hipótese de que o trabalho imaterial tornou-se dominante. Negri, um dos principais defensores dessa ideia ${ }^{9}$, identifica a centralidade de um trabalho vivo cada vez mais intelectualizado e qualitativamente generalizado. Conforme tal percepção, "o ciclo do trabalho imaterial ocupa um papel estratégico na organização global da produção". (LAZZARATO; NEGRI; 2001, p. 26). Isso se deve, segundo ele, à pregnância das redes informáticas e telemáticas em todas as atividades humanas que compõem o ciclo da produção e organização do trabalho. Negri explica que a emergência da sociedade pósfordista foi condicionada pela transformação integral do trabalho em trabalho imaterial e da força de trabalho em intelectualidade massa. A intelectualidade de massa, ele diz, tem o potencial de se tornar um "sujeito social e politicamente dominante" (idem, 27).

De acordo com Negri, a pressuposição de que o trabalho imaterial tornou-se hegemônico relaciona-se ativamente com o ponto de vista marxista. Embora esta pesquisa não tenha o intento de esmiuçar a obra de Marx, é interessante mencionar que a teoria do trabalho imaterial mostra ser um desdobramento do trecho sobre o "Fragmento das máquinas" presente nos Grundrisse, em que o filósofo alemão desenvolve hipóteses sobre a forma de trabalho no futuro do desenvolvimento capitalista. "Tal hipótese prevê que o trabalho se torne cada vez mais imaterial, isto é, dependa fundamentalmente das energias intelectuais e científicas que o constituem" (NEGRI, 2003, p. 92). Negri ratifica a pretensão de manter o trabalho no "seu quadro criativo de ser e de história" (idem, p. 99) e coloca que a mudança no quadro paradigmático estabelece apenas que o trabalho muda e se torna sempre mais cognitivo. "Outro elemento fundamental, do ponto de vista da continuidade com o pensamento marxista, é que esse trabalho permanece, em nossa experiência, como trabalho explorado" (ibidem)

\footnotetext{
9 É importante lembrar que o pensamento de Negri muito se deve à sua participação no operaísmo italiano, movimento que na década de 1960 defendeu o autonomismo, uma forma de atuação política independente de instituições mediadoras, considerando que a classe trabalhadora também era feita de lutas fora da indústria.
} 
Cocco $^{10}$ corrobora com a hipótese afirmando que as dimensões produtivas das novas figuras sociais centrais não são dependentes da inserção na relação salarial. Por sua vez, Altamira supõe que a crença no fim do trabalho por alguns teóricos na verdade trata-se da redução do trabalho fabril, à maneira capitalista, a partir da reestruturação e reorganização dos processos produtivos. O equívoco cometido pelos teóricos do fim do trabalho, comenta o autor, foi não considerar a característica imaterial do trabalho vigente na atual fase do capitalismo, na qual "o trabalho industrial - como trabalho imediato - se transforma em um elemento secundário na organização capitalista", (ALTAMIRA, 2008, p. 64).

Os trabalhadores imateriais, centrais na produção capitalista, coexistem com aqueles provenientes do trabalho precário característico do novo século, formando novas dimensões políticas das lutas. Na atual configuração do trabalho há uma elite composta pelos trabalhadores do setor high tech, extremamente qualificados e dotados de altos salários. Ao lado deles, estão os trabalhadores desqualificados, mal pagos e socialmente desprotegidos que atuam "fundamentalmente nos setor de serviços e trabalhos domésticos caracterizados por um alto grau de informalização, precarização e sazonalidade características de uma força de trabalho "sem garantias"” (ALTAMIRA, 2008, p. 54). Depreende-se, portanto, que a desqualificação antes exclusiva dos trabalhadores industriais da fase fordista virou marca do trabalho precarizado do terceiro milênio. Embora carregue muitos aspectos do modelo passado, o trabalho fragmentou-se, o que dificulta a distinção clara do proletariado e da burguesia, classes que no século XX apresentavam-se como blocos homogêneos facilmente identificáveis. Cocco complementa que:

\footnotetext{
"A explosão da informalidade e de toda forma de precarização do trabalho (e da vida) acontece em uma situação de ausência de um verdadeiro sistema Welfare, e pois, dos diversos dispositivos de cobertura social dos quais os trabalhadores precários podem dispor na Europa Ocidental (e também, embora em menor medida, nos EUA)" (LAZZARATO; NEGRI; 2008, p.11).
}

O toyotismo organizou as empresas de uma maneira flexível segundo a qual um pequeno núcleo de empregados permanentes está rodeado de empregados periféricos em regime de subcontratação. Para Negri, reconhecer a hegemonia do trabalho imaterial

\footnotetext{
${ }^{10}$ As citações de Cocco referem-se à introdução que ele escreveu no livro de Lazzarato e Negri (2001), entre as páginas 7 e 23 .
} 
não significa ignorar a "subordinação destes espaços de autonomia e organização do trabalho imaterial às grandes indústrias (processos de recentralização) no curso da fase de reestruturação sucessiva (emergência do modo de produção pós-fordista)" (idem, p. 27). Por isso é importante sublinhar que a tese do teórico italiano consiste na constatação de uma hegemonia do trabalho imaterial, e não de uma exclusividade que eliminaria a existência do trabalho industrial.

Da detecção da ampliação fragmentária da classe trabalhadora decorre a observação de outro aspecto relevante da sociedade atual, além da progressiva mercantilização da vida humana: o espraiamento do espaço industrial para o resto da sociedade. O trabalhador social, ou indivíduo social, é o grande pilar da sustentação da produção e da riqueza do que o autonomismo chama de fábrica difusa, caracterizada por operações desterritorializadas, dispersas e descentralizadas pelo uso ostensivo das tecnologias da informação. Assim, a detecção feita pelo operaísmo na década de 1960 de uma multiplicidade de sujeitos pertencentes direta e indiretamente à classe trabalhadora reforça-se e adquire novos rumos. O mundo seria uma grande fábrica social onde o trabalho ultrapassa paredes e passa a ocupar "um lugar adequado às novas funções de atividade produtiva concentrada e sua transformação em valor”. (ALTAMIRA, 2008, p.75)

Segundo a teoria da hegemonia do trabalho imaterial, a comunicação e a informação cumprem papel essencial na composição da sociedade de hoje, pois o trabalhador imaterial é o fruto da constante relação entre a produção tecno-científica e o setor duro de produção de mercadorias. O estreitamento do vínculo entre processos produtivos e processos comunicativos resulta em novas formas de exploração, uma vez que a criação de uma extensa rede de computadores interconectados foi uma resposta do capitalismo às tensões insufladas pelos movimentos de contracultura, reação que soube empregar as tecnologias para subordinar a sociedade ao regime e quebrar a resistência dos trabalhadores. Conclusão desse raciocínio: as operações tecnológicas e comunicativas moldam a produção e a distribuição de bens e serviços, estando o trabalho imediato relegado a uma função secundária. Essa dinâmica tendencialmente imaterial recebe o nome, pelos teóricos citados neste tópico, de "cooperação".

O termo cooperação confere autonomia à força de trabalho que constitui o ciclo produtivo imaterial, como se o trabalhador fosse capaz de organizar o próprio trabalho e 
as próprias relações com a empresa. Negri utiliza o conceito de interface, comum entre os sociólogos da comunicação, para explicar autonomia da atividade do operário social. Ao mesmo tempo em que a execução de uma atividade abstrata foi um jeito de capturar a criatividade expressa pelos trabalhadores no século que passou, também fez valer o modelo de trabalho que permite ao funcionário uma interface "entre diferentes funções, entre as diversas equipes e entre os níveis de hierarquia (LAZZARATO; NEGRI, 2001). Essa carga de subjetividade independente da organização capitalista, segundo Negri, é potencialmente transformadora porque vem da história de luta contra o trabalho. A nova natureza do trabalho possibilitou a junção da concepção com a execução, diferente do modelo taylorista que separava as duas etapas, e "promoveu a relocalização e revalorização da capacidade do trabalhador em comandar a cooperação social produtiva" (ALTAMIRA, 2008, p.55).

A originalidade do capitalismo cognitivo, caracterizado pela hegemonia do trabalho imaterial, está em captar de forma generalizada "os elementos inovadores que produzem valor" (NEGRI, 2003, p. 94). O capital perde o comando sobre o instrumento de trabalho quando este é reapropriado pelo cérebro humano. Interpretando a cooperação do trabalho imaterial como uma potência produzida pela ação crítica e libertadora contra “o poder parasitário dos patrões", Negri aponta para a indistinção entre tempo produtivo e tempo de lazer. Em um excerto passível de críticas, que virão adiante, ele afirma que o trabalho necessário da sociedade foi reduzido "a um mínimo, ao qual correspondem, em seguida, a formação e o desenvolvimento artístico, científico etc. dos indivíduos graças ao tempo que se tornou livre e aos meios criados por todos eles" (LAZZARATO; NEGRI; 2001, p. 29).

A abundância de recursos comunicacionais na atual fase do capitalismo alimenta o desenvolvimento do trabalhador imaterial e um campo permanente de tensões pelo controle desses mesmos recursos. A disputa material e simbólica pela revolução científica e técnica é um ponto friccional de questionamento do comando e do controle do capital em uma zona conflitiva que advém da potencialização da natureza social cooperativa do trabalho, intensificada pela textura comunicacional das sociedades modernas (ALTAMIRA, 2008, p. 83). Para Negri e Lazzarato, a política da comunicação e/ou a luta para a libertação do sujeito da comunicação substituiu o período anterior de organização do poder descrito pela representação política, sendo este por sua vez antecedido pela ordem da política clássica (mais classista e rígida). Segundo 
eles, "o tornar-se revolucionário dos sujeitos é o antagonismo constitutivo da comunicação contra a dimensão controlada da própria comunicação, isto é, que libera as máquinas de subjetivação de que o real é hoje constituído" (LAZZARATO; NEGRI; 2001, p.40).

Ao reportar-se ao pensamento de Negri, Altamira afirma que o teórico italiano não intui restringir os trabalhadores imateriais a um pequeno grupo de funcionários altamente especializados no conhecimento tecnológico. O que se propõe é a consideração de "uma força de trabalho generalizada que começa a ser requerida por um sistema que está, por sua vez, imerso na tecnociência" (ALTAMIRA, 2008, p. 82). Segundo Altamira, o nível de imersão do trabalhador do século XXI no mundo tecnológico é tão alto que aumentam as chances de uma apropriação subversiva. Entretanto, é dever desta pesquisa enfatizar o desequilíbrio da imersão nesses ambientes em países em desenvolvimento como o Brasil, onde a exclusão digital e o analfabetismo digital ainda são problemas a serem minimizados.

A conceituação do trabalho imaterial elaborada por Negri caminhou para uma reflexão voltada para o poder dominante e o contrapoder potencializado pela produção de subjetividade. Ele denomina a ordem social globalizada em que vivemos de Império, um sujeito soberano único que reverbera as contradições da democracia capitalista neoliberal, cuja matriz conflitual reside na transição ao trabalho imaterial, criadora de um contrapoder constituinte que embasa o conceito de multidão. O Império representa a atual força do desenvolvimento capitalista porque assumiu os poderes dos Estados Nação e passou a reger uma sociedade global de hierarquias e fronteiras imateriais governadas por instituições supranacionais. Assim, o Império está acima dos Estados e revela as dinâmicas conflituosas do processo que tem na globalização e na democracia os elementos centrais do discurso soberano oficial. Enquanto a esquerda considera o enfraquecimento do Estado prejudicial à democracia, a democracia capitalista tem uma visão otimista, afinal, a globalização concentrada dos mercados só tem expandido a economia capitalista. Em suma, o Império "compreende em sua lógica todas as três formas clássicas ou níveis de governo: a monarquia, a aristocracia e a democracia" (NEGRI, 2003, p. 117).

A democracia praticada pelo Império, afirma Negri, é falsa, pois as instituições neoliberais tomam decisões que priorizam o econômico em detrimento do político, 
tornando o sistema imperial a forma contemporânea de repressão da vontade de potência da multidão. O não exercício do conceito moderno de democracia como representação popular refletiu na construção de movimentos antiglobalização na virada do século, que serão abordados no próximo capítulo. A participação direta na política estava entre as reivindicações dos ativistas que se organizaram de maneira autônoma e horizontal diante da ineficácia das entidades representativas como partidos e sindicatos. Para dar conta da complexidade que essa realidade apresenta, Negri recorre ao conceito de biopoder trabalhado por Foucault. Negri explica que o biopoder, conforme a acepção foucaultiana, é o comando do Estado sobre a vida por meio de tecnologias e dispositivos de poder. Suscetível a esse controle que busca garantir a ordenação da sociedade melhorando a gestão da força do trabalho, estaria um conjunto de indivíduos com traços biológicos particulares. A forma coletiva de abarcar o trabalho, o imaginário e a vida diferencia o controle da disciplina, aquela forma de governo dada na fase fordistataylorista que agia sobre as pessoas singular e repetitivamente. Hoje, o biopoder parte de uma instância global, e às vezes virtual, pois não está mais inscrito entre os muros do Estado nacional.

Negri pontua que os estudiosos de Foucault chamaram o lado oposto do biopoder de biopolítica. A biopolítica define-se pela análise crítica que parte de baixo, das experiências de subjetivação e de liberdade. Extensão da luta de classes, a biopolítica está inerente ao modo de produção atual gerador da hegemonia do trabalho imaterial e do trabalho vivo cooperativo. O sujeito da biopolítica é a multidão, conceito bem distante da noção de povo, que se refere a um corpo social único e homogêneo, produto de um contrato violento escrito pela burguesia. Negri lembra que o conceito de multidão surge com maior pregnância na obra de Espinoza, que a definia como uma multiplicidade de singularidades situadas em alguma ordem. Antes de Espinoza, o significado de multidão era predominantemente negativo, como um mar de sujeitos desordenados.

Com a mudança de perspectiva, a multidão passa a decorrer da interação das singularidades que expressa uma vontade comum autônoma através da democracia. Essa vontade unânime dá origem ao conceito de comum, elemento que une a multidão por trás de identidades e diferenças, que a direciona em busca de uma forma política que não seja a da representação, aquela que aliena as potências dos cidadãos em favor do soberano. O comum manifesta-se na proliferação de atividades criativas, relações ou 
formas associativas diferentes. Negri enaltece a multidão como potência democrática, combinação de liberdade e trabalho imaterial que produz o comum. As subjetividades particulares da multidão se definem pelo trabalho imaterial que é capaz de executar e pela consequente potência de reapropriação da produção.

\footnotetext{
"Falamos antes de mais nada em multidão como conjunto, como uma multiplicidade de subjetividades, ou melhor, de singularidades; em segundo lugar, falamos em multidão como classe social não-operária (exemplar, nesse caso, é a experiência da transformação do trabalho na passagem do fordismo ao pós-fordismo, da hegemonia do trabalho material à do trabalho imaterial” (NEGRI, 2003, p. 145)
}

A multidão, nas palavras de Negri, é uma multiplicidade indefinida e imensurável, não representável e dotada de uma capacidade de cooperação. Incrustado na multidão, o antipoder compõe-se de resistência, insurreição e poder constituinte, três elementos internamente interligados e simultâneos. Negri ressalta que a resistência precisa ocorrer em atos coletivos para que consiga ser uma arma política poderosa com o potencial de transformar as estruturas de poder. A insurreição é um gesto coletivo de revolta em meio à guerra de dominados contra dominante em uma sociedade global ilimitada. Não se trata da insurreição à moda comunista moderna, pois a vitória sobre o Império não deve significar o aprisionamento em uma alternância de guerra nacional e guerra internacional nem na constituição de um novo poder em forma de Estado (NEGRI, 2003, p. 129).

Negri questiona a compreensão no pensamento tradicional comunista de que a multidão só pode expressar-se quando destruir o soberano, isto é, o Estado, para assim poder instaurar a ditadura do proletariado. A crítica considera equivocada tal saída, pois mantém-se a forma Estado, mesmo que de maneira invertida. Ao contrário, Negri sustenta que o governo proletário não é condição de um processo revolucionário. $\mathrm{O}$ Estado burguês, na verdade, seria um obstáculo para a multidão. As condições de insurreição não são mais cristalizadas como eram durante a Guerra Fria, conflito que submetia todos os movimentos a sua bipolaridade. Portanto, a multidão unifica os momentos de resistência, insurreição e poder constituinte, e possui mecanismos de formação de alguma forma análogos aos do Império, “em sua absoluta diferença e em sua absoluta oposição" (idem, p.153). Ambos não têm lugar. Negri acrescenta que a multidão nega o poder de soberania do Império, nega a relação entre quem comanda e quem obedece. 


\subsection{1- Críticas e ponderações}

Extrair da hipótese da hegemonia do trabalho imaterial os elementos relevantes para a análise do objeto de pesquisa em questão requer a ponderação tanto de determinadas colocações registradas acima quanto das críticas feitas por outros autores. Logo nas primeiras linhas de um artigo publicado em uma revista de sociologia, Lessa (2001) adianta que a tese do trabalho imaterial não resiste a um exame acurado. Partindo da acepção marxiana de que o trabalho cerebral e o trabalho das mãos estão juntos no processo de trabalho, Lessa afirma que a atividade cerebral só é possível com a transformação da natureza operada pelas "mãos", pois "o indivíduo e a sociedade que apenas pensassem ou preparassem as objetivações que transformam a natureza não produziriam os bens materiais indispensáveis à sua reprodução" (LESSA, 2001, p.4).

Ele sustenta que o crescimento do setor de serviços e das atividades preparatórias dos atos de trabalho não significa que as atividades de transformação da natureza tenham perdido a hegemonia. $\mathrm{O}$ fato, segundo o autor, é que o desenvolvimento das capacidades humanas e o afastamento das barreiras naturais provocaram a diminuição do intercâmbio orgânico com a natureza, permitindo a expansão de outras atividades que também foram apropriadas pelo processo de autovalorização do capital, isto é, a conversão dessas atividades em mais valia. Apesar disso, a força de trabalho que não opera a produção do conteúdo material da riqueza continua a depender desta.

\footnotetext{
O fato de o capital converter em fonte de lucro não apenas o intercâmbio orgânico com a natureza, mas também toda uma enorme série de outras atividades humanas, é a demonstração da enorme capacidade de generalização do capital a todas as esferas sociais, a incrível capacidade de o capital converter em meio de sua valorização as mais diferentes atividades humanas - mas isso não significa, de modo algum, o cancelamento do trabalho intercâmbio orgânico com a natureza como categoria fundante do mundo dos homens (LESSA, 2001, p.5)
}

Lessa critica a formulação desenvolvida por Negri e Hardt que opera o cancelamento da divisão entre "cérebro" e mãos (aspas do autor). Segundo ele, os autores identificam indevidamente a atividade intelectual ou improdutiva com a atividade de transformação da natureza nos bens imprescindíveis para a reprodução social, além de também erroneamente igualarem produção, consumo e circulação, “com o que se elimina a tese marxiana do trabalho enquanto categoria fundante do mundo dos homens" (idem). Lessa justifica sua crítica lembrando que o início da era das revoluções socialistas, no século XIX, sinalizou a entrada do homem em antagonismo com sua dimensão 
mercantil porque as necessidades e possibilidades criadas historicamente pelo homem estão em profunda contradição com as necessidades e possibilidades produzidas pela autovalorização do capital. Dessa forma, Lessa afirma que Negri e companhia erram ao igualar o trabalho produtor de mais-valia que inclui tanto a atividade material quanto a imaterial ao trabalho transformador da natureza, considerado por Marx a eterna necessidade da vida humana. Segundo Lessa, os dois conceitos se interpenetram, mas nunca se igualam.

Lessa se nega a aceitar a hipótese levantada por Negri e Hardt de que a reestruturação capitalista nos anos 1970 e 1980 foi uma resposta à luta dos trabalhadores contra o regime fordista. Segundo a leitura que o autor faz do italiano, foi um equívoco ainda maior afirmar que a vitória da multidão sobre o Império se dará em uma transição pacífica que conseguirá construir o comunismo no interior do capitalismo. Tal erro resulta, segundo Lessa, no cancelamento das classes sociais tal como concebidas por Marx e a generalização das unidades produtivas a todo o tecido social. A equiparação da produção ao consumo (ou fruição) superaria a alienação capitalista, segundo a interpretação feita por Lessa. E prossegue a crítica:

"Se quisermos ser sintéticos, trabalho imaterial nada mais é que um
trabalho que não tem na objetivação seu momento essencial. Por isso
ele pode desprezar de forma absoluta as distinções ontológicas entre
as diferentes objetivações! É por isso que, para eles, a atividade do
operário que transforma a natureza nos bens necessários à reprodução
social cumpre a mesma função social do consumidor que compra uma
calça, ou de um capitalista que transfere seu capital de um fundo de
investimento à bolsa de valores ou, finalmente, de um "marqueteiro"
que bola uma nova campanha publicitária. Ir ao cinema e converter
minério de ferro em chapas de aço são, para eles, rigorosamente a
mesma coisa no sentido da "produção": tudo se dissolve na
"imaterialidade" do trabalho pós-fordista" (LESSA, 2001, p. 14)

Lessa conclui que o pensamento desse teórico trata-se de um idealismo pós-moderno. Embora, de acordo com a perspectiva marxiana, as ideias tenham força material porque são mediadas por indivíduos concretos, Lessa reforça que é errôneo confundir o pensamento com a transformação do mundo objetivo, a preparação do trabalho com sua realização, a concepção de um produto com sua produção. Para ratificar essa posição, ele dá como exemplo a produção de um machado: "o machado é a síntese, operada pela objetivação, entre o projeto idealizado do machado e a transformação daquela pedra e daquela madeira naquele machado" (idem, p. 13). Mesmo reconhecendo a ocorrência de um rearranjo das atividades e das profissões no interior dos processos de produção ou de realização da mais-valia, Lessa insiste que não pode ser anulada a diferenciação 
ontológica entre o trabalho produtivo e o improdutivo. Para o autor, a transformação pela qual o mundo passa acontece em tal velocidade que dificulta a manutenção de qualquer previsão teórica. Essas mudanças, que atingem tanto o chão de fábrica quanto a composição orgânica do capital, fazem surgir novas formas de articulação entre trabalho produtivo e trabalho improdutivo. "Razoável afirmar, portanto, que a conformação das classes sociais tem se alterado, abrindo com isso consequências inesperadas para as lutas de classe e, muito evidentemente, para a política" (ibidem; p. $15)$.

Fernando Paz, cuja crítica se assemelha à crítica de Lessa, afirma em artigo publicado no site Passa Palavra ${ }^{11}$ que o conceito de trabalho imaterial não possui uma utilidade prática para transformar o mundo, pois supõe a existência de um comunismo sem derrubar o controle dos processos produtivos nas mãos dos capitalistas. A leitura única da conjuntura global, como se esta fosse homogênea, realizada na obra de Negri e Hardt também é criticada por Paz. A ideia de um mundo globalizado onde não há centro nem periferia permite a formulação de uma única estratégia política que tem na reestruturação capitalista um espaço fecundo para a luta pelo comunismo. Segundo Paz, Negri não vê que "a reestruturação e a re-configuração que aprofunda a extração de mais-valia é a mesma que distancia os trabalhadores das organizações classistas - alvos constantes das contra-reformas neoliberais" (PAZ, 2009). As mudanças ocorridas nas últimas décadas não têm alimentado uma potência revolucionária, mas, ao contrário, têm dificultado a articulação das lutas. Os trabalhadores, cada vez mais precarizados, continuam a reivindicar os velhos direitos e se afastaram das entidades representativas, que perderam legitimidade ao serem cooptadas pelo Estado.

Outro aspecto que incomoda na estratégia política abordada por Negri é a ausência da proposição de táticas para atingir a estratégia final do projeto político contrahegemônico. “A transformação que nos interessa não é a que está em curso. Negri não aposta suas fichas na propaganda teórica do socialismo libertário, nem na difusão de práticas revolucionárias e ações diretas de resistência e exigências contra o capital" (PAZ, 2009). O silêncio de Negri sobre essa questão, para Paz, significa que a teoria do

\footnotetext{
11 "Teoria e realidade em tempos de desilusões: Sobre escritos de Negri \& Hardt", disponível em http://passapalavra.info/2009/12/16688. Como informa o site, o Passa Palavra se apresenta como um coletivo que constitui "um grupo de orientação anticapitalista, independente de partidos e demais poderes políticos e econômicos, formado por colaboradores de Portugal e do Brasil, cujo intuito maior é o de construir um espaço comunicacional que contribua para a articulação e a unificação prática das lutas sociais."
} 
trabalho imaterial se distancia dos milhões que trabalham em jornadas extenuantes em meio a um mercado competitivo e excludente, logo, pouco agrega aos esforços pela mudança radical na sociedade.

Em outro artigo publicado no Passa Palavra ${ }^{12}$, Liberato também comenta as teses de Negri, mas de uma forma menos dura. O autor começa fazendo uma crítica das críticas da obra do teórico italiano, afirmando que muitas das interpretações, entre elas a realizada por Lessa, não são consistentes porque levam a crítica a um extremo que afasta a possibilidade de diálogo e beira a ridicularização; uma leitura "que precisa ser evidentemente referida a distorções das proposições daquele que se critica" (LIBERATO, 2010). Assim, Liberato propõe apontar caminhos para uma crítica pertinente da obra de Negri. O artigo escrito por Fernando Paz, detalhado acima, também é alvo das observações do autor. Liberato não compartilha o apontamento feito por Paz, confirmada por Lessa, de que a teoria do trabalho imaterial teria eliminado a distinção entre capital e trabalho ou tornado a mercadoria mero produto ideológico. Segundo Liberato, não há nos escritos de Negri nenhuma base para se fazer tal afirmação, atentando que o conceito de hegemonia do trabalho imaterial, e não de sua exclusividade, é mais importante do que o conceito de trabalho imaterial em si.

Tirando as ambiguidades ou antinomias ao longo da própria evolução
do conceito, hegemonia do trabalho imaterial para Negri e Hardt
significa que uma certa forma de trabalho tende a disseminar seus
elementos e características a outras formas de trabalho e à sociedade
em geral. E a característica principal, para eles, desse trabalho
(imaterial) que estaria se tornando hegemônico, seria o de se constituir
numa cooperação autônoma (pré-constituída) em relação à empresa
capitalista (aqui já vemos que há separação evidente entre trabalho e
capital nesse conceito), e na qual os instrumentos de trabalho em
grande parte seriam capacidades gerais das pessoas, incorporadas a
elas - o intelecto geral (LIBERATO, 2010).

No entanto, Liberato questiona se a potencialidade emancipadora do trabalho imaterial é de fato universalizável ou "está circunscrita a categorias localizadas socialmente, geograficamente e economicamente, que não apresentam prática política expressiva" (idem). $\mathrm{O}$ autor discorda da interpretação feita por alguns intelectuais, a partir das teses do trabalho imaterial, de que Negri sustenta a existência de um comunismo compatível com o Estado e o capital. Liberato entende que, para Negri, "o comunismo é algo latente, cujos pressupostos já existem na nossa sociedade" (ibidem). Como fez Marx, Negri procura o comunismo e tenta embasá-lo "nos fatos econômicos ou sociais

\footnotetext{
12،'Sobre Negri e Hardt”, disponível em http://passapalavra.info/2010/01/17173
} 
presentes, tendenciais, nas potencialidades existentes, no fazer da sociedade, e não fora dela". No pensamento de Negri, o conceito de comum, um público não-estatal, pressupõe a constituição de um comunismo que negue o Estado. "O mais estranho, no entanto, é não se dar conta de que Negri desde os anos 1970 tem se chocado contra correntes leninistas as mais diversas, sejam reformistas ou revolucionárias, sobre a questão do ataque imediato ao Estado" (LIBERATO, 2010).

Liberato enfatiza que uma crítica embasada de Negri deve levar em conta as raízes do pensamento operaísta que tentou articular uma classe trabalhadora dispersa e com múltiplos sujeitos, entre eles operários fabris, funcionários do setor terciário, desempregados e jovens proletários precarizados. Não é possível dizer que foi bemsucedida a tentativa de unificar esses diferentes sujeitos e atenuar o estranhamento entre eles. Retornando à questão da universalização da teoria do trabalho imaterial, Liberato supõe que, em última análise, "a teoria de Negri carece de um sujeito político que lhe sirva de referente", um problema que acomete teorias clássicas da crítica da economia política, como o conceito de trabalho produtivo de Marx, que pretendia pragmaticamente fundamentar e legitimar um sujeito político que apresentava um antagonismo. "O sujeito político sempre antecipa a teoria, que, se tem alguma valia, serve para reforçar a autoconfiança desse sujeito, reforçar seu fazer e dar legitimidade a seus objetivos". Porém, o alcance da potencialidade criada pela hegemonia do trabalho imaterial esbarra na baixa popularidade do novo léxico, ainda restrito aos trabalhadores imateriais de alto escalão - envolvidos com informática, comunicação e pesquisa científica. A assimilação desse novo léxico por outros grupos sociais seria, portanto, um desafio.

É relevante trazer o comentário escrito por João Bernardo que se encontra logo após o texto de Liberato na página do veículo Passa Palavra. Inscrito na corrente marxista das relações sociais de produção ${ }^{13}$, o português pontua que a substituição do fordismo pelo toyotismo causou o crescimento da exploração do componente intelectual do trabalho, tornando impertinente a separação entre indústria e serviços, uma vez que ambas as

\footnotetext{
${ }^{13}$ Segundo o marxismo heterodoxo, a exploração do trabalho funda as relações sociais capitalistas, que por sua vez moldam as forças produtivas - e não o inverso. Assim, julga-se essencial o papel da luta de classes através de uma organização coletiva e ativa capaz de deter a fragmentação dos trabalhadores. Na obra "Economia dos conflitos sociais" (2009), Bernardo critica a luta ordenada por sindicatos porque limita a ação direta, afirma a passividade das bases, anula a atuação criativa e é facilmente assimilada pelo capitalismo. Já a luta coletiva possui uma tendência prática ao controle dos processos econômicos porque os trabalhadores tomam e recriam os meios de produção.
} 
atividades são produtoras de mais-valia e obedecem ao mesmo sistema de organização do trabalho. "Uma vez mais, o que importa são as relações sociais estabelecidas no processo de trabalho e não o facto de o resultado desse trabalho obedecer ou não à lei da gravidade" (BERNARDO, 2010).

Contudo, neste quadro de crescente apropriação do trabalho intelectual pelo capitalismo, existem dois tipos de empregados: os que não podem controlar sua produção intelectual nem organizar seu tempo de trabalho independentemente das pressões do capital, e aqueles que pertencem às hierarquias de controle e organização da produção alheia. "Uns são trabalhadores produtivos, explorados; os outros são gestores capitalistas, exploradores" (idem). A classe dos gestores, que segundo Bernardo se apodera do capital no plano organizativo, joga ao lado da burguesia, a classe tradicionalmente detentora do capital no plano jurídico. Para o autor, a terceirização e a subcontratação não interferem no antagonismo entre trabalhadores e gestores. Ele explica que a concentração econômica e a precarização do emprego acabaram dispersando a concentração jurídica do capital, o que possibilitou a uma pequena sede - em que se concentra o capital - o uso de técnicas de controle eletrônico para organizar um grande número de subcontratantes e trabalhadores individuais.

Logo, o que importa é a clivagem no interior das relações de trabalho, e não a observância dos limites jurídicos da empresa que só dizem respeito às relações de produção. Bernardo julga que os teóricos do trabalho imaterial não efetuam uma análise dos mecanismos de exploração no novo quadro de exercício do trabalho. E os gestores do capital são os que mais se beneficiam da ausência de clivagem nas teses que "reformulam na época contemporânea uma ambiguidade social que tem viciado a esquerda anticapitalista e a tem conduzido às suas derrotas históricas” (idem).

Ao constatar a diversificação e a fragmentação do trabalho, Antunes (1999) passa a denominar a classe trabalhadora de "classe-que-vive-do-trabalho". Conforme essa nova concepção, compõem a totalidade do trabalho coletivo assalariado trabalhadores produtivos, diretos e indiretos, e os trabalhadora improdutivos. Estes estão empregados nos serviços público e privado enquanto produtores apenas de valor de uso, o que não invalida sua participação ativa no processo de valorização do capital, seguindo as mesmas premissas e fundamentos materiais que ordenam o trabalho produtivo. A crescente imbricação entre trabalhadores produtivos e improdutivos, essencial para a 
manutenção do sistema produtivo atual, caracteriza essa ampliada noção de classe que trabalha, na qual se incluem desempregados, proletariado rural, proletariado industrial, assalariados em serviços, precarizados e informais (sem carteira assinada). E excluemse os gestores do capital e aqueles que vivem de especulação e juros, além de pequenos empresários, pequena burguesia urbana e rural proprietária.

Antunes assinala que essas transformações no mundo do trabalho ocorrem em um contexto de transnacionalização do capital umbilicalmente ligado ao advento da teleinformática ou telemática. A convergência entre os novos sistemas de telecomunicação por satélite e a cabo, as tecnologias de informação e a microeletrônica possibilitou às empresas e aos bancos o maior controle e expansão dos seus ativos e operações em escala mundial. Assim, o trabalho social contemporâneo adquire complexidade e intensidade. O conhecimento científico é elemento constituinte da nova configuração do trabalho, porém, ao ver de Antunes, não deve ser considerada uma força produtiva independente.

Antunes observa que a vida cotidiana, fora do trabalho, tem grande potencial para gerar a subjetividade autêntica, aquela que não é vendida para o capital e por ele produzida. A vida cotidiana, ele diz, é espaço de luta entre a alienação e a desalienação, uma zona de mediação entre o mundo da materialidade e a vida humana que pode ser o ponto de partida do processo de humanização do ser social. Essa potencialidade, entretanto, não descarta o trabalho como a pré-condição da reprodução social, por isso o reino da necessidade tem forte influência sobre o reino da liberdade. Logo, Antunes aponta a redução da jornada de trabalho como a condição preliminar para se obter a emancipação. O autor vislumbra outro sistema de metabolismo societal, formado pela associação livre de trabalhadores, na qual eles gozariam de plena autonomia e tempo livre. A produção, segundo o autor, se voltaria principalmente aos valores de uso e não aos valores de troca. Assim, se eliminaria a produção destrutiva e a lógica do mercado perderia o sentido.

Enunciar a existência de duas formas de trabalho, material e imaterial, não deve supor que as duas são uma só. Ambas possuem suas identidades e se vinculam na dinâmica de produção de mais-valia. É unânime a constatação de uma nova configuração do regime capitalista e da classe trabalhadora. Decorrente da reestruturação do modelo de produção, a ordem neoliberal legitimou o poder dominante do capital sobre o Estado e 
as instituições representativas, como partidos políticos e sindicatos. O exercício da democracia parece distanciar-se ainda mais da base da sociedade, dispersa diante do príncipe eletrônico, como disse Ianni (2000) anteriormente, ou do Império, como nomeou Negri (2003).

A progressiva exploração do trabalho imaterial, seja ele hegemônico ou não, gera novas possibilidades de opressão e resistência, dois opostos em contínua interpenetração. As lutas tensionam a organização do capital e são tensionadas por ela. Porém, pertencer a um grupo seleto de trabalhadores imateriais especializados não significa ter, imediatamente, uma inclinação maior a um projeto revolucionário, mesmo que a instauração de um Estado socialista à soviética não esteja entre as estratégias de luta. Por outro lado, a análise da articulação de coletivos autônomos anticapitalistas deve observar que os militantes envolvidos estão, em diferentes níveis, imersos em um mundo de alta produção e consumo imaterial. O capítulo que segue vai trazer algumas experiências vivenciadas desde o início deste século que se posicionam como contrahegemônicas e manifestam a busca pela autonomia, peça-chave para entender os movimentos políticos engendrados na atual fase do capitalismo.

\section{3-Experiências autônomas recentes: autonomia política e comunicativa}

\section{1- Zapatismo ${ }^{14}$, a vanguarda}

A luta zapatista nos anos 1990 foi uma das inspirações do ciberativismo, termo que designa grupos que usam a internet como suporte para organização e difusão de mobilizações (DI FELICE, 2008). Figueiredo $(2006)^{15}$ situa o movimento mexicano no contexto da crise das esquerdas, em um cenário de "otimismo yuppie" com o modelo econômico neoliberal. Figueiredo observa que a realidade política mexicana, na época, era marcada pela falta de recursos econômicos e pelo amadurecimento das massas, cujo imaginário alimentado pela Revolução Mexicana de 1910 fortalecia o desejo por democracia.

\footnotetext{
${ }^{14}$ O nome faz referência a Emiliano Zapata, herói derrotado da revolução mexicana de 1910. Sob o lema "Terra e Liberdade", lutou ao lado do anarquista Flores Magón.

15 A obra resulta de uma pesquisa de campo realizada no México de 1998 a 1999. O estudo, que baseará boa parte deste tópico, buscou fazer uma reconstituição histórica cruzando documentos, reportagens e entrevistas com militantes zapatistas.
} 


\begin{abstract}
"O cenário político encontrado na cidade do México era o de um regime autoritário em crise, porém, ainda muito forte e ameaçador, que cedia através de reformas lentas à luta pela democracia. Mas o alcance dessas transformações era ainda muito limitado. Temia-se um retrocesso repentino ou a dilaceração que poderia provocar uma guerra civil. Temia-se também o próprio Estado e seus órgãos de segurança, que mantinham os militantes sob constante vigilância". (FIGUEIREDO, 2006, p. 6)
\end{abstract}

Segundo o autor, o Partido Revolucionário Institucional (PRI), hegemônico durante décadas, tentou aplacar a revolta popular penetrando nas comunidades indígenas, fracionando-as e intensificando o conflito entre elas. Figueiredo narra o crescente processo de corporativização ao qual a sociedade mexicana começou a assistir na década de 1930. Embora a constituição de 1917 - inspirada na doutrina anarcossindicalista do revolucionário Flores Magón - tenha estabelecido a desmercantilização do trabalho e lançado as bases para o moderno Estado Social de Direito, os empresários ganhavam mais poder e autonomia do que os outros setores da sociedade $^{16}$. Exaltando a paz social, o progresso material e o nacionalismo, o governo mexicano abria canais para a representação de interesses econômicos e a promoção de objetivos pessoais, mas não permitia o questionamento da ordem política.

Figueiredo analisa que, apesar de relativa e insuficiente, a reforma agrária foi vital pra incorporar camponeses, alavancando o crescimento da produção agrícola junto com o consumo interno de produtos manufaturados. No entanto, com a demanda dos Estados Unidos por produtos agrícolas, a reforma agrária foi retardada. Enquanto os salários eram mantidos a um nível baixo, aumentava a entrada de capital externo e o investimento em infra-estrutura no norte do país. Nos anos 1960, ainda segundo Figueiredo, a hegemonia do Estado começa a entrar em crise, provocada por fatores como o acirramento da competitividade eleitoral, a autonomização política da sociedade, a urbanização e o crescimento da classe média. As políticas neoliberais adotadas nos anos 80 aumentaram a ameaça ao controle político e eleitoral antes assegurado por medidas clientelistas.

No estado de Chiapas $^{17}$, onde foi organizado o levante zapatista, os efeitos do neoliberalismo foram nocivos para as populações indígenas. $\mathrm{O}$ aumento do número de propriedades privadas garantia a autonomia das elites, que mantinham um sistema

\footnotetext{
${ }^{16}$ O Partido da Ação Nacional (PAN), fundado em 1939, teve importante papel na defesa dos interesses do setor empresarial, representado a direita mexicana.

${ }^{17}$ Chiapas foi incorporado ao território mexicano em 1824. A adesão justificou-se pela famosa expressão "Mais vale ser calda de leão do que cabeça de rato".
} 
colonial racista. O projeto de modernização só beneficiava as hierarquias tradicionais, espalhando a corrupção e esgotando os recursos naturais. Enquanto isso, o movimento indígena independente ganhava força na luta contra as oligarquias, o Estado e a elite de caciques indígenas formada durante a penetração do PRI nas comunidades (idem, p.67). Figueiredo ressalta a importância da Igreja no fortalecimento da ação indígena autônoma $^{18}$. A catequese de integração pretendia envolver as bases com um discurso que buscava extrair o amor cristão das tradições indígenas e incrustar a ideia da busca pela terra prometida.

A importância da Igreja deve ser considerada, porém a origem do zapatismo está na Força de Libertação Nacional (FLN), agrupamento militar marxista-leninista de inspiração cubana, formado em 1969 por militantes da classe média urbana. O grupo guerrilheiro tentou ocupar a Selva Lacandona, no pobre sul do país, usando uma plantação de pimenta como disfarce. No entanto, a descoberta do grupo guerrilheiro pelo Exército levou a incursão ao fracasso. Em 1983, integrantes da FLN, entre os quais o célebre sub-comandante Marcos, adentraram a floresta pela segunda vez, com o objetivo de formar um exército popular. A estratégia adotada consistia na acumulação de forças em silêncio que desembocaria em uma guerra popular prolongada. Para tanto, foi necessária a aproximação paulatina com as comunidades indígenas, que deu certo devido à absorvência das práticas políticas das comunidades indígenas e ao afrouxamento da hierarquia. Para Harvey $(2010)^{19}$, essa fusão de elementos indígenas e ocidentais criou uma forma híbrida de movimento. "Um movimento horizontal, mas com formas militares hierarquizadas", caracteriza o geógrafo.

Após anos de preparação para o levante armado, em 1993 a declaração de princípios foi aprovada, constituindo, de fato, o Exército Zapatista de Libertação Nacional (EZLN). No primeiro dia do ano de 1994, logo depois da celebração - pelas elites políticas e econômicas, únicas beneficiadas pelo acordo - da entrada do México no Tratado NorteAmericano de Livre Comércio (Nafta), três mil combatentes zapatistas, mestiços e indígenas ocuparam sete cidades de Chiapas, entre elas a importante San Cristoban de

\footnotetext{
${ }^{18}$ Desde 1940, o Instituto Nacional Indigenista defende os camponeses a fim de reforçar os benefícios da Reforma Agrária.

${ }^{19}$ Harvey comentou o caráter híbrido do zapatismo em entrevista concedida à revista Carta Capital. Disponível em http://www.cartacapital.com.br/sociedade/201czapatismo-foi-um-movimento-indigenacom-caracteristicas-ocidentais201d-7784.html.
} 
las Casas, habitada por forte elite racista e repressora. A primeira declaração da Selva Lacandona, divulgada para além das fronteiras mexicanas, evocou o direito constitucional segundo o qual "todo poder público emana do povo e se institui em benefício dele" 20 . Assim, o EZLN declara guerra ao exército federal mexicano, braço armado do governo chamado pelos zapatistas de ditadura. Ao reivindicar direitos básicos como trabalho, terra, educação, independência, liberdade, democracia, justiça e paz, o exército zapatista chamou o resto da sociedade para se integrar às forças insurgentes. Entretanto, Figueiredo aponta que a repressão e a dificuldade financeira fizeram o movimento focar no aspecto político e comunicativo, iniciando uma guerra de papel. O enfoque na comunicação já pode ser percebido no primeiro dia do levante, quando os militantes ocuparam rádios e depredaram signos de autoridade. Nos primeiros dias de levante, a ampla cobertura da mídia corporativa - que tratou o movimento como mercadoria - e a abundância de informações já anunciavam as batalhas midiáticas que estavam por vir.

A estratégia centrada na participação política e na comunicação atrela as conquistas do movimento à capacidade de diálogo com a sociedade civil. $\mathrm{O}$ objetivo de formar ampla aliança nacional que pressionasse o governo dependia, em grande parte, da projeção do EZLN na mídia e na vida pública nacional e mundial. A visibilidade dos zapatistas aumentou a pressão popular que pedia diálogo e o fim da violência estatal. Com o reconhecimento, o movimento expandia a diversidade de perfis dos ativistas, o que sustentava o lema "Por um mundo onde caibam muitos mundos". A valorização das diferenças, sempre vinculada ao debate sobre autonomia, fomentou o feminismo dentro do zapatismo. Harvey (2010) exalta a importância da questão de gênero para os zapatistas: "os direitos das mulheres estavam arraigados muito neste movimento, o que não é necessariamente verdade em outras populações indígenas e na esquerda" (HARVEY, 2010).

Os zapatistas eram independentes das burocracias partidárias, dos grandes movimentos sociais e das ONGs. Os indivíduos que, como os indígenas, não estavam familiarizados com a política tradicional, também tinham voz no movimento plural, e não eram meros objetos de planos estratégicos (FIGUEIREDO, 2006). Conferia-se àqueles que não tiveram formação intelectual nos moldes ocidentais o direito de ter espaços e

20 Trecho da Carta Magna mexicana citado na primeira declaração zapatista, disponível em https://www.nodo50.org/insurgentes/textos/zapatismo/lacandona1.htm. 
visibilidades próprias. O sujeito político era entendido como um participante direto das transformações na civilização, e não dependente da mediação de intelectuais e políticos do ocidente. Figueiredo observa que a autonomia zapatista também era vista nas formas de deliberação, baseadas no consenso, diferenciando o movimento de outras organizações hierarquizadas. "Esta é uma prática tradicional indígena que foi reinventada nos discursos do zapatismo civil, foi aplicada, por exemplo, na organização do FZLN e teve difusão internacional particularmente forte entre grupos anarquistas”, explica o autor.

Downing (2004) aponta que, na perspectiva zapatista, o diálogo era um veículo para a ação política. $\mathrm{O}$ autor vê na criação de uma arena de inclusão dos marginalizados pelo discurso hegemônico uma forma de legitimar uma contraesfera pública subalterna, para citar o conceito da teórica feminista Nancy Fraser ${ }^{21}$. Consultas, convenções e assembleias estreitavam o vínculo com a sociedade civil e legitimavam o movimento perante o governo. Essa esfera pública radical se manifestava em espaços como as Aguascalientes, centros de reunião nos quais a sociedade civil discutia políticas públicas em reação às medidas neoliberais. $\mathrm{O}$ apoio da sociedade civil $^{22}$ se traduziu não só na participação em eventos, mas na observação de direitos humanos e na ajuda humanitária. A participação da sociedade afastava ainda mais o movimento do embate armado, aumentando a ênfase na dimensão política e comunicativa ${ }^{23}$.

Figueiredo assinala a atração que exerceram o discurso, as práticas democráticas e as imagens lúdicas do zapatismo, "a ponto de oferecerem um novo referencial ideológico e até uma nova linguagem para os ativistas de esquerda" (FIGUEIREDO, 2006, p. 256). A dimensão espetacular e performática expressava-se na apresentação dos zapatistas, que usavam lenços e gorros para manter o anonimato e evitar personalismos, e nos discursos - a maioria deles assinados pelo sub-comandante Marcos. Os comunicados zapatistas, descreve o autor, carregavam valores morais, senso de humor e recursos de estilo literário, que "os distinguiam dos textos políticos típicos, sérios e pretensamente racionais a que o público estava acostumado" (idem, p.135). Os discursos restauraram o

\footnotetext{
${ }^{21}$ FRASER, Nancy. Rethinking the public sphere: a contribution to the critique of actually existing democracy. In: CALHOUN, Craig (Ed). Habermas and the public sphere. Cambridge: MIT Press, 1996.

${ }^{22} \mathrm{O}$ contato com artistas, políticos e intelectuais ampliava a representatividade do movimento.

${ }^{23}$ Em 1996, a quarta declaração da Selva Lacandona já enfatizava vastas redes de comunicação e solidariedade e colocava a opção pela via política. A substituição de EZLN por FZLN (Forças Zapatistas de Libertação Nacional) expressa bem essa mudança.
} 
romantismo revolucionário e o radicalismo mesclando a recusa à política institucional e valores hegemônicos na esquerda, como a luta pela via pacífica e por valores democráticos.

A presença nos círculos do discurso dominante produzido pela mídia corporativa não tornava os zapatistas dependentes dos meios de comunicação tradicionais. Enquanto tentavam criar uma boa relação com os principais veículos de informação, os zapatistas “inspiraram o desenvolvimento de uma rede próspera, extensa e diversificada de comunicação radical que lhes deu a oportunidade de comunicar-se diretamente com a sociedade civil" (DOWNING, 2004, p. 294). Por isso, o uso da Internet foi fundamental para a construção dessa rede de comunicação e solidariedade internacional. O emprego de recursos de comunicação alternativos contornou o risco de censura oficial e alimentou a difusão e o debate dos acontecimentos. A utilização radical de tecnologias de comunicação, de acordo com Downing, servia às estruturas de tomadas de decisão coletiva e democrática. As comunicações via Internet eram traduzidas para vários idiomas e divulgadas a comunidades distantes, fortalecendo as ações coordenadas de solidariedade que envolviam ativistas do mundo todo. Entre as práticas comunicativas virtuais, Downing cita as listas de discussão, o grupo de discussão e o site, que funcionavam como fóruns públicos e fontes de informações.

Porém, Figueiredo relaciona um dos problemas enfrentados pelo zapatismo à falha na comunicação com indígenas de Chiapas não habituados aos meios de comunicação eletrônicos. Outro obstáculo apontado pelo autor foi a diminuição da capacidade de articulação com a sociedade civil no fim dos anos 1990, provocada pela ausência de um programa político. Houve períodos de silêncio em que a frequência dos comunicados foi reduzida e os diálogos com o governo interrompidos. Do lado do governo a estratégia consistia em uma guerra de baixa intensidade, na qual o exército e grupos paramilitares financiados pelos grandes proprietários de terra cercavam as comunidades e inibiam consultas e assembleias. Uma ofensiva paramilitar que matou 45 pessoas motivou, em janeiro de 1997, uma ação global que uniu ativistas de 130 cidades de 27 países nos cinco continentes. 
A despeito do enfoque comunicacional comumente dado à luta zapatista, algumas análises optam por enfatizar o aspecto material do movimento. Liberato $(2009)^{24}$ pontua que a imagem do zapatismo centrada na guerra simbólica pode omitir a base fundamental da luta: a tomada dos meios de produção. Tal afirmação baseia-se na fala do Subcomandante que declara que "as teorias não apenas não devem se isolar da realidade, mas também devem buscar nela as marretas que às vezes são necessárias quando se encontra um beco sem saída conceitual" (MARCOS apud LIBERATO, 2009) ${ }^{25}$. Embora reconheça a importância incomensurável do uso dos meios de comunicação, especialmente a Internet, pelos zapatistas, Liberato destaca na fala do subcomandante a referência à base material das mudanças, mesmo que limitadas, pelas quais passaram as comunidades indígenas após o levante de 1 de janeiro de 1994. Segundo Liberato, a tomada dos meios de produção foi

\begin{abstract}
a base e condição necessária para que pudessem declarar seus Municípios Autônomos e experimentarem sua autonomia, no sentido profundo de autogoverno (de se dar as próprias leis), através de novas formas políticas como são hoje as Juntas do Bom Governo. Sem a tomada dos meios de vida, ou dos "meios de produção", na expressão usada por Marcos, não alcançariam a mudança na vida, desenvolveriam suas instituições educacionais e de saúde, experimentariam o poder político e o autogoverno que possuem hoje (LIBERATO, 2009).
\end{abstract}

Segundo as palavras de Marcos extraídas por Liberato, os processos observados nos territórios zapatistas só puderam se desenvolver quando a terra passou para as mãos dos camponeses. A tomada dos meios de produção, no caso a terra, os animais e as máquinas, foi o ponto de partida para os avanços em governo, saúde, moradia, alimentação, participação das mulheres, comercialização, cultura, comunicação e informação. O subcomandante vê a propriedade dos meios de produção e troca como o núcleo central do sistema capitalista, que precisa ser destruído por um movimento antissistêmico que integre diferentes indivíduos excluídos pelo capitalismo. Liberato conclui o artigo questionando como a experiência zapatista pode inspirar perspectivas anticapitalistas nos centro urbanos, onde a especulação imobiliária é parte fundamental do processo de valorização do capital.

\footnotetext{
24 Em artigo intitulado "O neozapatismo e os velhos meios de produção", disponível em http://passapalavra.info/2009/04/2280.

25 A fala do comandante militar do exército zapatista foi proferida durante o colóquio realizado em dezembro de 2007 em San Cristobal de las Casas, México. Os áudios do colóquio podem ser baixados aqui: http://radioinsurgente.org/index.php?name=pagetool_news\&news_id=252.
} 
As grandes capitais revelam com intensidade a precarização do mundo do trabalho e as novas formas de produção e exploração. O desafio posto pela luta dos zapatistas cobra dos militantes uma atuação que invista tanto em bases materiais geradoras de novas relações sociais como novas narrativas e representações sociais. O movimento zapatista serviu não só para consolidar Chiapas como uma Meca da esquerda internacional (FIGUEIREDO, 2006), mas para impulsionar as redes internacionais de ativistas que formaram os movimentos anticapitalistas na virada para o século XXI. O próximo tópico se dedicará à compreensão dessa rede contra-hegemônica que aprendeu com os zapatistas a utilizar os meios de comunicação digitais para produzir, organizar e difundir horizontalmente a informação.

\section{2- A emergência de uma rede tão global quanto o capital}

\subsection{1- A Ação Global dos Povos}

A turbulência provocada pelos zapatistas não fez com que as circunstâncias econômicas que inflaram o levante desaparecessem. Ao longo dos anos 1990, o processo de liberalização econômica se intensificou com o aumento da mobilidade global de capitais - concentrados nas mãos de poucas e poderosas companhias transnacionais organizadas em blocos -, criando novas formas de acumulação e exploração. Enquanto isso, a capacidade de proteção social do Estado esvaziava-se, tornando o capitalismo ainda mais excludente. Em resposta a esse contexto, em 1997 os zapatistas promoveram em Madrid, na Espanha, o Encontro Interplanetário pela Humanidade e contra o Neoliberalismo, ocasião em que foi fundada uma rede global contra o livre comércio: a Ação Global dos Povos. Com o intuito de unir pessoas em torno de princípios comuns, um grupo formado por dez movimentos sociais, entre eles o Movimento Sem Terra $(\mathrm{MST})^{26}$ brasileiro e o Sindicato dos Agricultores do Estado de Karnataka (KRRS), da Índia, lançou quatro pontos de partida: a rejeição às instituições neoliberais, uma atitude de confronto, uma organização baseada na descentralização e autonomia e uma

\footnotetext{
${ }^{26}$ Com a formação da Via Campesina, rede internacional de movimentos camponeses, o MST deixou de protagonizar a AGP, embora nunca tenha se afastado totalmente.
} 
chamada para a desobediência civil não violenta e a construção de alternativas locais pelas comunidades locais (LUDD, 2002) ${ }^{27}$.

Os Dias de Ação Global ${ }^{28}$ estavam por vir como um movimento de resistência que, assim como o capital, não enxergava fronteiras. O objetivo era coordenar ações que ocorreriam simultaneamente em vários pontos do globo a fim de atingir o coração da economia global, expresso nos centros financeiros, distritos bancários, sedes decorporações multinacionais e, principalmente, organismos gestores do capitalismo como a Organização Mundial do Comércio (OMC), o Banco Mundial (BM) e o Fundo Monetário Internacional (FMI). Durante a primeira conferência da AGP, em fevereiro de 1998 - em Genebra, lar da OMC -, mais de 300 delegados de 71 países trocaram experiências e concordaram em criar "uminstrumento global para comunicação e coordenação de todos aqueles que lutam contraa destruição da humanidade e do planeta pelo mercado global, enquanto constroemalternativas locais e poderes populares" (LUDD, 2002, p.15). Entre os dias 16 e 20 de maio de 1998, atos de resistência espalhados pelo mundo deram a primeira mostra da aliança que se formava. $O$ saldo desses quatro dias foi a necessidade de construção de uma ação maior, focada na realização de protestos e ações autônomas nos distritos financeiros de todo o mundo. Mobilizou-se, então, oJ18, 18 de junho de 1999, que coincidiu com o encontro do G8, cúpula dos países mais ricos do planeta, na cidade alemã de Colônia.

Mas o N30 - 30 de novembro do mesmo ano - foi o evento que efetivamente popularizou a AGP, fortalecendo a rede internacional que propunha criar conexões e oferecer alternativas à ordem social vigente. $\mathrm{O}$ primeiro dia de reunião ministerial da OMC em Seattle, nos Estados Unidos, foi impedido pela organização simultânea de protestos envolvendo ONGs, sindicatos e movimentos de ação direta ${ }^{29}$. Segundo Ortellado $(2002)^{30}$, a simultaneidade das iniciativas dessas três esferas, que mantinham pontos de contato entre si, atingiu "um clima político que possibilitou que as demandas de alguns países do terceiro mundo que eram contra as medidas ultraliberais da OMC

\footnotetext{
${ }^{27} \mathrm{Na}$ terceira conferência realizada pelo movimento, em 2001, os princípios foram modificados, ganhando caráter explicitamente anticapitalista. O termo "não-violento" foi abolido para evitar divergências devido às diferentes concepções de "não-violência".

${ }^{28}$ Os dias de ação Global ocorreram entre 1999 e 2001.

${ }^{29}$ Nos Estados Unidos, grupos de jovens de ações direta haviam formado DAN (Rede de Ação Direta), cujos dissidentes adoraram a tática Black Block (bloco negro), voltada para a destruição de propriedade de grandes empresas. A ideia de diversidade de táticas permitiu a convivência dessas duas vertentes.
} ${ }^{30}$ Artigo "Aproximações ao "movimento antiglobalização”,
http://www.midiaindependente.org/pt/blue/2002/01/14525.shtml disponível 
fossem ouvidas", levando ao fracasso a rodada do milênio que prometia impulsionar a liberalização comercial.A ampla cobertura midiática da "batalha de Seattle" batizouos protestos de movimento antiglobalização, o que não agradou os ativistas ligados à AGP. Em entrevista concedida para esta pesquisa, Elisa, militante da coalizão inspirada pela AGP em São Paulo, contesta:

\begin{abstract}
"A luta é tão global quanto o capital. Não é antiglobalização, é anticapitalista. É contra a globalização das corporações, não contra a globalização da luta. As ações da AGP, coordenadas no mundo inteiro ao mesmo tempo, foram globais. Falar antiglobalização parece que você é contra os avanços da globalização. Não é isso, a gente é contra o capitalismo" (Elisa, entrevista, São Paulo, fevereiro de 2014).
\end{abstract}

No entanto, a Ação Global dos Povos acabou ficando conhecida como movimento antiglobalização, nome que é, em si, "um efeito midiático e espetacular, embora os movimentos sociais, coalizões, grupos, coletivos e redes que produziram o espetáculo tenham vida para além dos efeitos que causam” (LIBERATO, 2006, p. 123).Diferente do que os noticiários de TV mostraram na época, os movimentos de ação direta que formaram a AGP, segundo Ortellado (2002), têm uma história múltipla e plural, poiso movimento de cada país tem sua história específica. $\mathrm{O}$ autor ressalta que os movimentos de ação direta dos jovens americanos, ingleses, alemães e italianos forjaram as principais variantes do ativismo de ação direta no mundo. "Em comum, apenas a participação de um grande número de estudantes e uma cultura ativista de origem hippie ou punk consolidada nos anos 70 e 80" (ORTELLADO, 2002).

Nos Estados Unidos, a origem está no movimento ecológico e antinuclear. Lá, o movimento adquiriu os contornos vistos em Seattle:ênfase na decisão por consenso, organização por grupos de afinidade - prática recuperada da organização anarquista - e a prática da desobediência civil não violenta. Enquanto que na Itália e Alemanha o movimento remonta à Autonomia, conjunto de correntes e práticas desenvolvidas nos anos 70 e 80 a partir do movimento estudantil radical e apartidário, do movimento feminista, do movimento de ocupações urbanas de jovens e do movimento operário de base e de ação direta. O Bloco negro ou Black Block, grupo de manifestantes radicais que garantem proteção durante as manifestações, é uma das práticas desenvolvidas no seio da autonomia. As correntes políticas autônomas beberam na fonte da contracultura, que nos anos 1960 uniu-se ao radicalismo político. A dimensão criativa das manifestações da AGP herdou da contracultura a fusão da reivindicação com a autoexpressão. Ortellado observa a preocupação dos ativistas - notada nos treinamentos 
de ação direta e desobediência civil - em subordinar o princípio da autoexpressão aos objetivos políticos, caso contrário o protesto perderia a funcionalidade. Táticas comuns nos dias de ação global como bloqueios, ocupações, tortadas em autoridades e teatros de rua deveriam aliar-sea estratégias políticas.

A AGP não deve ser interpretada como um movimento unificado e homogêneo, pois, na verdade, trata-se de um instrumento de coordenação. Para esclarecer as peculiaridades da AGP, Ortellado (2004) diferencia redes de organizações tradicionais. De acordo com o autor, organizações tradicionais manifestam um agente uno e coerente, possuem estrutura determinada e aparência de unidade, embora divergências sejam frequentes.

\begin{abstract}
Ainda assim, a lógica da organização (seja ela democrática ou hierárquica) é unificar as posições para poder apresentá-las com a força da totalidade dos membros. Uma organização que tenha milhares de filiados não apresenta suas posições como as posições do grupo dominante, mas como a posição da organização como um todo. É a força dessa unidade que lhe dá o poder político de negociação, pressão ou barganha com o qual se relaciona com outras organizações (ORTELLADO, 2004, p. 4).
\end{abstract}

Já as redes são flexíveis, fluidas, plurais e descentralizadas ${ }^{31}$. Nessa forma relativamente nova de associação, as partes - que podem ser indivíduos, organizações ou mesmo outras redes - se unem para perseguir objetivos com base em objetivos determinados e princípios gerais acordadosque restringem numa medida razoável a participação para que se mantenha uma mínima orientação política (idem).Assim, as redes preservam a autonomia de seus elementos, permitindo a convivência de grupos e indivíduos diferentes, que não precisam sacrificar suas posições particulares para atuarem em conjunto.Conforme Ortellado, as práticas diretas e horizontais manifestas em reuniões amplas, abertas e participativas constroem uma unidade verdadeira e não imposta, já que há pouco espaço para verdades hegemônicas. A fluidez e a flexibilidade também são características marcantes da rede:

Se num determinado momento, um grupo tem um desentendimento pontual, ele não precisa abandonar a rede, mas pode simplesmente não colaborar naquele ponto, da mesma forma que, em momentos específicos, a rede pode incorporar a colaboração extraordinária de novos agentes que se interessam apenas por uma ação específica. Isso significa apenas levar o velho princípio anarquista da livre-associação até a sua consequência lógica: a livre dissociação (ORTELLADO, 2004, p. 5).

\footnotetext{
${ }^{31}$ Tal definição servirá para compreender a rede autônoma que se formou em São Paulo após os protestos de junho de 2013.
} 
As ideias gerais de descentralização, democracia direta, decisão por consenso e uma desconfiança generalizada na autoridade aproximam a AGP do movimento anarquista. A ação direta, na qual as táticas dos dias de Ação Global se baseiam, é cara aos anarquistas porquefortalece a oposição à política parlamentar. O apelo à democracia direta e ao exercício da autonomia - a partir de uma política pré-figurativa, segundo a qual a forma da organização e das ações imita o modelo de sociedade desejado explicita a clara recusa aos moldes de representação da democracia burguesa, crítica que também influenciou o lema "faça você mesmo", enraizado na contracultura.

No entanto, para Ortellado, a ausência de uma hegemonia ideológica explícita sugere um anarquismo difuso.O fato de muitos ativistas se dizerem zapatistas reforça a ausência de uma orientação ideológica fechada, formandoum "horizonte amplo e genérico de consenso no movimento de que a nova sociedade que se quer deve ser uma sociedade horizontal, com práticas democráticas diretas e participativas" (ORTELLADO, 2002). Compartilhando do entendimento de Negri, Liberato afirma que a rebeldia é uma potência política cuja direção - as formas de relações sociais e as instituições a serem constituídas por essa potência - ainda está para ser descoberta e criada.Segundo sua interpretação sobre a experiência da AGP, a ação dos insubordinados não se inscreve nas relações de produção propriamente ditas, o que dificulta a identificação fixa dos ativistas com a classe trabalhadora. Ele supõe o reconhecimento desses ativistas como um grupo social localizado em um dos polos numa relação de antagonismo, uma oposição que se constrói na organização coletiva da luta.

\footnotetext{
Em outras palavras, o campo de constituição da classe é cada vez mais, em muitos casos e penso principalmente no caso dos centros urbanos, o campo da própria organização e preparação de lutas (anticapitalistas), o campo da ação coletiva; cada vez mais a luta se torna fator, e aparentemente anterior, à constituição da classe. (LIBERATO, 2006, p.28).
}

Existe um termo que serve como uma guia supraideológico para as ações da AGP: o anticapitalismo. Ortellado observa que a expressão "anticapitalista" começou a ser usada em 1999 nas discussões sobre os dias de Ação Global. Naquele momento, otermo designava a convergência de lutas específicas na luta comum contra a sociedade capitalista. A oposição, pautada pela autonomia, uniaas lutas contra a hierarquia, a homofobia, o sexismo, o racismo, o militarismo e a destruição ambiental.Pregava-sea igualdade,o respeito às diferenças e a liberdade entendida como direito à participação 
nas decisões (ORTELLADO, 2004, p.3). Mais tarde, o termo serviu para diferenciar de uma maneira anacrônica, na opinião de Ortellado- anticapitalistas de reformistas. Segundo o autor, essa distinção era apenas retórica, pois omitia o fato de que nenhum dos grupos possuía um programa consistente de transformação social.

No Brasil, especialmente em São Paulo, a adesão aos dias de ação global se deu a partir de uma coalizão de grupos anarquistas, punks e de estudantes independentes predominantemente urbanos. Uma explicação para a convergência contrária à globalização econômica vem da consolidação do ativismo autogestionário nos anos 1990, que estreitou as relaçõesdo movimento punk, em processo de politização, com o anarquismo. Ortellado (2002) explica que o anarquismo renasceu nos anos 1980 devido tanto à consolidação do movimento punk quanto à abertura democrática após duas décadas de ditadura e ao legado dos movimentos contraculturais de 60 e 70.

Liberato (2006) observa que em São Paulo, o Centro de Cultura Social (CCS), organização anarquista fundada em 1933 e reaberta em 1985, aproximou-se dos punks que passavam a afirmar uma doutrina anarquista com crescente grau de coerênciae densidade política. As atividadesdos chamados anarcopunks centravam-se em panfletagens e manifestações de rua, sob temas como militarismo, sexismo, racismo, exploração animal, educação autoritária, etc. A consolidação política do movimento punk contribuiu para o reestabelecimento doanarquismo social no Brasil, que visava influenciar com uma orientação estratégica lutas populares e classistas. Esse redirecionamento refletia a tensão entre o anarquismo focado no estilo de vida, um tanto quanto individualista, e o anarquismo mais preocupado com a luta de classes.

A coalizão de grupos e indivíduos pela Ação Global dos Povos formou-se em São Paulo no ano de 2000. Durante o S26 $6^{32}$, dia 26 de setembro de 2000, mil pessoas protestaram em frente à Bolsa de Valores na capital paulista. Além de arremessar tintas e pedras na sede da instituição, os manifestantes, dos quais 39 foram presos, promoveram teatro de rua e ocuparam o centro da cidade. A organização dessa mobilização restringiu a participação de partidos, reforçando a busca pela autonomia. Como assinala Ortellado (2002), o afastamento de partidos políticos muitas vezes se colocava como um dilema aos manifestantes, que se viam entre dois caminhos: o sectarismo e a integração com a esquerda institucional. Para tentar resolver esse impasse, durante o Fórum Social

\footnotetext{
${ }^{32}$ Contra o encontro do FMI e Banco Mundial em Praga, República Tcheca.
} 
Mundial $^{33}$ os ativistas colocaram em prática a estratégia da contaminação, que consistia em influenciar a esquerda institucional com práticas libertárias. Apesar da organização hierárquica e dos canais de participação representativa, havia oficinas que ofereciam uma participação aberta e encontros paralelos de grupos autônomos.

Ortellado comenta que a questão da liderança entre os ativistas autônomos tornou-se um tabu. A emergência de estruturas informais de poder poderia colocar em risco a construção da horizontalidade, porém a definição de estruturas claras de poder como solução do problema ${ }^{34}$ gerava discórdia. A aversão à autoridade impedia a formação de hierarquia dentro do grupo. O que ocorria, segundo Ortellado, era que os militantes mais ativos - que apresentavam disponibilidade, empenho, comprometimento e capacidade organizacional e política - tomavam com mais frequência decisões executivas. A existência de diferentes graus de ativismo ocasionava tensões entre os militantes mais engajados e os simpatizantes durante as ações nas ruas. A repressão no A20, manifestação no dia 20 de abril de 2001 contra a ALCA, decorrente da reação de participantes contrária ao que havia sido acordado em assembleia, suscitou o debate sobre o poder do mais ativo. A solução encontrada foi a decisão de tornar públicas todas as deliberações das assembleias; aquele que contrariasse seria considerado agente provocador infiltrado.

A coalizão formada em São Paulo inspirada na AGP recebeu críticas no meio libertário que observaram limitação eespontaneísmo nas ações organizadas pelo movimento (LIBERATO, 2006, p. 187). Outroponto problematizado era a identificação da AGP, em São Paulo, com a imagem de uma organização - apesar de não ter uma estrutura formal -, ao contrário do que pretendia a AGP em sua formação a nível global. Segundo Liberato, o modo como a AGP foi recebida e adotada no Brasil impôs certos limites ao seu desenvolvimento como rede ou mecanismo de coordenação de movimentos sociais. Em um artigo $^{35}$ assinado pela Federação Anarquista Gaúcha (FAG), a ação dos militantes brasileiros inspirados pela AGP carece de "constância e identidade social". O texto aponta a falta de conexão do grupo com os problemas cotidianos da população

\footnotetext{
${ }^{33}$ O FSM nasceu em 2001 a partir de uma iniciativa de grupos brasileiros e franceses a fim de organizar um grande encontro em oposição ao Fórum de Davos, reunião da elite capitalista global.

${ }^{34}$ É o que sugere Jo Freeman no artigo "A tirania das organizações sem estrutura", disponível em http://www.nodo50.org/insurgentes/textos/autonomia/21tirania.htm.

${ }^{35}$ Intitulado "Em Cada Realidade Social Específica, uma Antiglobalização Conectada com os Problemas Concretos dos Oprimidos". Disponível em http://ainfos.ca/02/may/ainfos00524.html.
} 
brasileira, gerando uma luta caricatural e imitativa. Liberato constata que o movimento antiglobalização em São Paulo foi um ponto de partida, e não um ponto de chegada resultante de um movimento ou luta primária.

$\mathrm{O}$ ataque às torres gêmeas em 11 de setembro de 2001 arrefeceu as manifestações em torno da AGP nos Estados Unidos e na Europa, o que causou um refluxo em São Paulo. Quase dois anos depois, conforme Liberato, foi realizada uma reunião em que o grupo paulista ganhou o nome de Coalizão Anticapitalista de São Paulo (CASP). Notava-se um direcionamento a uma orientação estratégia mais acentuada, a um anarquismo social e a uma adequação à realidade brasileira. Em 2003, a construção de espaços autônomos revelava um mesmo espectro político ou ideológico e o pertencimento a uma mesma geração, criando "algum vínculo entre esses grupos libertários mesmo com divergências de orientação táticas ou estratégicas" (LIBERATO, 2006, P.208). Naquele ano, esses ativistas participaram de uma ação realizada simultaneamente em cinco capitais que ocupou sedes da Agência Nacional de Telecomunicações (ANATEL) emprotesto contra o fechamento de rádios livres e comunitárias. O protesto teve a cobertura do Centro de Mídia Independente (CMI), que será abordado a seguir.

\subsection{2- O Centro de Mídia Independente}

A amplificação das imagens dos protestos em Seattle, em novembro de 1999, pelos veículos de comunicação corporativos foi importante para dar visibilidade aos dias de ação global, entretanto, depender da cobertura da grande mídia teria sido um erro. $\mathrm{O}$ contraste entre o que se via nas ruas e o que era retratado pela mídia revelava as distorções características do modelo informativo empresarial. No manifesto da $\mathrm{AGP}^{36}$, era explícito o entendimento de que "os meios de comunicação de massas e a cultura consumista das corporações são os agentes principais da mercantilização e da homogeneização da diversidade cultural". A dependência do consumo de massa, diz o texto, é resultado desse processo que exige a retomada da cultura das mãos das corporações. E complementa:

\footnotetext{
"Nós estamos profundamente comprometidos com a libertação cultural em todas as áreas da vida, da alimentação aos filmes, da música à mídia. Nós contribuiremos com nossa ação direta ao desmantelamento da cultura corporativa e a criação de espaços para a criatividade genuína” (AGP, 1998).
}

\footnotetext{
${ }^{36}$ Disponível em http://www.nodo50.org/insurgentes/textos/agp/02manifestoagp.htm.
} 
Como alternativa ao monopólio da comunicação, surgiu um dos frutos mais significativos do movimento antiglobalização: o Indymedia ou Centro de Mídia Independente (CMI). De acordo com Santos (2013), três meses antes das manifestações de Seattle, um ativista postou em um fórum da internet informações sobre um software que permitia a publicação de fotos, vídeos e relatos produzidos por ativistas, sem a necessidade de mediação de um especialista. Não demorou muito para que os ativistas passassem a utilizar o site www.indymedia.org para cobrir e testemunhar as manifestações. A ideia de uma mídia não mediada, em que o próprio manifestante é jornalista e editor, ressoava o lema "Se você odeia a mídia, torne-se a mídia", popularizada pelo cantor de punk rock Jello Biafra. Ortellado (2004), que participou da criação do CMI São Paulo, fundado em dezembro de 2000, comenta:

\footnotetext{
"Não se tratava apenas de combater a hierarquia da redação jornalística, nem o caráter industrial e capitalista da produção da notícia; tratava-se de abolir o próprio papel do jornalista enquanto mediador, criando um sistema participativo de publicação aberta. Os altos índices de acesso e a difusão dos sites do CMI mostraram que a escolha tinha sido acertada" (ORTELLADO, 2004, p. 11).
}

Após Seattle, os fins do Centro de Mídia Independente ultrapassaram a cobertura dos Dias de Ação Global. Informações sobre temas de interesse social, de movimentos sociais diversos e acontecimentos políticos tornavam-se frequentes entre as publicações do site. "Tornaria-se um veículo de mídia alternativa permanente através, principalmente, do fazer contínuo de manutenção técnica, difusão, redação etc., de coletivos que formariam parte da rede dos CMIs em cada país e globalmente" (LIBERATO, 2006, p. 182). Santos fornece os dados da rápida expansão do CMI pelo mundo: de um coletivo em 1999 para 39 coletivos em 2000 e 70 coletivos em 2001. 106 coletivos em 2002, 136 coletivos em 2003, e 162 coletivos em 2004. Em 2005, com 165 coletivos, o processo de formação de coletivos, com sites próprios, entra em fase de estabilização. A expansão da rede levou à elaboração de uma política editorial alinhada com os princípios da AGP.

Essa rede de produtores independentes de mídia tinha como objetivo oferecer informação alternativa, dando voz aos marginalizados para a construção de uma sociedade livre, justa e igualitária. A criação de laços entre indivíduos e grupos independentes que lutam através da ação direta fortalece a concepção de autonomia. A negação de filtros comerciais e estatais é uma forma de criticar o modelo social dirigido de cima para baixo. Segundo Elisa, ativista do CMI em São Paulo, a tomada de decisões 
por consenso demonstra a busca pela autonomia, citada na carta de princípios básicos assim como a horizontalidade e a transparência. O intuito, ela explica, é impedir a apropriação do site por qualquer grupo político.

\begin{abstract}
"O CMI tem uma estrutura totalmente livre de corporações e de qualquer tipo de financiamento. A gente entende que um veículo de comunicação independente não pode ser financiado por corporações nem pelo Estado. A nossa visão anticapitalista é não fortalecer essas empresas, a gente se baseia na utilização do software livre. A gente desenvolve os softwares que a gente usa, os servidores são nossos, as ferramentas são todas criadas por uma estrutura de técnicos que são da própria rede" (Elisa, fevereiro de 2014).
\end{abstract}

Elisa ressalta que a rede Indymedia foi a primeira plataforma de publicação aberta do mundo, na época da web 1.0, menos acessível - o que significa uma relação de passividade - e mais precáriado que a web 3.0 dos dias atuais.De acordo com a militante, desenvolvedores da Indymedia estão entre os criadores de ferramentas como o Twitter. "O primeiro Wiki que existiu não foi o do Wikipedia, foi o Docs do Indymedia", afirma. Ela atribui o avanço da tecnologia em uma ferramenta de participação social à ação em conjunto de pessoas interessadas em resolver os problemas técnicos que o desenvolvimento de uma rede apresenta. "Os ativistas determinaram os rumos da Internet.A Internet foi criada pelo Exército, que vive tentando controlá-la, mas os ativistas estão na vanguarda do desenvolvimento tecnológico", enfatiza.Com o barateamento da Internet, a rede de comunicação ganhou dinamismo. Liberato frisa que o baixo custo desse canal de informação baseado na publicação aberta permitiu a manutenção do CMI, mesmo em condições de baixo engajamento e precária condição financeira dos coletivos que o compõem.

Segundo Santos, a rede de comunicação integrava ativistas com distintos recursos e materiais, provenientes de distintos lugares e identificados a distintas trajetórias e concepções políticas. A conexão se dá por espaços virtuais e reais, onde as possibilidades e os limites das práticas políticas são compartilhados e pensados por indivíduos unidos em uma "mesma história de rebeldia" (SANTOS, 2013, p.108). A lógica do capitalismo informacional é subvertida na criação de redes antissistêmicas. Apropriando-se do conceito de Downing, já tratado neste trabalho, Santos trata o CMI como uma mídia radical alternativa semelhante a outras surgidas no final da década de 1990, que têm em comum as características organizacionais e políticas dos "movimentos sociaise do desenvolvimento tecnológico de sua época, espacial e historicamente situados" (SANTOS, 2013, p.109). 
Entre as experiências de mídia radical que Santos julga fundamentais para a fundação do CMI, estão o movimento do acesso livre, as TVs comunitárias, o neozapatismo e os coletivos tech. Estes, diz o autor, contribuíram para a criação da estrutura técnica e de novas práticas políticas. As atividades dos coletivos tech aproximam-se dos hacktivistas - ligados às concepções mais puristas de mídia tática - nas leituras anticapitalistas e libertárias, mas distinguem-se deles porque valorizam também a atuação fora do ciberespaço. A resistência e a rebeldia são estimuladas, em grande parte, pela participação em outros coletivos e movimentos sociais que consideram a esfera das ruas essencial para enfrentar o sistema capitalista.Exemplo de coletivo tech é oRiseup, grupo autônomo, cuja sede fica em Seattle, que fornece ferramentas de comunicação online como contas e listas de e-mail seguras e confiáveis - para pessoas e grupos de todo o mundo que trabalham por mudanças sociais.

Ainda conforme Santos, depois dos ataques de 11 de setembro aumentaram a repressão e a vigilância sobre os movimentos sociais e os meios de comunicação alternativos. A perseguição resultou na apreensão de servidores e do material coletado e na prisão de voluntários do CMI. O ativista norte-amaericano Brad Will foi assassinado por paramilitares no momento em que filmava uma revolta popular em Oaxaca, no México. As imagens feitas pelo militante compuseram o documentário "Brad Will - uma noite nas barricadas". A figura de Brad Will representa a entrega do ativista ao movimento social, o que reforça a distinção entre a mídia radical, a mídia convencional e a mídia meramente alternativa.

Os veículos de mídia radical regem-se pelo paradigma autonomista, segundo o qual o sujeito que transmite o fato não está dissociado do sujeito da ação. Logo, a ação comunicativa é uma ação política em que o comunicador reconhece-se na história como parte de um "nós". Na prática do CMI, essa particularidade da mídia radical reflete-se na diluição de movimentos sociais e coletivos de mídia nas atividades da rede, já que os ativistas de mídia independente pertencem a movimentos sociais e ativistas de movimentos sociais apropriam-se da rede de comunicação.No Brasil, Santos observa que o contato com movimentos sociais possibilitou o amadurecimento político dos voluntários do CMI. Para Elisa, oposicionamento claro ao lado dos movimentos sociais é um diferencial do CMI que o torna claramente tendencioso e parcial, diferente dos veículos corporativos que exaltam uma - falsa - imparcialidade. 


\begin{abstract}
"A maior parte das pessoas que são voluntárias do CMI é militante de algum movimento social. Às vezes o CMI fica sem voluntários porque eles vão todos para os movimentos sociais e isso é bom porque acaba sendo uma porta de entrada para outras lutas. A pessoa vem interessada em fazer a cobertura, se envolve com o movimento e acaba indo para o movimento. Às vezes as pessoas fazem o movimento contrário: o movimento precisa se fortalecer na comunicação e joga as pessoas para o CMI" (Elisa, entrevista, São Paulo, fevereiro de 2014).
\end{abstract}

A associação da mídia radical com os movimentos populares é um passo importante para a auto-organização dos ativistas envolvidos nas lutas sociais. No entanto, alguns coletivos do CMI enfrentaram problemas como a dificuldade de se obter autonomia financeira e a reprodução de valores burgueses como a competição, o individualismo e a hierarquização. O CMI Santiago, exemplifica Santos, tornou-se insustentável quando jornalistas independentes quiseram reduzir a mídia a um fim em si, e não à luta de classes. O risco da assimilação pelo capitalista é um risco que assombra qualquer mídia radical, pois o fetichismo em relação às tecnologias sociais pode inibir a reflexão e a crítica. O combate à ideologia pragmática da eficácia baseada na racionalidade instrumental é tão importante quanto a busca pela autonomia capaz de garantir a construção de bases materiais para o desenvolvimentos das lutas sociais sem a mediação do Estado e do mercado.

Elisa conta que, em São Paulo, a solidariedade, que segundo ela é a base da organização autônoma, reverte o problema da autonomia financeira. "Todo mundo se ajuda. O CMI nunca precisou pedir dinheiro pra nada. Não há necessidade de comprometer o caráter da organização para obter financiamento", garante. Embora isso às vezes possa atrasar o processo, a integridade do coletivo é mais importante. A definição do princípio do anticapitalismo, segundo Elisa, requer anos de estudo e discussão. $\mathrm{Na}$ opinião da ativista, os novos ativistas são os mais suscetíveis ao risco da assimilação capitalista. Quanto aos problemas enfrentados pelo CMI, Elisa cita a dificuldade de se manter uma plataforma de comunicação aberta anônima, devido ao aumento da vigilância, e a perda de "fôlego" diante do afastamento de militantes e do aparecimento de outras ferramentas mais avançadas tecnologicamente.Mas o site nunca saiu do ar, pois não pode ser hackeado, e continua a existir com os mesmos princípios. "Ele tem servido nesses anos todos como arquivo dos movimentos sociais", diz Elisa. A existência do CMI ainda se justifica num país onde a mídia tem o poder inegável de influenciar as decisões políticas. "Isso mostra o quanto é necessário ter veículos de comunicação alternativa que mostrem outra versão dos fatos", sustenta. 


\section{3- 2011, o ano das ocupações}

\subsection{1- Breve contextualização}

As redes digitais remodelaram o conceito de territorialidade e possibilitaram a conexão entre pontos geograficamente distantes.A interconexão mundial não esvaziou os espaços físicos, como os maispessimistas apontam, mas os elegeu um ponto de confluênciano qualse materializamreivindicaçõeslocais e globais.Essa vinculação entre redes de comunicação virtuais e manifestações nas ruas contra o capitalismo, concretizada na experiência da AGP, repetiu-se com igual ou maior força em 2011, ano em que ditaduras no Egito e Tunísia ${ }^{37}$ foram derrubadas e a crise financeira mundial quebrou a legitimidade dos governos ditos democráticos na Europa e Estados Unidos.

Decorrente do estouro da bolha imobiliária norte-americana em 2008 e da inadimplência fiscal de alguns países europeus, a crise financeira que assolou os países centrais do capitalismo corroeu o que restara do Estado de Bem-Estar Social na Europa. Sob pressão da Alemanha e do FMI, nações como Espanha, Grécia e Portugal tiveram que fazer cortes orçamentários na área de saúde, educação e serviços sociais a fim de preservar sua participação na zona do euro. Alves (2012) evidencia que a aplicação da política neoliberal de austeridade da troika (FMI, Comissão Europeia e Banco Central Europeu) pelos partidos conservadores não foi refutada pelos partidos hegemônicos da esquerda europeia. Segundo o autor, estavam postas as circunstâncias para a exacerbação da crise de legitimidade dos partidos da ordem burguesa, que se serviu da falência do pensamento crítico rendido ao pós-modernismo e ao neopositivismo.

Castells (2012) detalha o surgimento de um movimento na Espanha que decidiu contestar as soluções encontradas pelos governos e organismos neoliberais para contornar a crise europeia. A criação na rede socialFacebook do grupo "Democracia Real Ya" para debater a má administração da crise dava o primeiro passo para a formação de uma rede descentralizada de núcleos em diferentes cidades. A rede denunciava a democracia representativa vigente, na qual os partidos estavam a serviço dos banqueiros, e convocou os cidadãos a ocupar as ruas no dia 15 de maio sob o slogan

\footnotetext{
${ }^{37}$ As revoltas nesses países não serão abordadas porque não tiveram relação direta com o movimento de ocupação no Brasil, embora tenha de alguma forma alimentado a imaginação e a revolta dos ativistas.
} 
“Democracia Real Ya! Ocupe as ruas. Não somos mercadorias nas mãos de políticos banqueiros". O apartidarismo, a ausência de lideranças e o uso intenso das redes virtuais caracterizaram o grupo que ocupou a simbólica praça Puerta Del Sol, em Madrid, para discutir a democracia real noite a dentro, iniciando um movimento de ocupações - ou acampadas -de espaços públicos pelo mundo.

"Todos representavam a si mesmos, e as decisões ficavam a cargo da assembleia geral, que se reunia no fim de cada dia, assim como das comissões formadas em torno de cada tema sobre o qual as pessoas desejassem servir" (CASTELLS, 2013, p. 89). Os "indignados" ${ }^{38}$ faziam uso de espaços tanto físicosquanto virtuais, superando o bloqueio da mídia com uma forma de comunicação e organização autônoma, ou seja, sem intermediários políticos e midiáticos. Segundo Castells, o movimento não tinha um programa, pois, embora a crítica ao capitalismo fosse compartilhada por todos, "não havia consenso quanto ao tipo de economia que poderia proporcionar a todos empregos, moradias e condições de vida decentes" (idem, p.97). O desejo por uma democracia autênticamovia a experimentação de um modelo de democracia que prefigurasse a sociedade vislumbrada. Umacontrassociedade que materializasse os sonhos de uma verdadeira democracia. "Havia uma longa marcha a percorrer desde a negação do sistema até a reconstrução das instituições que iriam expressar a vontade do povo pelo processo de elevação do nível de consciência e deliberação participativa” (ibidem, p.99).

Castells cita algumas frases que compunham o discurso dos indignados, motivados pela construção da autonomia e pela conexão em rede: "Outra política é possível", "As pessoas unidas funcionam sem partidos”, “A revolução estava em nossos corações e agora enche as ruas", "Trazemos um novo mundo em nossos corações", "Não sou contra o sistema, o sistema que é contra mim". A ausência de lideranças fazia parte das novas relações sociais construídas pelo movimento. $\mathrm{O}$ autor não atribui o princípio da horizontalidade a um viés ideológico, mas à característica das redes virtuais. Porém, já foi pontuada nesta dissertação a inconsistência da interpretação que explica a forma de determinado movimento exclusivamente pela tecnologia utilizada por ele. Portanto, a demanda pela horizontalidade deve ser relacionada ao contexto histórico, social,

\footnotetext{
${ }^{38} \mathrm{~A}$ mídia popularizou o rótulo que alguns participantes haviam adotado, talvez inspirados pelo panfleto "Indignez-vous", publicado poucos meses antes pelo filósofo francês StéphaneHessel.
} 
econômico e político no qual o movimento está imerso. Assim, mesmo que não explícita, a influência do anarquismo, enquanto movimento e corrente ideológica que inclusive tingiu os ideais da Revolução Espanhola, não pode ser descartada.

Os norte-americanos não ficaram alheios ao clima de indignação. $O$ sistema financeiro dos Estados Unidos chegou à beira do colapso por conta da especulação imobiliária e da ganância dos seus administradores. Contaminados pelo lema "Unidos pela mudança global" - da manifestação global convocada pelos espanhóis para o dia 15 de outubro de 2011 - ativistas articulados em redes conclamaram a tomada das ruas com o apoio de organizações de base comunitária. No entanto, a revista de crítica culturalAdbusters de tendência anticapitalista - antecipou a manifestação quando postou no seu blog um convite: \#occupywallstreet no dia 17 de setembro, dia da assinatura da Constituição americana. O texto reproduzido por Castells chamava a população a unir a praça Tahrir com as acampadas da Espanha a partir de encontros físicos e assembleias populares virtuais. Com o objetivo de acabar com a influência do dinheiro sobre os políticos, formou-se um movimento múltiplo, cooperativo e descentralizado que levantou acampamento em Wall Street, "a maior corruptora da nossa democracia", "a Gomorra financeira da América” (ADBUSTERS apud CASTELLS, p.120).

De acordo com Castells, a propagação viral pela internet ajudou a espalhar o movimento geograficamente. Assim como a acampada espanhola, o Occupy Wall Street usou diferentes formas de comunicação para ligar espaços territorialmente localizados a espaços de fluxos, virtuais. Assim, a automediação também era um ponto marcante desse movimento híbrido. O uso das redes sociais, como Facebook,Twitter e Tumblr, serviu para a construção de narrativas, para a comunicação interna nos acampamentos e para conectá-los a outras ocupações. Com o auxílio da Internet, a palavra de ordem “ocupar" reverberou em centenas de cidades. No Brasil, onde aparentemente não se vivia crise alguma, acampadas foram organizadas. A seguir, a execução do movimento em São Paulo entrará em foco.

\subsection{2- Observações sobre o Ocupa Sampa}

Em São Paulo, estudantesatenderam ao chamado dos indignados espanhóis e organizaram o 15O, no dia 15 de outubro,fomentando a manifestação global cujas reivindicações mostraram raízes em comum.Com o lema "Arme a barraca e desarme o sistema",eles criaram o Ocupa Sampa e acamparam durante 43 dias no Vale do 
Anhangabaú, no centro de São Paulo.O Ocupa Sampa dizia-se um movimento anticapitalista, não-violento, apartidário, descentralizado e sem líderes. O voluntariado anônimo dominava o corpo de indivíduos que tomava decisões por consenso e se autoorganiza sob o slogan global "Não nos representa". Nas reuniões que anteciparam a acampada, o perfil apartidário refletiu na rejeição da presença de partidos políticos no acampamento. O coletivo reforça o princípio da democracia participativa e critica os prejuízos trazidos pelas imposições do mercado. Critica o sistema capitalista, porém não apresenta um substituto.

Assim como na Espanha e Nova Iorque, os acampados prezavam pela participação igualitária nas assembleias e manifestações, fazendo o uso do microfone humano - no qual a fala de uma pessoa era repetida por todos, em uníssono - em vez do megafone frequentemente usado por partidos e sindicatos. Outra semelhança entre os movimentos aqui e lá foi o uso da internet para garantir a autocomunicação, numa tentativa de revertera pouca atenção dada pela grande mídia. A edição de depoimentos e imagens captados pelos próprios militantes durante o acampamento deu origem a um documentário de quase uma hora de duração disponível para visualização na página do movimento no Youtube, na qual estão disponíveis vídeos da acampada. Nos primeiros minutos, uma das integrantes,cujo nome não é identificado,define o grupo:

\footnotetext{
No Ocupa Sampa, toda organização é auto-organizativa, ou seja, a gente se organiza a partir da autogestão. Significa que todas as pessoas têm papel importante na construção do espaço, das pautas, das reivindicações, do processo cotidiano. A gente preza por uma horizontalidade.
}

Para que as atividades do acampamento fossem realizadas com organização, criaram-se comissões responsáveis pela alimentação, comunicação, infraestrutura, recepção, limpeza e mediação de assembleias. A comissão de comunicação trabalhou em rede colaborativa e rotativa em que pessoas dentro e fora da acampada ajudaram a produzir o conteúdo do site. O endereço ocupasampa.milharal.orgorganiza o conteúdo e as atividades da mobilização, ondehá vídeos, fotos, manifestos, relatorias de assembleias, programação, artigos, cartas de solidariedade e uma rádio chat, na qual são transmitidas informações sobre as acampadas e os ciberativistas podem interagir. As hashtags associadas ao movimento - \#occupyworld, \#ocupeomundo, \#ocupabrasil - percorrem o sítio e aludem à sua inserção em um contexto internacional. O site está hospedado na plataforma Milharal, coletivo autônomo e anticapitalista que fornece gratuitamente 
serviços de comunicação online para movimentos, grupos e militantes que desejam a mudança social.

A adesão a plataformas colaborativas autônomas é uma forma empregada pelos ativistas para fugir do ambiente digital privado sem se desconectarem, mesmo que não abandonem a atualização de páginas no Facebook e Twitter. O sistema de blogs sociais e o provedor de e-mail autônomoRiseupsão meios de proteção à informação que circula entre os ativistas, pois têm como princípio não aceitar nenhum apoio financeiro de partidos, empresas e organizações não governamentais. Doações de ativistas são as únicas fontes de recursos permitidas para que as estratégias do movimento permaneçam em sigilo.

A produção do documentáriotambém colheu material dos acampamentos no Rio de Janeiro e Porto Alegre. Um participante da versão gaúcha da mobilização expressou o propósito do movimento:

O Ocupa Poa é um grupo de gente super inspirada que achou melhor
sair pra rua do que ficar em casa só na Internet reclamando das coisas,
reclamando de Belo Monte, da corrupção dos políticos. E resolveu sair
pra rua e tentar construir na praça um modelo de sociedade nova em
que as pessoas têm o poder, que não ficam esperando que os políticos
resolvam todos os seus problemas, que não acreditam mais em
Estado-babá nem na nossa democracia de voto de dois em dois anos
em que a nossa representatividade está completamente comprometida,
em que os nossos políticos não defendem os nossos direitos.

Um diálogo online entre os ativistas em São Paulo e os ocupantes no Rio de Janeiro reforçou a rejeição à entrada de partidos políticos na ocupação. Thiago, que participou da ocupação no Anhangabaú, conta $^{39}$ que PSTU e PSOL tentaram fazer parte do Ocupa Sampa, mas foram afastados. Segundo ele, foi durante as assembleias que o movimento se identificou como apartidário, consensual e não violento. Os partidos não foram os únicos a serem excluídos do acampamento. O Fora do Eixo, rede de coletivos que usa as redes digitais para divulgar produtos simbólicos como música e informação, também foi mantido longe "por conta da péssima experiência que tiveram com eles na Marcha da Liberdade". Para contextualizar o assunto, Thiago cita uma série de artigos ${ }^{40}$ publicada no Passa Palavra. Em meio a uma crítica à atuação do FDE, faz-se referência a outro texto $^{41}$ publicado no mesmo site que narra o episódio em que o coletivo se juntou aos

\footnotetext{
${ }^{39}$ Por meio de mensagem eletrônica enviada em 24 de abril de 2013.

${ }^{40}$ Disponível em http://passapalavra.info/2011/06/41431.

${ }^{41}$ Em http://passapalavra.info/2011/06/41221.
} 
organizadores da Marcha da Maconha. Durante as reuniões, Pablo Capilé, representando o Fora do Eixo enquanto seu principal articulador,responsabilizou-se pela divulgação do evento, além de votar pela mudança do nome para Marcha da Liberdade e sugerir o patrocínio da Coca Cola, desagradando grupos autônomos como o Movimento Passe Livre (MPL) e o Coletivo Desentorpecendo a Razão (DAR), próximos ao Ocupa Sampa. Assim, segundo o artigo, o Fora do Eixo teria esvaziado o conteúdo político da marcha, numa estratégia de mobilizar o capital simbólico do movimento, ou seja, "o prestígio de terem sido organizadores de tal movimento e de terem-lhe dado tal ou qual rumo, ou mesmo nenhum”.

$\mathrm{Na}$ tentativa de elaborar um pensamento, o Ocupa Sampa promoveu, transmitiu, gravou e disponibilizou na web debates públicoscom a participação de professores.Estiveram na acampada Raquel Roynik, que discutiusobre os megaprojetos em função da Copa do Mundo e das Olimpíadas, e VladimirSafatle, que sugeriu uma reflexão sobre a estrutura institucional. Segundo Safatle(2012), o Ocupa Sampa provou que era possível fazer circular uma ideia de outro lugar para mobilizar pessoas dispersas e diferentes em torno de uma noção central. O sociólogo emitiu opinião favorável ao movimento, dizendo que a ausência de propostas fechadas era uma virtude, pois permitia o exercício do pensamento em busca de respostas e alternativas possíveis. Ele critica a incapacidade da democracia parlamentar na defesa das populações, o que explica que "a alternância de partidos no poder não implica mais em alternativas de modelos de compreensão dos conflitos e polícias sociais" (SAFATLE, 2012, p.48). E complementa: "a angústia do desencanto que nos une, que faz com que o mesmo sentimento apareça em Túnis e São Paulo, Cairo e Nova York" (idem, p.51).

Na sessão de artigos do site do Ocupa Sampa, textos assinados por participantes da acampada defendem a ausência de proposições definidas. Em um desses artigos, um ativista chamado Marcio afirmou que " $O$ fato de nosso movimento não ser reativo, mas construtivo, o abre para uma infinidade de novas possibilidades". Em outro texto intitulado "Sobre a indecisão dos movimentos de ocupação", um autor anônimo expõe o descontentamento com a política organizada a partir de partidos e diz que a democracia direta não é uma utopia, mas algo que pode se tornar real. Para tanto, segundo ele, é preciso lutar para criar as condições necessárias, as quais não foram determinadas. 
No dia 23 de novembro de 2011, após 43 dias de ocupação com constantes abordagens policiais, o grupo seguiu para a Praça do Ciclista, na Avenida Paulista. Na madrugada do dia 26, a Guarda Civil Metropolitana e a Polícia Militar visitaram o acampamento. Munidos de uma decisão judicial questionada pelo grupo, a Tropa de Choque desmontou as barracas. Os manifestantes permaneceram na praça até o dia 3 de dezembro. Nos dias que se seguiram, houve ocupações de curta duração na praça Mahatma Ganhi e no Parque da Juventude. Neste último, que ocorreu de 21 a 25 de janeiro de 2012,aconteceram oficinas e debatessobre uma nova forma de vivência política. Durante esse período, o Ocupa Sampa participou de dois atos: um contra a especulação imobiliária no centro da cidade e outro contra a reintegração de posse da comunidade do Pinheirinho, em São José dos Campos. No dia 12 de fevereiro, o coletivo integrou um mutirão para arrecadação de produtos de higiene para as famílias despejadas.

Integrando outra onda de acampadas autoconvocada nas redes em maio de 2012, o Ocupa Sampa mobilizou-se para ocupar a Praça Charles Miller, zona oeste da capital paulista, durante quatro dias. O $12-15 \mathrm{M}$ foi antecedido por assembleias virtuais e presenciais para definir questões logísticas (armação de barracas, alimentação e transporte) e burocráticas (necessidade de liminar e/ou autorização da prefeitura), um grupo de trabalho responsável pelas estratégias de comunicação, a programação (palestras, atrações musicais, oficinas de arte) e o conteúdo do manifesto.O manifesto do $12-15 \mathrm{M}$ foi elaborado em conjunto por meio da ferramenta PiratePad, bloco de notas virtual no qual diversas pessoas podem escrever simultaneamente. O manifesto destaca a autonomia que, assim como a descentralização e o colaborativismo, é uma marca sobressalente do ciberativismo. Segue trecho do documento:

Temos como princípio a auto-organização e o autofinanciamento. Não aceitamos dinheiro de nenhuma empresa ou entidade que vise o lucro, seja ela qual for. O movimento tem autonomia diante do Estado, das empresas e de qualquer partido, mas respeita a participação destes.

O caráter independente do movimento se reflete na autonomia comunicativa. A possibilidade que o indivíduo tem de ser sua própria mídia o torna o único responsável por aquilo que publica, logo produz conteúdo com base em critérios próprios. A capacidade de autonoticiamento ficou clara durante a ocupação na praça Charles Miller no 12-15M numa tentativa declarada de driblar o silêncio da grande mídia. Os internautas puderam tomar conhecimento das atividades na página do Ocupa Sampa no 
Facebook e no Twitter, assim como as palestras que também foram transmitidas em vídeo.Embora não dispense o uso do Facebook e Twitter, o movimento procura não se distanciar da crítica às ferramentas de comunicação privadas. Além de reivindicarum regime público e gratuito de internet banda larga e uma legislação de direitos autorais que favoreça o compartilhamento, o Ocupa Sampa usa provedores de e-mail e sites especificamente voltados para movimentos sociais. No dia primeiro de setembro de 2012, os ativistas uniram-se ao coletivo Diabolô para aprender a libertar os computadores com a instalação de softwares livres.

É interessante comentar o envolvimento do Ocupa Sampa com movimentos sociais de luta pela moradia. $\mathrm{O}$ apoio à Frente de Luta pela Moradia, por exemplo, mostra a intenção de contribuir com a divulgação de mobilizações pelo direito de morar. Os sentidos de "ocupar" e "morar" cruzam-se na crítica às políticas públicas de habitação. A Ocupação Mauá, prédio abandonado no centro da cidade e agora ocupado por moradores de rua, foi um local frequente de encontros e concentração de atos. A participação no ato "Copa Pra Quem” junto com mais de cinquenta movimentos sociais no início de dezembro de 2012 fortaleceu a voz de famílias removidas por conta da realização das obras para o evento esportivo mundial que, segundo os protestos, tem provocado medidas elitistas e higienistas. No dia 9 de setembro de 2012,o movimento envolveu-se no ato de resistência em apoio às 85 famílias da Ocupação São João (sob ameaça de despejo) e às 92 famílias da Ocupação Ipiranga despejadas no mês anterior.

No segundo turno das eleições de 2012, o Ocupa Sampa promoveu o Churrasco da Justificativa, onde todos foram convidados a não votar. $\mathrm{O}$ evento reforçou $\mathrm{o}$ apartidarismo expresso nas palavras de ordem "Nossos sonhos não cabem em suas urnas" e "O povo unido governa sem partido". Dias depois foi inaugurado o Cineocupa, que exibiu o documentário mencionado acima. A atividade é fruto da colaboração entre membros do Ocupa Sampa e de outros coletivos. Os filmes são exibidos em ciclos temáticos no espaço cedido pelo "Tortura Nunca Mais", grupo que atua contra o esquecimento de pessoas torturadas e desaparecidas durante a ditadura militar.

Entretanto, a repressão policial nas últimas ocupações e a diminuição de participantes enfraqueceram o movimento. Em outubro de 2012, o Ocupa Sampa comemorou um ano da primeira acampada sem acampada. Dessa vez houve um panelaço global que levou manifestantes às ruas para invocar o direito à cidade e protestar contra a elitização do 
espaço urbano. Na capital paulista, o Ocupa Sampa organizou três dias de atividades. Houve oficinas de cartazes, rodas de conversa e música e um ato que aconteceu em várias partes do mundo simultaneamente. A marcha partiu do centro da cidade e foi tumultuada pela repressão policial.Apesar do fim do Ocupa Sampa em sua forma original, os ativistas continuaram participando de atos contra a ação da polícia militar na periferia, em defesa dos indígenas e da luta da população em situação de rua. Em agosto de 2012, o Ocupa Sampa fez uma vigília com o intuito de interromper a construção da usina de Belo Monte, no Pará. No dia 29 desse mês, quatro integrantes do grupo estiveram na plenária do Supremo Tribunal Federal, em Brasília, para protestar contra a derrubada da decisão judicial que paralisou a hidrelétrica.

\subsection{3- Tentativa de balanço}

Quanto aos indignados na Espanha e ao Occupy Wall Street, Alves (2012) enxerga que esses movimentos constituem densa e complexa diversidade social e exprimem a universalização da condição precária do proletariado - aliada à concentração de riqueza -característica das últimas três décadas de capitalismo neoliberal e intensificada com as crises financeiras. Conforme Alves, esses movimentos carregam uma profunda consciência moral e senso de justiça social. $\mathrm{O}$ uso das redes sociais, diz ele, ampliou a mobilização social e a área de intervenção territorial, produzindo sinergias sociais em rede.A luta contra o capital global que desterritorializa é a luta pela territorialização ampliada, difusa e descentrada (ALVES, 2012, p.33). Enquanto duram, os acampamentos transformam o cotidiano habituado a reproduzir as normas do capital em um espaço coletivo de reivindicação de direitos.

Porém, a crítica radical ao capitalismo que expôs as contradições impregnadas na ordem burguesa não foi além. Esvaziadas e reprimidas, as acampadas deixaram um legado.A cultura da autonomia foi fortalecida e revitalizada e, mesmo que não esteja mais em evidência, continua a ser construída subterraneamente. Castells avalia que as instituições democráticas foram desafiadas e a crença no capitalismo financeiro global foi abalada. A globalização dos de baixo - segundo Alves, em uma afirmação que lembra a máxima difundida pela AGP de que "a luta é global" - se contrapôs à globalização dos de cima. No Brasil, entretanto, a concretude da articulação dos de baixo foi questionada. 
Um artigo ${ }^{42}$ publicado pelo Passa Palavra diferencia o contexto europeu e norteamericano do contexto brasileiro. Nos Estados Unidos e Europa, a centralização do capital e o endurecimento dos critérios econômicos forneceram o substrato real das movimentações no Norte, pois desencadearam a queda no padrão de vida que retirou uma grande massa de pessoas - entre trabalhadores, desempregados e estudantes - da passividade. Enquanto que, no Brasil, o cenário econômico favorável - com taxas de crescimento significativas - dificultou a criação do clima de indignação visto nos países onde o movimento teve início. Segundo a publicação, isso tornou os objetivos das acampadas no Brasil caricatas e dispersantes. A presença massiva de jovens estudantes universitários revelou a inexistência de uma construção coletiva anterior, distanciando a ocupação de um movimento popular. Como não houve "a construção de uma ponte com o mundo do trabalho, com as empresas, com as periferias, com as escolas e faculdades, ou seja, com o mundo das pessoas comuns", as ocupações foram um "o maior movimento para o nada que se pode dizer que o movimento autônomo fez nos últimos anos".

\begin{abstract}
"Para se superar a onda de proclamações abstratas e dispersantes, é necessário fazer o caminho da politização, que consiste em inserir o problema específico no contexto geral, e não o inverso, como tem sido a tônica. Se queremos que o acampamento tenha uma boa consistência, uma longa duração e grandes consequências políticas, é imprescindível que o próprio acampamento seja resultado de lutas concretas, de assembleias e comissões democráticas realizadas previamente em locais de trabalho, em bairros, em escolas, ou seja, em locais onde o que é decisivo para a vida acontece" (PASSA PALAVRA, 2011).
\end{abstract}

O artigo também observa a fetichização do processo na ocupação organizada no centro de São Paulo, uma vez que grande parte do expediente de trabalho do movimento foi gasta com debates sobre a organização interna da acampada. As críticas do texto geraram discordâncias entre duas gerações de ativistas: os da AGP - dos quais muitos escrevem para o Passa Palavra - e os ocupantes de 2011, acusados por aqueles de terem dispersado um forte potencial de mobilização.Nos comentários, militantes do Ocupa Sampa e Ocupa Salvador discordaram das críticas e pediram a solidariedade dos veteranos. Caio Castor, que estava na ocupação do Anhangabaú, reconheceu que a expansão do movimento exige tempo e disponibilidade e questionou por que os militantes do Passa Palavra não ajudam os acampados a construir o trabalho de base. E

\footnotetext{
42،"Entre símbolos e ações simbólicas: os indignados e as acampadas”, disponível em http://passapalavra.info/2011/11/48056.
} 
conclui: "assumo nossas fraquezas, erros e contradições, mas também assumo a beleza de sermos eternos aprendizes".

Em outro artigo ${ }^{43}$ publicado no mesmo site, fez-se uma comparação entre a geração Seattle e a geração dos acampantes. Assinado por Manolo, o texto questiona os limites do uso da internet pelos coletivos. Na época da AGP, ele conta, a plataforma do Centro de Mídia Independente era acessada quase exclusivamente por ativistas envolvidos com os protestos, ficando o site desconhecido do resto da população. Outro problema observado nesse período foi a crescente dependência da comunicação digital, gerando o fenômeno da "adhocraciageek", ou seja, "de uma camada social detentora de conhecimento técnico em informática difusa por toda a "geração Seattle". Assim, ele reporta-se aos acampados indagando sobre os problemas de uma excessiva utilização desse meio de comunicação.

\section{A dependência de certa militância virtual que curte ou confirma participação nos acampamentos sem prestar-lhes qualquer outro apoio prático não arriscaria criar entre os acampantes expectativas de participação muito mais altas do que aquelas que são capazes de mobilizar?}

Mesmo com as críticas, o Ocupa Sampa procurou estar próximo, seja na web ou nas ruas, de coletivos autônomos e anticapitalistas. A interrupção das acampadas e outras atividades presenciais não impediu a manutenção das páginas nas redes sociais Facebook e Twitter, através das quais são compartilhadas publicações de movimentoscomo o Passe Livre, aquele que organizou e convocou, em junho de 2013, protestos contra o aumento da passagem de ônibus. As chamadas jornadas de junholevaram centenas de milhares de pessoas às ruas da capital paulista e estimularam protestos em diversas cidades brasileiras.As manifestações tornaram ainda mais explícitasa crise de representatividade no Brasil - que tem na Internet um forte meio de expressão - e a fragmentação da classe trabalhadora -decorrente da fase informacional do capitalismo-, refletindo conflitos historicamente enraizados nas sociedades ocidentais e gerando novos embates. Por isso, será necessário compreender como as manifestações que alteraram o cotidiano de diversas cidades brasileiras, especialmente em São Paulo, fortaleceram a articulação entre os movimentos autônomos a partir de estratégias políticas e comunicativas.

\section{4- As jornadas de junho em São Paulo}

\footnotetext{
43،“'A “geração Seattle' e a 'geração de acampantes"”, em http://passapalavra.info/2011/11/48007.
} 
De certa forma, a enorme proporção tomada pelas manifestações contra o aumento da passagem de ônibus obscureceu a trajetória do movimento que as idealizou. Conhecer um pouco das origens do Movimento Passe Livre (MPL) é importante para localizar o movimento no percurso do ativismo autônomo e relativizar o caráter espontâneo e pontual conferido às jornadas de junho. O MPL herda do movimento estudantil a histórica indignação com as tarifas do transporte público, expressa em protestos e "catracaços" promovidos pelo movimento estudantil. Um dos eventos que serviram de referência para a construção do MPL foi a Revolta do Buzu, série de atos em Salvador em 2003 que repudiaram o aumento da passagem. As manifestações tiveram ampla cobertura do Centro de Mídia Independente (CMI) e formaram um processo descentralizado, organizado a partir de assembleias realizadas nos próprios bloqueios das ruas (MOVIMENTO PASSE LIVRE, 2013). A insuficiência política das direções estudantis tradicionais que tentaram tomar a dianteira da revolta reforçou a necessidade de organizar um movimento autônomo e independente (POMAR et al., 2013).

Em 2004, o processo de formação do MPL deu outro passo significativo. A insatisfação com o aumento da passagem invadiu as ruas de Florianópolis, provocando as Revoltas da Catraca. Como narram Pomar et al. (2013), lançou-se a Campanha pelo Passe Livre de Florianópolis, frente formada, sobretudo, por jovens independentes que convocouum encontro nacional para articular as lutas. $\mathrm{O}$ encontro propõe a Campanha Nacional pelo Passe Livre e estipula o calendário nacional de lutas pelo passe livre. Em 26 de outubro de 2004, a lei do passe livre foi aprovada pela Câmara dos Vereadores de Florianópolis. Apesar da derrubada da lei no ano seguinte, a data virou o Dia Nacional de Lutas pelo Passe Livre. Durante o Fórum Social Mundial em janeiro de 2005, em Porto Alegre, estudantes independentes, dissidentes da esquerda partidária e ativistas ligados à Ação Global dos Povos fundaram o MPL, com apoio do CMI, baseado nos princípios de apartidarismo, horizontalidade e autonomia. Em 2006, o terceiro Encontro Nacional pelo Passe Livre elegeu o federalismo como outro princípio básico do movimento, criando uma rede de articulação nacional.

Surge então um movimento social de transportes autônomo, horizontal e apartidário, cujos coletivos locais, federados, não se submetem a qualquer organização central. Sua política é deliberada de baixo, por todos, em espaços que não possuem dirigentes, nem respondem a qualquer instância externa superior. (MOVIMENTO PASSE LIVRE, 2013, p.5). 
A passagem da reivindicação do passe livre estudantil à bandeira do passe livre para toda a população resultou do contato com as ideias de Lúcio Gregori, ex-secretário de transportes do governo de Luiza Erundina. Durante a gestão, entre 1989 e 1993, a então prefeita do Partido dos Trabalhadores (PT) propôs a tarifa zero, cujo subsídio viria do IPTU progressivo - medida que foi contestada pela elite paulistana e barrada na câmara municipal. Apesar da derrota, a defesa do transporte coletivo público e gratuito persistiu. O blog tarifazero.org, criado para fomentar o debate sobre mobilidade urbana e o direito à cidade, é uma das principais referências do MPL. A campanha pelo passe livre fundamenta-se na proposição de uma política de redistribuição de renda e justiça social que beneficie a maior parte da população, fazendo com que os mais ricos paguem mais impostos do que os mais pobres.

Segundo o MPL, essa proposta vem de uma crítica à lógica de circulação de valor na sociedade capitalista, que limita o trabalhador a sua condição de mercadoria, de força de trabalho. Fruto do modelo de sociedade em que vivemos, a exclusão urbana enrijece as catracas e suscita processos de resistência. A questão do transporte não é entendida de maneira isolada, mas como um problema transversal a diversas outras pautas urbanas. Por isso, o movimento realiza regularmente atividades em escolas, bairros, comunidades e ocupações, estabelecendo alianças com movimentos sociais de luta por moradia, saúde, etc. A retomada do espaço urbano é objetivo e método de um movimento que acredita que a ação direta se dá a gestão popular. Segundo Mayara ${ }^{44}$, militante do MPL em São Paulo, o trabalho orgânico e subterrâneo - ela prefere não usar o termo trabalho de base, pois pode inferir uma relação autoritária em que o intelectual mostraria o caminho ao "homem comum"- é essencial para o empoderamento popular. A não reprodução da relação de autoridade justifica-se pela intenção de ser autônomo na forma de organizar-se. O convívio horizontal permite a reflexão sobre os problemas de igual para igual, inflando assim o potencial revolucionário.

"A gente cresce se afirmando como algo novo", diz Mayara, explicando a ruptura do movimento com a esquerda tradicional. Esse distanciamento da forma de organização partidária e a valorização da ação direta e da horizontalidade revelam a influência do anarquismo. De acordo com a ativista, que já militou na Organização Anarquista Socialismo Libertário (OASL, antiga Federação Anarquista de São Paulo - FASP) e no

\footnotetext{
${ }^{44}$ A partir de notas tomadas durante a explanação de Mayara no debate intitulado "As jornadas de junho em uma perspectiva anarquista”, promovido pelo Centro de Cultura Social (CCS) em 23 de abril de 2014.
} 
Movimento dos Trabalhadores Sem Teto (MTST), através do movimento social - e não de uma organização político-ideológica- o MPL tem introduzido o anarquismo. "Penso anarquismo como demanda das pessoas", coloca. No entanto, ela se põe contrária ao fetichismo ideológico, lembrando que o anarquismo pressupõe a negação do anarquismo.

Nos primeiros anos de existência, o MPL avança pouco em termos de estrutura e organização porque, dentre outras razões, não consegue promover fóruns regulares a nível nacional, "embora se mantenha como uma rede de articulação que troca experiências e alimenta uma proposta avançada" (POMAR et al., 2013, p.13). Paralelamente ao desenvolvimento político do movimento, explodem no Brasil lutas relacionadas ao transporte, muitas delas sem a intervenção do MPL. Essa onda de mobilizações urbanas dá forma a um movimento maior composto majoritariamente por jovens com aversão aos meios institucionais e pouca relação orgânica com o passado.

\footnotetext{
"No entanto, atuam politicamente na sociedade e impactam uma nova realidade nos âmbitos dos municípios. Articulam-se em rede, em relações de poder mais horizontais. Dominam novas técnicas, sobretudo associadas à tecnologia, e sua linguagem política é menos engessada, se comparada aos grupos tradicionais de organizações de juventude de esquerda" (idem, p. 15).
}

Em 2011, a derrota e a repressão dos protestos contra o aumento da passagem anunciada pelo então prefeito de São Paulo Gilberto Kassab fizeram o coletivo paulista do MPL repensar suas estratégias. Com o início da gestão de Fernando Haddad (PT) em 2013, surgem os rumores de que a tarifa de ônibus e metrô vai aumentar de três reais para três e vinte. Então, sob o slogan "Se a tarifa não baixar, a cidade vai parar", o movimento elaborou uma campanha com menor duração e maior intensidade em relação às campanhas anteriores. Outra decisão consistiu na concentração no movimento da responsabilidade sobre as decisões estratégicas da luta. Assim, se evitaria a perda da autonomia e o desvio do foco das reivindicações.

A evolução da campanha do MPL pode ser acompanhada por sua página no Facebook. Em fevereiro, o movimento divulga atos contra o aumento da passagem em outras cidades como Goiânia e atividades sobre a questão do transporte em bairros periféricos de São Paulo. No dia 28, foi compartilhado um link do blog Tarifa Zero ${ }^{45}$ o blog é independente do site do MPL, embora dedique uma sessão às atividades do movimento

\footnotetext{
${ }^{45} \mathrm{http}: / /$ tarifazero.org/2013/02/28/sao-paulo-uma-faixa-de-protesto/
} 
- que direciona a um artigo assinado por um militante do movimento. O texto denuncia a situação precária da mobilidade urbana na região do Jardim Ângela e nas comunidades do Fundão da M'Boi Mirim, zona sul de São Paulo. Cobra-se o cumprimento da promessa feita por Haddad de duplicação da estrada do M'Boi Mirim e de construção de um novo terminal Jardim Ângela integrado a uma futura estação de metrô. A publicação termina com o seguinte recado: "Por um transporte verdadeiro público. Sem mobilidade não se vive na cidade. Não cruzaremos os braços. Só a luta muda a vida".

Das 690 pessoas convidadas, 96 confirmaram presença via Facebook na atividade aberta do MPL "por um transporte sem catracas", marcada para o dia 2 de março no espaço Tortura Nunca Mais, onde o Ocupa Sampa realizava exibições de filmes e debates. O evento foi pensado para discutir as implicações dos problemas do atual modelo de transporte na organização da cidade, sendo também um momento para apresentar o movimento, trocar experiências e trazer adesões à luta. O convite também é estendido aos que têm lutado contra o aumento da tarifa em outras cidades da Grande São Paulo, como Osasco, Mauá, Barueri e Cotia. Mais de um mês depois, dia 12 de abril, a imagem de cobertura da página do MPL no Facebook é alterada; nela, manifestantes seguram a faixa com a disseminada frase "Se a tarifa aumentar, a cidade vai parar". No dia 25 , quando começou o cadastramento de usuários no sistema do Bilhete Mensal, o movimento compartilhou um artigo publicado no Passa Palavra ${ }^{46}$ com reflexões sobre o projeto da gestão Haddad. Segundo o artigo, o projeto que visa gastar 400 milhões de reais para subsidiar a tarifa de que gasta no mínimo 140 reais por mês em transporte trata-se de um “investimento desigual dos recursos públicos que privilegia aqueles que possuem maior renda e, portanto, já têm maior acesso ao transporte público”.

Durante o mês de maio, o MPL São Paulo usou o Facebook para convidar o público a participar de eventos relacionados ao transporte e à luta contra o aumento da passagem. Para o dia 11, foi marcado um debate sobre as propostas de Haddad a fim melhorar o sistema de transporte. O local escolhido para discutir o assunto foi a Ocupação Mauá, prédio abandonado e habitado por pessoas que lutam pelo direito à moradia, onde estariam presentes uma urbanista e representantes do MPL-SP, do MTST e da União dos Movimentos de Moradia. No dia 16 de maio, é divulgada pela primeira vez a página

\footnotetext{
${ }^{46}$ Disponível no endereço eletrônico http://passapalavra.info/2013/04/75693.
} 
do evento do primeiro grande ato contra o aumento da tarifa, marcado para o dia 6 de junho. Com 46 compartilhamentos, a publicação assinala que a cobrança de tarifa, assim como o aumento do preço, é uma "escolha política pela exclusãoque só beneficia os cofres dos empresários de ônibus" e reforça a preferência pelo investimento em obras viárias que beneficiam os carros.Uma festa de arrecadação para a luta contra o aumento foi agendada para o dia 24, na Faculdade de Filosofia, Letras e Ciências Humanas (FFLCH) da USP. Além de informar a participação da Fanfarra do MAL, movimento autônomo libertário que batuca durante os protestos, a página do evento anuncia os protestos de junho e finaliza afirmando que "se não é possível dançar, não é nossa revolução", frase imortalizada pela anarquista Emma Goldman. Para o dia 27, outra atividade aberta do MPL foi marcada, dessa vez no espaço autônomo Casa Mafalda. No dia 27 de maio, a página do MPL informa a primeira manifestação contra o aumento da tarifa. Segundo a publicação que divulgou mais de 40 fotos do ato organizadopelo MPL, estudantes de uma escola estadual invadiram o Terminal Pirituba, reunindo cerca de 150 pessoas animadas pela Fanfarra do MAL que seguiram em passeata para a subprefeitura.

O mês de junho começou com a divulgação de um protesto na Estrada do M'Boi Mirim, em que moradores da região travaram a via com pneus, e da planfetagem contra o aumento no Terminal Campo Limpo, disseminando o grande ato do dia 6. No dia 4, a página do Facebook da Rede de Comunidades do Extremo Sul, movimento popular criado na zona sul de São Paulo com o objetivo de organizar de maneira autônoma a periferia, divulgou uma nota publicada no site da rede ${ }^{47}$ em que critica o aumento da passagem e apoia os protestos. No dia 5, o MPL difundiu o ato que organizou junto a alunos do ensino público estadual no bairro da Vila Leopoldina. A manifestação terminou com uma assembleia que deliberou as próximas ações. No mesmo dia, a página da Casa Mafalda no Facebook compartilhou um vídeo publicado pelo Ocupa Sampa que faz um chamado para o ato do dia 6.

Uma pesquisa da Interagentes ${ }^{48}$ dirigida por Pimentel e Silveira (2013)monitorou citações públicas no Facebook relativas aos dias de protestos. Tomando a página ou perfil no Facebook como um vértice ou nó, definiu níveis de HUB, o número de

\footnotetext{
${ }^{47} \mathrm{http} / / /$ redeextremosul.wordpress.com/2013/06/04/o-transporte-publico-e-as-lutas

${ }^{48}$ Empresa de comunicação digital especializada em monitoramento, ações de intervenção e articulação de redes.
} 
compartilhamento de posts de outros perfis, e de Autoridade, quantidade de posts próprios replicados. O acompanhamento das páginas dos atos no Facebook demonstra o processo de evolução dos protestos, permitindo uma análise do alcance comunicativo de cada evento. A página do ato do dia 6 atingiu 20.500 confirmações de presença. A manifestação partiu do Teatro Municipal e provocou a interdição de vias importantes da cidade, onde se deram confrontos entre manifestantes e polícia militar. Com saldo de 15 manifestantes detidos e 8 feridos, o ato teve uma cobertura midiática que partilhava do mesmo pensamento que o comando da operação policial:a desqualificação da manifestação, classificando-a como baderna. "Neste dia nossas buscas encontraram cerca de 10.500 mensagens públicas no Facebook" (PIMENTEL; SILVEIRA, 2013). A página do Estadão no Facebook foi a que teve maior autoridade da movimentação nas redes, seguido pela página do Passe Livre São Paulo. A página da Mídia Ninja, projeto de mídia independente ligado ao Fora do Eixo - que tem conflitos com movimentos autônomos como o MPL- também teve destaque, assim como a da revista Carta Capital.

Em meio à hostilidade da grande mídia e do governo do estado, foi mantido o segundo grande ato, no dia seguinte, 7 de junho. $\mathrm{O}$ dia começou com a repercussão do comentário feito pelo apresentador do telejornal local Bom dia São Paulo, da TV Globo. Após da exibição de uma reportagem claramente depreciativa, o jornalista Rodrigo Bocardi observou, ironicamente, que alguns dos manifestantes não têm $R \$ 3,20$ para pagar a passagem, mas têm $\mathrm{R} \$ 3$ mil reais para pagar a fiança. A polêmica gerada pelo comentário nas redes sociais tematizaram uma matéria publicada pela Folha ${ }^{49}$,compartilhada pela página do Passe Livre São Paulo no Facebook. Ao final do post, que teve 657 curtidas e 154 compartilhamentos, o movimento refez o convite ao ato, copiando o link do evento que obteve 6.200 confirmações.

O blog do Rizoma Tendência Libertária, coletivo autônomo formado por estudantes da USP, publicou um cálculo que chegou à conclusão de que em quatro minutos e trinta segundos, o metrô ganha $\mathrm{R} \$ 73.386,67$. $\mathrm{O}$ ato levou mais de 5 mil pessoas, segundo a polícia, às ruas e foi marcado pela reação de militantes blackblocks à repressão policial. A pesquisa do Interagentes encontrou aproximadamente 17.000 mensagens públicas no dia 7. Curiosamente, a página do Passe Livre caiu da segunda para a sétima posição na

\footnotetext{
${ }^{49} \mathrm{http} / / / \mathrm{f5}$.folha.uol.com.br/televisao/2013/06/1291282-comentario-de-apresentador-do-bom-dia-sp-gerapolemica-na-internet.shtml
} 
escala de Autoridade, enquanto que as páginas do Estadão, da Carta Capital e da Folha figuraram entre as primeiras posições.

No dia seguinte, uma publicação do MPL no Facebook rendeu 925 compartilhamentos. Após exaltar os $226 \mathrm{~km}$ de congestionamento e as interdições de avenidas, o movimento diz que "terça [dia 11] vai ser maior". No dia 9, uma nota pública do Passe Livre foi difundida na rede social. O texto enfatiza que o MPL não se considera o dono da luta contra o aumento, por isso não tem controle total das manifestações nem dos grupos envolvidos. A nota reforça o caráter independente e apartidário do movimento e rejeita suposições publicadas por veículos de imprensa de que partidos políticos fariam parte do MPL. Além de destacar a ausência de lideranças, característica que muitos editores e intelectuais não conseguiram - ou não quiseram - assimilar, a nota comentou uma entrevista que o prefeito Haddad concedeu ao jornal Estado de São Paulo. O movimento rebateu o argumento dado pelo prefeito de que a revogação do aumento da passagem seria inevitável, declarando que não está disposto a negociar algo que não seja a revogação do aumento. A nota também chama atenção do governador Geraldo Alckmin para o fato de que as mobilizações se estendem para o aumento da passagem de trem, metrô e intermunicipais, pois os "mesmos prestam um serviço de péssima qualidade ao usuário e precarizam as condições de trabalho de seus funcionários".

No dia 10, véspera do terceiro ato, a página do movimento continuou a repercutir matérias sobre o ato publicadas pela mídia corporativa. A notícia saída na Folha em que Haddad defende a ação da PM e diz que só negocia se o movimento "renunciar à violência" desagrada o MPL, que ressaltou que a violência foi iniciada pela polícia. A página virtual também divulga fotos tiradas dos protestos organizados por moradores e estudantes do Jardim Mirna, na zona sul, e sugere que a população organize outros protestos paralelos. No Facebook, o evento do terceiro ato consegue 13 mil confirmações de presença, já nas ruas o protesto reúne 15 mil pessoas. A repressão endurece, estimulando a disseminação, por vídeos e relatos pessoais, da truculência da polícia. Uma campanha de arrecadação foi feita por um site de financiamento coletivo para ajudar a pagar a fiança dos mais de duzentos detidos. Conforme a avaliação de mais de 140 mil mensagens publicadas no Facebook, a pesquisa da Interagentes identificou, nesse momento, a percepção dos usuários da rede social em relação aos protestos era majoritariamente positiva. Pimentel e Silveira (2013) também detectaram que, no dia 11, a página do Passe Livre ocupou o terceiro lugar do ranking de 
autoridades, ficando novamente atrás do Estadão. Abaixo, mas ainda em destaque, a página da Mídia Ninja e da Folha de São Paulo.

No dia 12, um post do Mães de Maio, movimento independente que denuncia a violência policial nas periferias, esbraveja: "Vandalizam as nossas vidas há mais de 500 anos, e somos nós os vândalos?". A publicação compartilha uma matéria do UOL ${ }^{50}$ sobre os prejuízos que o aumento da tarifa pode trazer aos paulistanos de baixa renda e declara apoio ao MPL.

Do lado da mídia impressa, o tratamento aos manifestantes continua depreciativo. Nos editoriais do dia 13, Folha e Estadão ${ }^{51}$ pedem maior repressão policial, deslegitimando as reivindicações dos "vândalos" e "baderneiros" que têm atrapalhado a vida dos paulistanos. Segundo o editorial da Folha, a ideologia que move o MPL, qualificado de grupelho marginal e sectário, é "pseudorrevolucionária" e a bandeira do passe livre é "irrealista". Em resposta, o MPL publica um artigo intitulado "Por que estamos nas ruas" na seção Tendências e Debates do jornal ${ }^{52}$, em que aponta a exclusão social gerada pelo sistema de transportes e acusa a repressão policial de provocar uma revolta popular. A nota do movimento, publicada no site e página no Facebook, sobre a situação dos presos do último ato foi reproduzida pelo portal do jornal Brasil de Fato e pelo blog Viomundo ${ }^{53}$.

O evento da manifestação do dia 13 no Facebook teve 28 mil confirmações de presença. Durante o quarto ato, o MPL narra a tomada das ruas por mais de 10 mil pessoas e relata a postura agressiva da tropa de choque. Nas redes sociais e quase em tempo real, circularam depoimentos sobre prisões, violência e abuso policial. A percepção em relação aos protestos manteve-se em grande parte positiva, segundo a Interagentes, enquanto que as mensagens críticas aos atos referem-se aos episódios de depredações taxados de vandalismo. Se no dia 13 foram detectadas 45 mil mensagens públicas no Facebook, no dia seguinte esse número saltou para 125 mil. Ainda de acordo com a Interagentes, a página do Estadão permanece liderando a lista de autoridades e a página

\footnotetext{
${ }^{50} \mathrm{http}$ //noticias.uol.com.br/cotidiano/ultimas-noticias/2013/06/12/aumento-de-r-020-na-passagem-obrigapaulistanos-de-baixa-renda-a-pular-refeicoes-e-arrumar-bicos.htm

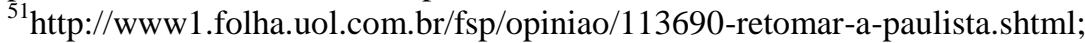
http://www.estadao.com.br/noticias/impresso,chegou-a-hora-do-basta,1041814,0.htm ${ }^{52} \mathrm{http}: / / \mathrm{www} 1$. folha.uol.com.br/fsp/opiniao/113691-por-que-estamos-nas-ruas.shtml

${ }^{53}$ Disponíveis em http://www.brasildefato.com.br/node/13230 e http://www.viomundo.com.br/denuncias/nota-publica-do-passe-livre-sobre-a-situacao-dos-manifestantespresos.html .
} 
do MPL cai para décima terceira posição. Pomar et. al. (2013) analisam que as cenas explícitas do abuso policial que vitimou manifestantes e profissionais da imprensa abalaram o discurso contrário às manifestações, deslocando o eixo temático da questão da tarifa para o direito de se manifestar.

\begin{abstract}
Nota-se, sobretudo, uma mudança no discurso dos meios em especial de duas maneiras: eles param de identificar o movimento com os partidos políticos da extrema-esquerda; e, adicionalmente, sugerem que sob a insatisfação com o preço das passagens escondem-se muitas outras insatisfações (POMAR et al., 2013, p.139)
\end{abstract}

Enquanto veículos de comunicação que condenavam as manifestações passam a interpretá-las como uma ampla crítica à política e ao Estado brasileiro, o MPL e grupos aliados tentam frisar a revogação do aumento da passagem como a única pauta. No dia 14, a página do movimento no Facebook informa sobre o "Copa para Quem?", ato unificado do Comitê Popular da Copa 2014 em SP, formado por mais de 80 organizações, entre as quais estão o MPL, Casa Mafalda e MTST. Além disso, o movimento divulgou fotos e vídeos que mostram a truculência policial e confirma o ato do dia 17 de junho. Chegado o dia do quinto ato, o grupo Mães de Maio compartilha entrevista concedida por um integrante do MPL ao site do jornal Brasil de Fato ${ }^{54}$. O ativista ressaltou que o motivo central do movimento continuava sendo a redução das tarifas e a melhoria do transporte como um todo. O evento do ato do dia 17 teve 215 mil confirmações no Facebook, 14 vezes mais do que no primeiro ato. A página do coletivo Desentorpecendo a Razão (DAR), defensor da legalização das drogas e da desmilitarização da polícia, publica: "Largo da Batata tomado! O grito que ecoa? 'O povo unido não precisa de partido!'\#revogaaumento, \#passelivre”.

Apesar dos esforços do MPL e seus parceiros para preservar a centralidade da pauta, as centenas de milhares de pessoas nas ruas mostraram a dispersão e a pluralização temática dos protestos. Faixas e cartazes explicitaram que a reivindicação não era só por 20 centavos, mas também pelo direito à educação e saúde e pelo fim da corrupção. Prova desse desvio temático foi a presença da página do "Movimento Conta a Corrupção" no primeiro lugar no ranking de autoridades nas redes sociais, conforme monitoramento feito pela Interagentes. A crítica aos políticos corruptos foi bem aceita pela grande mídia conservadora que, numa manobra discursiva, responsabilizou o governo da presidente Dilma Roussef pela insatisfação popular. As imagens de

\footnotetext{
${ }^{54}$ http://www.brasildefato.com.br/node/13259.
} 
manifestantes de verde e amarelo cantando o hino nacional alimentaram o que alguns observadores chamam de guinada à direita ou "coxinização".

No dia 18, a disputa simbólica pelo significado das manifestações continuou intensa. Assim como o motivo dos protestos, o juízo acerca da tática blackblock de depredações de lojas e agências bancárias dividiu os manifestantes. Na tentativa de contornar o espetáculo midiático em torno da pluralidade das manifestações, o MPL publicou outra nota pública em que, mais uma vez, ratifica que a revogação do aumento é "o motor das mobilizações e o fator de união entre os diversos manifestantes". No fim, insiste: "não sairemos das ruas enquanto a tarifa não baixar".

A página do movimento Mães de Maio somou-se às vozes que gritavam nas ruas e redes sociais "o povo não é bobo, abaixo a Rede Globo" ao compartilhar um artigo publicado no blog Bola e Arte ${ }^{55}$ intitulado "Não se iludam, a ultradireita está querendo se aproveitar das manifestações populares no Brasil". Além disso, afirmou:"a Globo está fazendo um enorme esforço para fortalecer a parte mais atrasada e preconceituosa dos protestos e colocá-la contra os setores populares, radicais e consequentes (consequentes porque são radicais, porque entendem a raiz dos problemas: a sociedade capitalistaracista)". Ainda no Facebook, a página do Ocupa Sampa corroborou relatando o percurso do sexto ato do dia 18: "movimento autônomo, não nacionalista e patriota, seguindo para o Terminal Parque Dom Pedro. Pela revogação imediata! Nem pátria, nem patrão. Horizontais, apartidários, autônomos, corram pra lá" - o vídeo "Direita, de carona não!"56 reforça a tentativa de evitar o conservadorismo. Por sua vez, a Casa Mafalda sugere que, para contrastar, "todo mundo que não é coxinha" vá de preto, com cartazes com os dizeres "nem hino nem bandeira, a luta é por um mundo sem catracas e sem fronteiras".

Mesmo com o anúncio oficial da revogação do aumento das tarifas do transporte público no dia 19, o Passe Livre São Paulo manteve o ato do dia seguinte, com o intuito de comemorar a redução da passagem e prestar solidariedade às lutas das demais cidades do país e aos presos, detidos e processados durante os atos. No dia 20, o movimento exalta que "só a luta dos de baixo pode derrotar os interesses impostos de cima". Diz também que não foi o MPL que barrou o aumento, mas o povo. "A

\footnotetext{
${ }^{55}$ http://bolaearte.wordpress.com/2013/06/18/nao-se-iludam-a-ultra-direita-esta-querendo-se-aproveitardas-manifestacoes-populares-no-brasil

${ }^{56} \mathrm{https}: / / \mathrm{www}$.youtube.com/watch?v=HGIIREwiSTw
} 
derrubada do aumento é um passo importante para a retomada e a transformação dessa cidade pelos de baixo". Conclui afirmando que a caminhada do movimento continua rumo ao passe livre. "Se agora eles dizem que a tarifa zero é impossível, nossa luta provará que eles estão errados”. No entanto, a página do MPL no Facebook perdeu força. À noite, na avenida Paulista, enquanto a maioria desfilava sorrindo, de verde e amarelo, uma minoria carregava bandeiras negras e marchava seriamente ao som da Fanfarra do Mal. A pesquisa da Interagentes (PIMENTEL; SILVEIRA, 2013) encontrou 300 mil mensagens públicas trocadas no dia 20 e observa que a página do Passe Livre deixou de figurar na lista das 20 maiores autoridades.

O MPL saiu das ruas, uma vez que seu objetivo imediato tinha sido alcançado, mas continuou com seu trabalho orgânico em comunidades e escolas periféricas. O movimento aproveitou a visibilidade das manifestações para ganhar novas adesões. No dia 21, o MPL usou a rede social para comunicar três atividades abertas em que as origens, princípios, reivindicações e métodos de trabalho seriam apresentados. As três atividades aconteceram simultaneamente em três regiões diferentes da cidade. Movimentos de luta por moradia, que nunca tiveram onde dormir, abasteceram-se da vitória da luta contra o aumento da tarifa e divulgaram, através da página da Rede de Comunidades do Extremo Sul ${ }^{57}$, um protesto no Grajaú, zona sul de São Paulo. "Foi pacífico e demos nosso recado. 20 centavos é só o começo. A luta continua! Todo poder ao povo!", disse o texto acompanhado da imagem de manifestantes erguendo a faixa "Somos gregos, turcos, mexicanos. somos sem pátria. Somos revolucionários".

A publicação foi direcionada a uma postagem do blog da rede que informa o levantamento de vinte acampamentos na região com o intuito de criticar a carência de moradias decorrente da onda de despejos e da falta de política habitacional. Em seguida, a rede propõe a unificação de todos os movimentos da periferia na luta por moradia, e enaltece que "a terra deve ser de quem precisa dela para produzir e viver, e não para quem quer especular e lucrar com o sofrimento alheio. Se morar é um direito, ocupar é um dever". Um vídeo mostra a caminhada de cerca de 100 manifestantes até a subprefeitura de Socorro. Chegando lá, os portões são abertos pela guarda e no interior do prédio ocorre uma reunião com a subprefeita e o chefe de gabinete. Dentre as reivindicações feitas, destacam-se a cessão ou venda pelo governo dos terrenos

\footnotetext{
${ }^{57}$ http://redeextremosul.wordpress.com/2013/07/04/a-esquerda-e-as-lutas
} 
ocupados, o impedimento da repressão policial e um encontro com a secretaria de habitação e a Caixa Econômica Federal, órgão responsável pelo financiamento da construção de casas populares. As autoridades apoiaram o movimento, elogiando sua ação pacífica, e se comprometeram a concretizar seus pedidos.

Na última semana de junho, a página do MPL-SP no Facebook divulgou atos de movimentos por moradia, atividades como uma aula pública sobre tarifa zero e a primeira edição do Central Autônoma, programa de rádio disponibilizado na $\mathrm{web}^{58}$, que trouxe entrevista com um ativista do Passe Livre. Na gravação do boletim semanal idealizado pelo Coletivo Autônomos FC, que tem integrantes que também atuam na Casa Mafalda, o militante frisa que "o MPL se coloca dentro do campo de esquerda deste processo". A rede social também foi usada para difundir outro ato "Copa pra quem? Pela desmilitarização da polícia”, organizado pelo Comitê Popular da Copa, que aconteceu no dia da final da Copa das Confederações.

Foram muitos os esforços em analisar os porquês, descaminhos e legado das jornadas de junho. Frederico (2013) observa que a adesão de sujeitos periféricos aos protestos conferiu à luta traços de uma revolta popular. "O Brasil acordou, mas a periferia nunca dormiu", dizia um cartaz de um manifestante. No entanto, a visibilidade obtida pelos protestos com a rápida e crescente disseminação de informações nas mídias acabou levando às ruas pautas difusas que descaracterizaram o apelo anticapitalista da reivindicação inicial. "Essa multidão de indivíduos solitários, moldados ideologicamente por décadas de hegemonia do neoliberalismo, fazia, assim, a sua estreia na vida pública" (FREDERICO, 2013, p.20). O autor aponta como consequências da ofensiva neoliberal iniciada nos anos 1990 a concentração de renda, a favelização, o enfraquecimento do movimento operário e a fragmentação da classe trabalhadora. Embora faltasse aos manifestantes o reconhecimento enquanto classe social, o sociólogo Ricardo Antunes (2014) vincula os protestos ao proletariado do setor de serviços formado por jovens trabalhadores precarizados. Antunes salienta que as condições precárias de trabalho contrariam o "mito do país padrão Fifa", referindo-se à formação do precariado, grupo social marcante do atual regime de acumulação pósfordista definido por Braga (2013) como:

a massa formada por trabalhadores desqualificados e semiqualificados que entram e saem rapidamente do mercado de trabalho, por jovens à

\footnotetext{
${ }^{58} \mathrm{https}: / /$ soundcloud.com/centralautonoma/central-autonoma-1-28-06-2013
} 
procura do primeiro emprego, por trabalhadores recém-saídos da informalidade e por trabalhadores subremunerados (BRAGA, 2013, p.7)

Aspectos do capitalismo a nível mundial encontram-se com o momento político brasileiro. Não por acaso, um movimento apartidário que critica a burocracia e o autoritarismo de organizações políticas tradicionais desencadeou uma onda de protestos num país que vive em crise com as instituições da democracia representativa. Essa crise de representatividade atingiu seu extremo quando manifestantes com bandeiras de partidos foram agredidos e expulsos dos protestos, revelando a frustração com o governo de um partido que nasceu de uma crítica social estrutural, mas se tornou um gestor de questões sociais com vistas ao sucesso eleitoral. Sobre a chegada do Partido dos Trabalhadores (PT) ao poder, Oliveira (2013) comenta:

"Quando este "novo" na política se dissolve no jogo da realpolitik da
máquina do Estado brasileiro, marcado e percebido pela sociedade por
uma estrutura de manutenção de privilégios da tradição
patrimonialista da sociedade brasileira, gera a desilusão com a política
exercida por meio da mediação partidária"(OLIVEIRA, 2013)

Segundo Oliveira, a mídia hegemônica também está entre as instituições mediadoras clássicas da sociedade liberal que perderam prestígio. Ao permitir que todos sejam potencialmente protagonistas da produção de informações, a Internet semeia uma nova esfera pública marcada pela autorrepresentação, que indica sentimento de anarquismo, mas também é apropriada pela direita. Como foi visto, num determinado ponto da jornada de junho os meios de comunicação desviaram o foco original das manifestações para o julgamento moral da corrupção, tratada não "como produto de uma relação promíscua entre o capital e o Estado, mas apenas no pretenso caráter do ocupante do cargo público", afirma Oliveira. Frederico assinala que a incorporação dos protestos ao "partido da mídia", isto é, ao partido da sociedade do espetáculo provocou a estetização da política - alimentada tanto pelos coxinhas quanto pelos Black blocks. Estes, adeptos da tática de depredação de símbolos do capitalismo como uma forma de denunciar o sistema que os violenta diariamente, foram exaustivamente taxados de vândalos, delinquentes, baderneiros, etc. Assim, a ilusão de uma Internet democrática confrontouse com a colonização dos espaços digitais pela vigilante e controladora ordem capitalista. Conforme Frederico:

\footnotetext{
${ }^{59}$ OLIVEIRA, DENNIS. "A primavera 'invernal' brasileira: uma esfera pública radical em disputa”. No prelo.
} 


\begin{abstract}
“A substituição de uma pauta unificada por reivindicações esparsas impediu que se atacasse a essência dos problemas ficando-se, por assim dizer, na periferia, ou melhor, em suas manifestações visíveis, cultivando um fazer político performático bem ao gosto do pósmodernismo, que, no lugar da palavra, da argumentação persuasiva, prefere o culto da imagem" (FREDERICO, 2013, p. 26)
\end{abstract}

Contudo, a manipulação midiática não foi capaz de eliminar totalmente a pauta introduzida pelo MPL. O problema da mobilidade urbana nas grandes capitais brasileiras tem desencadeado muitas lutas em defesa do direito à cidade e, especialmente em São Paulo, os habitantes estão imersos no que Chauí (2013) denominou "inferno urbano". A estruturação de um sistema viário voltado ao automóvel e aos interesses privados é irmã da explosão imobiliária baseada na especulação. $\mathrm{O}$ mercado imobiliário legal exclui a força de trabalho barata (MARICATO, 2013, p.14), expulsando moradores de regiões centrais para zonas periféricas em precárias condições de infraestrutura. Os megaeventos trazidos sob aplausos da elite empresarial para o Brasil valorizam ainda mais a cidade não apenas como espaço de reprodução da força de trabalho, mas também como um produto lucrativo - resultado das contradições desse processo de valorização é a formação de entidades como o Comitê Popular da Copa.

Harvey pontua que o capital lida com a questão da moradia com preconceito de classe, sendo a urbanização dominada pela dinâmica do acúmulo de capital. Segundo ele, o projeto político anticapitalista deveria mover-se para construir uma sociedade em torno do seu valor de uso, e não do valor de troca. A luta de classes está implícita nos movimentos sociais da cidade que indicam as falhas da oligarquia dominante no atendimento das necessidades dos trabalhadores. ${ }^{60}$ De acordo com Harvey, o direito à cidade "demanda um esforço coletivo e a formação de direitos políticos coletivos ao redor de solidariedades sociais" (HARVEY, 2013, p.10). A variedade de iniciativas locais que florescem "são muito mais consistentes com uma imagem de socialismo descentralizado ou de um socialismo anarquista do que de um planejamento e controle centralizados e estritos" (idem, p.11).

Do ponto de vista do movimento autônomo, Pomar et al. (2013) avaliam que as jornadas de junho significaram a vitória da luta direta e deixaram dois legados opostos: "o da mais extrema dispersão processual e o da fértil conjugação de processo e resultado na luta contra o aumento" (POMAR et al., 2013, p. 227). Prioritariamente valorizada nos movimentos horizontais e autônomos das duas últimas décadas, a dimensão

\footnotetext{
${ }^{60}$ Disse David Harvey durante conferência no Centro Cultural São Paulo, em 26 de novembro de 2013.
} 
processual constrói-se a partir de "experiências vivas de uma democracia comunitária e espaços de autoexpressão contracultural" (idem). Trata-se do pensamento caro aos autonomistas de que é o movimento que muda a sociedade ao transformar as relações sociais. Para tanto, a estrutura interna da organização precisa ser a gênese do futuro socialista, uma forma de comunismo pré-figurativo.

A grande ênfase depositada nos processos pode encobrir a falta de uma estratégia clara, como foi o caso da Ação Global dos Povos, que acreditava que barrar a reunião da ALCA era um passo para destruir o neoliberalismo. Com os protestos de junho, o MPL demonstrou que, mesmo com a dispersão da pauta e a ausência de um horizonte ideológico comum, foi possível combinar "a valorização da criatividade e da democracia no processo de luta com a incorporação de um entendimento maduro de que a política se mede por resultados" (ibidem, p.234). A capacidade de fazer política que não aconteceu no ciclo de lutas dos anos 1970 foi um ganho das jornadas de junho, uma vez que o MPL não permitiu que o medo de ter seus ideais anticapitalistas comprometidos o impedisse de dialogar com a imprensa empresarial e com o poder público. O radicalismo que imobiliza deu lugar a uma lógica de luta voltada para a ampliação de direitos que, devidamente desdobrada, remete à tarifa zero e à desmercantilização do transporte para todos.

O salto estratégico dado pelo MPL foi reconhecido por outros grupos autônomos. O coletivo Desentorpecendo a Razão (DAR) publicou em setembro de 2013 em seu site uma entrevista $^{61}$ com Pablo Ortellado, que militou na AGP e hoje é professor da USP, em que ele comenta que a experiência do Passe Livre São Paulo foi um aprendizado para o movimento autônomo no Brasil e no mundo. Em outra publicação ${ }^{62}$, o DAR divulgou em carta aberta o orgulho de dividir as ruas e princípios com o MPL. Lembrando momentos da articulação entre movimentos autônomos como "as movimentações que desaguaram no Ocupa Sampa”, o DAR enalteceu o fortalecimento de grupos e coletivos autônomos, "sinalizando para a construção de um mundo onde finalmente caibam muitos mundos".

\footnotetext{
${ }^{61}$ http://coletivodar.org/2013/09/pablo-ortellado-experiencia-do-mpl-e-aprendizado-para-o-movimentoautonomo-nao-so-do-brasil-como-do-mundo/

${ }^{62}$ http://coletivodar.org/2013/06/carta-aberta-do-dar-ao-mpl-temos-orgulho-de-dividir-as-ruas-com-voces/
} 
A fase globalizada e neoliberal do capitalismo está no auge. A queda do muro de Berlin simbolizou o fim da polaridade ideológica e o triunfo da hegemonia do capital, entretanto, formas de resistência autônomas ganharam força com o movimento zapatista, no México, a Ação Global dos Povos e os movimentos de ocupação em 2011. Aliada da reestruturação produtiva do capitalismo que fragmentou e precarizou ainda mais a classe trabalhadora, a informatização da sociedade permitiu a criação de novas ferramentas de comunicação empregadas por esses movimentos contra-hegemônicos. Durante as jornadas de junho em São Paulo, vimos que os meios de comunicação digitais serviram para elaborar uma narrativa dos protestos independente da mídia hegemônica e fortalecer a articulação de ativistas autônomos em torno da crítica ao capitalismo e do direito à cidade.

Muitos dos princípios do anarquismo e do autonomismo têm sido amplificados por esses novos sujeitos políticos. A busca por uma luta coletiva e ativa - sem instituições mediadoras-, o combate ao autoritarismo estatal personificado na ação policial, a horizontalidade e o reconhecimento no povo da potência transformadora são constantemente evidenciados nos discursos dos ativistas. No entanto, a criação de novas relações esbarra em limitações materiais impostas pelo capitalismo. A apropriação dos meios de produção, como os veículos de comunicação, é um desafio necessário para avançar na luta pela transformação da sociedade.

\subsection{Passos para uma rede autônoma}

A necessidade de comunicação entre os movimentos que saíram pós-junho motivou a criação do coletivo Mídia Negra, nome que alude à cor da bandeira do anarquismo. Com um website e páginas em redes sociais como Facebook e Vimeo, o coletivo reivindica uma "mídia sem catracas" e propõe divulgar, através da produção audiovisual, "um panorama de lutas e denúncias contra o Estado brasileiro". A crítica à grande mídia, "que torce e distorce qualquer informação para proteger seus próprios interesses econômicos e políticos", é recorrente no discurso do coletivo. Mesmo ciente da posição vantajosa da mídia corporativa, que por visar o lucro possui muito mais recursos do que os veículos independentes, o coletivo enfatiza - em texto de apresentação publicado no Facebook $^{63}$ no dia 27 de setembro de 2013- que não é possível depender apenas das empresas de comunicação para se obter informações, por

${ }^{63}$ A página do Mídia Negra no Facebook tem 4051 curtidas (dado atualizado no dia 1 de julho de 2013) 
isso é necessário buscá-las nas ruas e disseminá-las de "forma participativa, autônoma e comprometida com as lutas".

Vinícius, 24 anos, é um dos cinco colaboradores do Mídia Negra. Quando deu entrevista para esta pesquisa, em novembro de 2013, era o único a atuar de maneira fixa no coletivo. Atuante também do Movimento Passe Livre (MPL) e próximo de movimentos por moradia, ele explica que a autonomia do coletivo se dá no plano financeiro e político. Segundo o ativista, a independência em relação a empresas e partidos torna essenciais as formas de contribuição solidárias. A inscrição do coletivo no Vakinha, site de financiamento coletivo de projetos, foi uma das maneiras encontradas para cobrir parte do que foi gasto com o início da produção do documentário "Baderna" e comprar equipamentos para filmagem - como cartões de memória e baterias para filmadora - e cobertura em áreas de risco - capacetes, máscaras e coletes.

A realização de encontros também é um meio de arrecadar verba para o coletivo. Vinícius comenta que as redes sociais são utilizadas para divulgar eventos inspirados em festas punks, que criam um cenário a partir da união de diferentes elementos.

\footnotetext{
Eu falo isso porque sou da cultura punk, da prática de fazer eventos com vídeos, discussão política, troca de conhecimento, permeando contracultura e subversão. São pessoas que respiram contestação no sentido de contestação cotidiana do Estado, de negação da autoridade, de busca por autoconhecimento. (Vinícius, entrevista, São Paulo, novembro de 2013)
}

A festa "Corações Negros" foi divulgada na página do Facebook a fim de convocar "todos que lutam por um mundo onde caibam todos os mundos", relembrando o lema zapatista. Em parceria com o Centro de Mídia Independente de São Paulo (CMI-SP), a ideia era criar um espaço informal para a troca de informações, o encontro de afinidades e a construção de laços de lutas. A iminência de grandes eventos como a Copa do Mundo, segundo o texto de divulgação da festa, reforça a necessidade de aproximar lutas iguais ou próximas. A valorização das alianças físicas entre militantes antes das alianças entre movimentos reforça a busca por um espaço onde ocorram as articulações. "Corações Negros" aconteceu no dia 5 de outubro de 2013, um sábado, num apartamento alugado onde moram alguns ativistas autônomos, no centro da cidade. Na porta, uma placa com o nome "Emma Goldman", filósofa anarquista russa. O encontro, 
divulgado também por um vídeo postado no Vimeo, teve exibição de curtas e filmes políticos.

No mês seguinte, outro evento no Facebook convidou os militantes para a "Festa por uma Mídia Negra", marcada para o dia 8 de novembro, no espaço autônomo Casa Mafalda, na zona oeste de São Paulo. O objetivo não era arrecadar fundos apenas para as ações do Mídia Negra, mas também para direcionar doações ao Moinho Vivo, movimento de moradores que defendem a manutenção e regularização da Favela no Moinho, que se autointitula a última favela do centro da capital. De acordo com a apresentação do evento, a parceria pretendeu fomentar o uso de ferramentas digitais na favela por meio de programas com software livre, "proporcionando um maior conhecimento em segurança digital, internet, edição e produção de conteúdo”. Com o emprego de diferentes formas de divulgação do cotidiano do movimento, a comunidade teria mais condições de ser ouvida. Entre os itens solicitados, estão peças de computador, cabos de rede, caixas de som, roteador e equipamentos para filmagem. Vinícius comenta o saldo do evento:

\footnotetext{
“Até agora a gente já arrecadou alguns computadores. Em menos de um mês obtivemos resultados. Ainda precisamos consertar alguns computadores e deixá-los adequados com software livre. É importante ter um espaço com computador com acesso à internet pra registrar a chegada da polícia na favela, sem precisar depender de um coletivo ou mídia" (Vinícius, entrevista, São Paulo, novembro de 2013).
}

O texto de divulgação tanto do "Corações Negros" quanto da "Festa por uma Mídia Negra" é encerrado com a reivindicação "Liberdade imediata a todxs xs presxs políticxs!", em referência aos militantes presos durante as jornadas de junho, e a letra "A" entre parênteses, imitando o símbolo do anarquismo. Este último recurso costuma ser a assinatura de todos os textos publicados pelo Mídia Negra. Vinícius confirma o caráter anarquista do coletivo e explica que a autonomia política decorre de um acúmulo de experiências de militantes que não se identificam com as práticas, ideias e processos de partidos e sindicatos. Ele vê o coletivo como um catalisador de informações e observa que a comunicação por mídias digitais é uma das maneiras de manter viva a cultura underground. Os canais de comunicação do coletivo são guiados pelo anticapitalismo, que "resume várias frentes de combate contra o racismo, o fascismo e toda forma de autoridade". O ativista cita o compartilhamento de informação como uma potencialidade da Internet, mas observa que o espaço físico é mais importante. 


\begin{abstract}
"Quando você faz o vídeo de uma pessoa sendo presa, é interessante utilizar a rede social pra poder divulgar e ampliar o conhecimento de que está havendo repressão no local X; alguém que está em outro lugar pode colaborar pra que isso não aconteça. (...) O Mídia Negra usa o espaço da Internet, mas a atuação real mesmo está nas ruas. A internet é uma forma de comunicação pra longe. Através do Mídia Negra, as pessoas que colaboram com o coletivo conseguem expor situações e lutas pra muito longe”. (Vinícius, entrevista, São Paulo, novembro de 2013)
\end{abstract}

O registro dos protestos nas ruas em junho de 2013 levou à idealização do documentário "Baderna". A ideia, de acordo com Vinícius, é mostrar que, ao contrário do que supõe o bordão "O gigante acordou", muitos movimentos nunca deixaram de se mobilizar. Por falta de recursos, o documentário ainda não foi finalizado, mas uma prévia dele está disponível no site de vídeos Vimeo e foi exibida no Cine Ocupa, no Espaço Tortura Nunca Mais, onde militantes do Ocupa Sampa realizavam sessões de filmes seguidas de debate. Com imagens e entrevistas gravadas durante manifestações no Rio de Janeiro e em Belo Horizonte, o coletivo pretende articular uma rede aberta de imagens e histórias de resistência.

A transmissão ao vivo de ações de movimentos sociais tem sido um recurso usado com frequência pelo Mídia Negra e por vários outros ativistas individuais ou membros de coletivos. Através do canal \#Postv, que oferece gratuitamente o serviço de tweetcasting, é possível transmitir eventos a partir de um smartphone, telefone móvel que acessa a Internet. Essa ferramenta permitiu ao Mídia Negra o registro em tempo real de ações como o protesto organizado pelo MPL no dia 14 de agosto que denunciou o desvio de 570 milhões de reais nos contratos das licitações do Metrô e da Companhia Paulista de Trens Metropolitanos (CPTM). A CryptoRave - evento que promoveu em abril na capital paulista atividades sobre segurança, criptografia, hacking, anonimato, privacidade e liberdade na rede - também foi transmitida pelo coletivo.

Vinícius afirma que as parcerias com outros coletivos baseiam-se na luta, definida por ele como uma caminhada política que busca combater o capitalismo. A parceria com o CMI, coletivo que na opinião do ativista representa uma escola para os movimentos libertários recentes, resultou na produção de um vídeo que critica a realização da Expo Mundial, uma feira que em 2020 reuniria em São Paulo empresas, ONGs e governantes para discutir negócios, tecnologia e economia, entre outros assuntos. Segundo o texto exibido no vídeo, o modelo do megaevento se assemelharia ao da Copa do Mundo e Olimpíadas, ou seja, um projeto socialmente excludente e favorável à especulação 
imobiliária e ao enriquecimento de empreiteiras e investidores privados. Outro fruto do encontro do Mídia Negra com CMI foi um vídeo chamado "Chega de genocídio: demarcação das terras já”, referindo-se às terras indígenas.

Na página do coletivo do Vimeo também pode ser visto um vídeo que faz uma prévia do curta "Loucura sim, mas tem seu método", produzido em conjunto com o coletivo Ação Imediata Anarquista (AIA). A produção reúne entrevistas com ativistas de coletivos autogestionários e mostra a luta antimanicomial no Rio de Janeiro. Em sua página do Facebook, o AIA tornou público o apreço pelo Mídia Negra, dizendo que o coletivo formado por anarquistas busca uma mídia sem catracas: "longe das produções e redações burguesas, o Mídia Negra está nas ruas”, pontua.

É importante considerar as parcerias fortalecidas nas redes sociais. O compartilhamento de informações no Facebook possibilita que coletivos divulguem assuntos que lhes são caros e teçam uma corrente temática com críticas ao status quo. O Mídia Negra é um elemento da cadeia de grupos autônomos que se comunicam on line, sendo capaz de divulgar o maior número possível de lutas anticapitalistas. Além dos coletivos citados até aqui, o Mídia Negra expõe contatos públicos com movimentos por moradia como a Ocupação Esperança, comunidade de mais de 700 famílias sem moradia em Osasco, onde o coletivo realizou a exibição de filmes e vídeos da própria ocupação e de outras. No dia 15 de abril deste ano, a página do Mídia Negra no Facebook compartilhou um postagem do Comitê Popular da Copa em que é declarado o apoio aos moradores que realizavam um ato simbólico na porta da prefeitura de Osasco, exigindo um encontro de negociação com o prefeito a fim de evitar a reintegração de posse do terreno.

No mesmo mês, um ativista do coletivo foi para o Rio de Janeiro acompanhar a situação de cinco mil moradores expulsos de um prédio abandonado pela Telerj, atual empresa de telefonia Oi. Por meio de rede social, o coletivo prestou solidariedade às famílias despejadas durante uma operação policial, autorizada pela Justiça, e pediu que os ativistas paulistas endossassem a luta. Uma publicação na página do Facebook denunciou a violência com a qual a polícia retirou os moradores do local e disponibilizou o link do site do coletivo que apresentava um relato acompanhado de imagens sobre a remoção. Foram divulgadas uma lista de necessidades básicas das famílias e uma ação de arrecadamento de doações. O coletivo informou a intenção de pressionar o poder público a providenciar moradia definitiva para todos os desalojados. 
“É um grito de repúdio ao sistema político vigente no país, que para alimentar a especulação imobiliária, a serviço do capital, pratica atrocidades com a população preta, pobre e periférica", diz o texto do coletivo, que conclui: "Nós não queremos Copa, queremos casa!”.

Com o intuito de facilitar a comunicação entre as lutas espalhadas pelo país, o Mídia Negra pediu, por meio do Facebook, que militantes das regiões Norte e Nordeste lhe enviassem informações e relatos escritos, em áudio ou vídeo sobre as manifestações locais. O objetivo era divulgar os conteúdos nos canais virtuais do coletivo e direcionar relatos que contenham violação de direitos humanos ao Menos Letais, grupo autônomo que reivindica a regulamentação do uso de armamentos de baixa letalidade pela polícia, e ao grupo Tortura Nunca Mais, que denuncia a repressão.

\subsection{1- Articulações}

A análise da aproximação do coletivo Mídia Negra com outros coletivos autônomos que também usam as redes digitais evidencia a tentativa de construir uma rede de comunicação contra-hegemônica. A participação do Mídia Negra em transmissões da Rádio Cordel Libertário, sediada em Salvador, é uma das maneiras de fortalecer a produção de informação autônoma. Em seu blog, que disponibiliza o áudio dos programas em tempo real, e redes sociais, a rádio se define como um meio de comunicação libertário, anarquista e autogestionário. Através de sua página no Facebook, convidou ativistas de todo o Brasil a atuar como correspondentes da rádio na cobertura das manifestações e atividades de cunho anarquista em 2014. "Não fiquemos reféns dos meios de comunicação burgueses e nem da esquerda autoritária”, diz o texto da publicação. Com um celular conectado ao computador, a rádio consegue transmitir através do seu blog áudios de ativistas diretamente das ruas.

Em abril deste ano, foi divulgada uma edição do podcast - arquivo de áudio digital "Frequência Damata", do coletivo Desobediência Sonora, na qual Vinícius foi entrevistado para falar sobre o Mídia Negra. Segundo Fernando ${ }^{64}$, que no podcast entrevista ativistas de movimentos sociais e músicos de bandas independentes, o Desobediência Sonora é formado por cinco integrantes e propõe uma atuação "autogestionada e horizontal com uma visão de esquerda". Ele contou que sua

\footnotetext{
${ }^{64}$ Fernando e Murai concederam entrevista para esta pesquisa em janeiro de 2014, na Casa Mafalda, em São Paulo.
} 
experiência política se deu no meio anarcopunk, enquanto que Murai considera-se motivado pela cultura do "faça você mesmo". Murai é publicitário e entrou no Frequência Damata em agosto de 2013, seis anos depois da primeira edição do podcast. Foi ele quem ofereceu o aparato técnico para a reestruturação do programa, que havia sido interrompido por conta de uma ruptura com o dono do estúdio onde era gravado. $\mathrm{O}$ podcast, com duração de 45 minutos, é realizado hoje na Casa Mafalda e sua nova fase inspirou a formação do Desobediência Sonora. No espaço autônomo, o coletivo também promove festivais mensais com a participação de movimentos sociais e bandas e uma discussão política sem rigor acadêmico.

Os arquivos de áudio do Frequência Damata são publicados no site, inaugurado em janeiro de 2014, e nas redes sociais do coletivo, assim como textos sobre ações políticas, resenhas musicais e agenda de shows da cena underground. Fernando, formado em História e atuante em projetos sociais com jovens da periferia, afirma que o coletivo levanta a bandeira da mídia alternativa, pois divulga aquilo que a grande mídia omite. Murai observa que esse projeto não existiria sem a Internet, e Fernando ressalta a dificuldade de se implantar uma emissora de rádio no Brasil. As ferramentas digitais são usadas tanto para divulgar as atividades do coletivo de várias formas quanto para facilitar a comunicação entre seus membros. Murai acrescenta que a internet permite o armazenamento de informações e a construção de um repertório de entrevistas.

A possibilidade de compartilhamento que as redes trazem proporciona a disseminação de conteúdos que contribuem para o debate sobre a conjuntura das movimentações sociais, interligando arte e política. De acordo com Murai, a capacidade de dar voz a pessoas que foram caladas pelos veículos de comunicação tradicionais incide no desenvolvimento de uma narrativa histórica dos coletivos e bandas independentes em São Paulo. Esse trabalho de contar a trajetória dos artistas e ativistas do cenário autônomo, segundo ele, tem sido feito por poucas pessoas e de uma forma frágil nas últimas duas décadas. "Acredito que a gente vem preencher essa lacuna no sentido de que os próprios agentes contem a sua história, servindo como documento que pode ser utilizado como fonte", assinala.

As ferramentas de comunicação digital também possibilitaram a capacidade de autonoticiamento da Favela do Moinho. O movimento Moinho Vivo criado na favela 
não luta apenas pelo direito à moradia, mas por outra lógica social. Flávia ${ }^{65}$, artista plástica que milita no movimento, ressalta o projeto de especulação imobiliária que encarece o metro quadrado da região central da cidade e intensifica a disputa pelo terreno onde residem os moradores. Ao longo do processo judicial que envolve a prefeitura e uma empresa privada, a favela já sofreu incêndios considerados suspeitos pelos moradores e enfrenta problemas como a falta de saneamento básico. O sentimento de abandono alimenta o caráter autônomo do movimento, que se expressa na forma de comunicação. Caio, que participou do Ocupa Sampa e mora na favela desde novembro de 2013, conta que o registro de tudo o que acontece na favela é uma "arma de contrainformação tanto pra dentro quanto pra fora". Ações da favela, visitas policiais e reuniões com a prefeitura são registradas por texto e/ou vídeo e divulgadas pelo Facebook. Um dos objetivos dessa estratégia comunicativa, explica Flávia, é o enfraquecimento das "relações de poder que a prefeitura estabelece ao tentar fazer negociações com poucos moradores a portas fechadas".

A identificação da noção de autonomia comunicativa no fazer dos coletivos remete a um artigo compartilhado pela página do Mídia Negra no Facebook originalmente publicado no Protopia Wiki, um site internacional de compilação de referências libertárias. O artigo intitulado "Mídia Independente" é introduzido com a afirmação de que a capacidade de fazer a própria mídia não depende de universidades e escolas de especialização caras. Os jornalistas anticorporativos devem incentivar que outras pessoas também tenham independência midiática. Ao tomar o IndyMedia como referência, o texto defende o uso da publicação aberta e o trabalho de mídia em rede internacional.

O texto também dá instruções de como usar ferramentas de comunicação e sustenta a publicação de notícias que mostrem "em que lado da barricada se está" - parafraseando o militante do Mídia Negra em entrevista a esta pesquisa. O artigo ainda valoriza a cobertura de ações diretas e se posiciona em uma guerra de informação. Aos interessados em construir uma mídia independente é sugerida a busca pela produção de um material com perspectiva revolucionária e por conexões com outros coletivos. $\mathrm{O}$ alerta do risco de cooptação por interesses liberais e hierarquias internas é seguido do

\footnotetext{
${ }^{65}$ Flávio e Caio, ativistas do movimento Moinho Vivo, concederam entrevista em dezembro de 2013, na Casa Pública, espaço de reunião construído na favela, no centro de São Paulo, pelos próprios moradores.
} 
apelo ao consenso e à democracia direta. Assim, a independência da mídia corporativa se efetivaria.

\subsection{2- Apropriação das ferramentas digitais}

Embora os ativistas reconheçam que as redes digitais contribuem para a independência comunicativa dos coletivos, muitos demonstram uma visão crítica acerca das limitações que o uso de ferramentas privadas traz. Ao mesmo tempo em que disseminam informações anticapitalistas em meios detidos por empresas, coletivos tomam medidas para garantir a segurança de seus conteúdos, tentando afastá-los da vigilância e da censura por parte de corporações e governos. Ciente da espionagem de ativistas nas redes sociais, Elisa comenta que o Centro de Mídia Independente procura fugir dessas ferramentas corporativas. "O CMI continua mantendo toda a responsabilidade de segurança do site. As publicações são anônimas, as ferramentas são livres, as listas de email e chats são seguros", afirma. Ela entende que o anonimato pode proteger o coletivo, mas observa que tem sido cada vez mais difícil manter uma plataforma de publicação aberta anônima.

Em fevereiro de 2014, uma oficina de segurança na Internet para ativistas autônomos buscou dar conselhos sobre como se proteger da vigilância que vem sendo intensificada com os protestos contra a Copa do Mundo. Entretanto, os ministrantes da oficina deixaram claro que a implementação de protocolos de segurança não deve inibir a ação, mas permitir que alguns cuidados sejam tomados. Assuntos estratégicos dos coletivos devem ser discutidos em canais de comunicação seguros de maneira descentralizada para que as informações não se concentrem em uma única pessoa. Entre as precauções, são citados os sistemas de criptografia, que codificam mensagens que só podem ser decifradas com uma chave secreta, desenvolvidos por comunidades de software livre. A cartilha "Criptografia funciona", indicada durante a oficina, recomenda o uso do Linux, sistema operacional composto inteiramente por software livre e código aberto, o que permite ao usuário liberdade e controle total sobre os dados processados no computador.

A cartilha mencionada pode ser acessada no site do grupo Saravá, cujos voluntários pesquisam e provêm instrumentos tecnológicos para movimentos sociais autônomos. Mediante um criterioso processo de hospedagem, o servidor do Saravá acolhe projetos através de plataformas como o Milharal. O Savará ressalta que não pretende ser um mero prestador de serviços, mas um facilitador de uma vizinhança, um ambiente no qual 
os coletivos construam espaços públicos, sem mediações empresariais ou estatais. $\mathrm{O}$ Moinho Vivo, o Rizoma Tendência Libertária e a Baderna Midiática são alguns dos coletivos que têm sites hospedados no Milharal. André, militante da Baderna Midiática - coletivo formado após os protestos de junho para disputar na Internet o significado das manifestações -, conta que a hospedagem na plataforma autônoma foi decidida depois de conversas com pessoas do CMI.

\footnotetext{
"Com o contato com militantes mais experientes, a gente percebeu que era necessário ter o conteúdo em um espaço que não o Facebook e Youtube por conta do controle da informação. Tudo o que a gente publica no Facebook de conteúdo próprio vai também para o blog". (André, entrevista, São Paulo, janeiro de 2014).
}

No final de abril, vários ativistas usaram o Facebook para se manifestar contra a apreensão de discos rígidos dos servidores do Saravá realizada pelo Ministério Público Federal. A fim de identificar usuários dos sistemas do coletivo supondo conduta ilícita, de acordo com nota emitida pelo próprio coletivo, o órgão público enviou um representante para retirar os discos rígidos do principal servidor do Grupo Saravá, localizado no Instituto de Filosofia e Ciências Humanas da Unicamp, deixando fora do ar vários serviços hospedados pelo grupo. O coletivo relatou que novos discos foram instalados e os sistemas e serviços foram restaurados. Segundo o texto compartilhado na rede social, o grupo usa criptografia para proteger os dados em seus servidores e não registra as informações de acesso (IP) de conexão. Logo, identidades e conteúdos não correm o risco de serem violados. Em sua página pessoal no Facebook, o professor Pablo Ortellado mencionou como combustíveis da ação do MPF o artigo 15 do marco civil da Internet, que estabelece a retenção de dados, e "o documento vazio aprovado na \#NetMundial, que não cita vigilância massiva, neutralidade de rede e cyber-guerra".

O Rise Up, provedor de emails autônomo usado pela maioria dos ativistas entrevistados, também se posicionou e afirmou que a apreensão de dados do Saravá expressa um ataque aos direitos de privacidade, integridade de informações pessoais e liberdade de expressão. Assim como o Savará, o Rise Up usa criptografia e não registra o IP dos usuários. Com sede em Seattle e membros no mundo todo, o propósito do coletivo é apoiar a criação de uma sociedade livre, fornecendo comunicação e recursos computacionais para pessoas e grupos comprometidos em lutas contra o capitalismo e outras formas de opressão. Empregando tecnologias de segurança, o Rise Up também mantém a página do grupo de colaboradores da rede mundial de ativistas libertários. 


\section{4-Considerações finais}

Esta dissertação propôs analisar a apropriação dos meios de comunicação digitais por coletivos autônomos atuantes em São Paulo a partir da identificação das potencialidades e limitações em torno do uso das novas mídias. As mutações sofridas pela esfera pública segundo Bucci (2009) e Marcondes Filho (2008) foram relacionadas com as asserções de Lévy $(1999 ;$ 2010) sobre a construção da ciberdemocracia. A internet possibilitou a diversificação de fontes de informação e acelerou o compartilhamento colaborativo de memórias, além de eliminar a distinção entre emissores e receptores. O paradigma da comunicação foi redefinido para abarcar a complexidade dos fluxos comunicacionais, que convivem e interagem com os modelos de comunicação massivos.

As lutas simbólicas intensificadas com a popularização dos ambientes digitais atestam as contradições inerentes à estrutura capitalista, determinadas historicamente por condições econômicas, sociais e políticas. A integração da Internet à ordem capitalista foi inicialmente comentada por Rüdiger (2011), que analisou as mídias digitais por meio da crítica à economia da comunicação. Após considerar a Internet situada em um processo histórico marcado por uma lógica econômica e social, o autor observou a formação de um novo campo de ação histórica que reproduz os antagonismos sociais.

O entendimento da Internet como uma extensão da Indústria Cultural também foi considerado nesta pesquisa. O advento das novas tecnologias de comunicação e informação combinou-se com a consolidação do capitalismo monopolista, caracterizado pela formação de blocos concentrados de capital, reforçando o duplo papel da informação: a acumulação do capital e a reprodução ideológica do sistema (BOLAÑO, 2000). A abordagem da assimilação das tecnologias digitais pela ordem hegemônica teve a contribuição do conceito de príncipe eletrônico formulado por Ianni (2000). A hegemonia globalizada amparada no conhecimento tecnocientífico sustenta a reprodução do capitalismo na base e na superestrutura. Procurou-se deixar claro que a estrutura de poder dominante é constantemente desafiada por diversas formas de resistência.

O trabalho expôs diferentes interpretações sobre o ativismo articulado em redes digitais. A ação direta, sem mediações, que define a mídia tática foi apresentada como um aspecto marcante do uso da comunicação para fins de militância política. A suspeita de que a ação coletiva via web mantém vínculos fracos foi contraposta à constatação do 
entrecruzamento de novos e velhos movimentos sociais interagindo em espaços físicos e virtuais que diversificam as reivindicações e confirmam a perda da exclusividade da pauta classista. Detectou-se a emergência do ciberativismo, um novo protagonismo que emerge da descentralização das redes (DI FELICE, 2008). A negação da hipótese de que a arquitetura informativa molda as mobilizações fez-se necessária para que o ciberativismo não fosse neutralizado junto com a técnica. $\mathrm{O}$ resgate das bases teóricas da mídia radical, levantadas por Downing (2004), cumpriu a função de estabelecer o potencial contra-hegemônico do uso das mídias. A forma horizontal de oposição, baseada na política pré-figurativa da autogestão, recebeu destaque, assim como a noção de audiência ativa, resultado da apropriação crítica da cultura de massas. A ênfase nas múltiplas realidades de opressão e a reconstrução da história e da memória coletivas são papéis desempenhados pela mídia radical.

A leitura da tese de Negri e das críticas a ela endereçadas chegou à conclusão de que a crescente apropriação do trabalho imaterial pelo capitalismo não significa efetivamente um quadro pré-revolucionário. Bernardo notou a participação de trabalhadores imateriais na classe dos gestores, que joga ao lado da burguesia. A informatização caminha ao lado da precarização do que Antunes (1999) chamou de classe que vive do trabalho, que abarca trabalhadores industriais, de serviços e informais, todos interligados na dinâmica de valorização do capital. Porém, percebe-se que novas formas de dominação geram novas formas de resistência, portanto as lutas sociais que surgem no mundo contemporâneo carregam os elementos do atual fase do capitalismo e apresentam características peculiares. O material empírico colhido nas entrevistas evidencia alguns militantes como trabalhadores precarizados. Futuros estudos deverão dar conta de uma análise mais densa do ativismo dentro das relações de trabalho.

Depois de compreender as mudanças estruturais do capitalismo, foi possível traçar uma narrativa de experiências autônomas que têm surgido desde a virada para este século com particular enfoque no uso de meios de comunicação digitais. Situadas no contexto global do neoliberalismo, a trajetória do zapatismo, da Ação Global dos Povos (AGP) e das ocupações em 2011 mostrou que a construção da horizontalidade e da autonomia e a valorização de ações diretas nortearam o emprego das ferramentas midiáticas, tecendo redes de comunicação antissistêmica. 
Nesses termos, o Centro de Mídia Independente (CMI) foi a herança mais expressiva dessas mobilizações. O site de publicação aberta com software livre criado em 1999 para dar cobertura às ações relacionadas ao movimento antiglobalização despertaram o interesse de ativistas por todo o mundo e, embora tenha recuado nos últimos anos, ainda serve de referência e presta solidariedade a coletivos anticapitalistas. Um traço sobressalente da atuação política autônoma consolidada pelo CMI foi a maneira comprometida e parcial do registro dos fatos. A participação em outros movimentos além do CMI indica a postura do produtor de informação enquanto sujeito da ação preocupado em dar visibilidade à reivindicação com a qual compartilha. O coletivo esteve à frente da criação de dispositivos colaborativos, mas com o passar do tempo foi ultrapassado por outros grupos técnicos e enfraquecido pelas dificuldades financeiras e pela vigilância constante.

A autonomia comunicativa desses movimentos foi reencontrada durante os protestos de junho de 2013, em São Paulo. Acompanhou-se o percurso feito pelo Movimento Passe Livre (MPL) a partir de suas publicações no Facebook. O coletivo autônomo que denuncia a exclusão urbana e reivindica o transporte gratuito mostrou ter domínio de seus meios de comunicação para tornar pública sua campanha pela revogação do aumento da passagem. Os ativistas utilizaram a página do movimento na rede social com o objetivo de mostrar a articulação com escolas públicas, periferias e espaços autônomos. O diálogo com o poder público foi estabelecido com a publicação de notas nas quais o MPL ratificava suas demandas. A interação com os veículos de mídia tradicionais e independentes constituiu uma retroalimentação ora harmoniosa ora conturbada, fazendo transparecer a disputa simbólica que movia os debates. A grande mídia - especialmente os jornais Folha e Estadão e a TV Globo - aproveitou a expansão dos protestos e a dispersão da pauta para abandonar o discurso contrário às manifestações e abraçá-las como um "basta” para a corrupção da política brasileira.

As entrevistas com militantes e o acompanhamento de publicações em páginas de coletivos no Facebook embasaram a descrição da forma de atuação política e de apropriação dos meios de comunicação digitais. A criação da Mídia Negra concretizou a ideia de articular as lutas anticapitalistas a fim de fortalecer a rede horizontal. Observouse a aproximação de movimentos por moradia como a Favela do Moinho e a Ocupação Esperança e de coletivos independentes como o Desobediência Sonora, o Baderna Midiática, a Rádio Cordel Libertário e a Casa Mafalda. A maturidade organizacional 
varia de acordo com o coletivo, mas uma dificuldade comum é a falta de recursos financeiros para desenvolver as atividades sem perder a autonomia. A integridade do anticapitalismo é muito cultuada por esses militantes, pois é uma maneira de defesa contra a assimilação capitalista.

Juntos, esses grupos compartilham informações e alimentam correntes temáticas contra o status quo. Os protestos contra a Copa do Mundo têm sido bastante difundidos pelos ativistas, muitos deles apoiando o Comitê Popular da Copa que organizou um protesto contra os impactos do megaevento no dia 15 de maio e tem programado atividades para reunir movimentos em debates e atos. Recentemente, um ativista do comitê que também é da Casa Mafalda deu entrevista para um programa jornalístico do canal Globo News. O objetivo do comitê não só reivindica os direitos daqueles que foram afetados negativamente pela construção das obras da Copa como denuncia a perseguição que os militantes têm sofrido da polícia. O discurso contra a forma como o torneio foi planejado e executado enfrenta o discurso oficial da mídia empresarial e do poder público que celebra o acontecimento patrocinado por multinacionais e organizado pela Fifa. As divergências ideológicas entre a rede Globo e o governo federal parecem desaparecer diante da acumulação de capital prometida.

O emaranhamento dos coletivos autônomos nesse processo de resistência move o projeto da rede "Protesta", que ainda não se efetivou, mas pretende ser uma identidade virtual dos coletivos autônomos em torno de pautas como o acesso à cidade, a desmilitarização e a democratização da comunicação. Ao mesmo tempo, é dado apoio físico e virtual às manifestações do Movimento dos Trabalhadores Sem Teto (MTST) e à greve dos metroviários liderada pelo sindicato em São Paulo. Esse estreitamento de vínculos com organizações tradicionais pode ser um indício de uma tentativa de integração com setores hierarquizados da esquerda, deixando de lado o sectarismo. A adoção de medidas de segurança digital como a criptografia, o software livre e servidores autônomos vem crescendo, o que demonstra uma tendência ao manuseio crítico das ferramentas. Porém, a disseminação de conteúdo para um público maior ainda depende de sites privados como o Facebook e o Twitter.

A reestruturação do modo de produção capitalista apoiada no conhecimento tecnocientífico e na diversificação das formas de exploração acirra a disputa pelo controle dos meios de informação. Tal disputa evidencia antagonismos que têm provado 
sua visibilidade no plano simbólico e material. Longe das vias institucionais, mas não alheio a elas, trabalhadores e estudantes aliam-se para reivindicar direitos concretos como moradia e transporte - e outra lógica social. Formas de organização coletivas e ativas têm construído relações sociais autônomas e anticapitalistas no espaço urbano, um campo cada vez mais legítimo de lutas contra distintas realidades de opressão que possuem uma única raiz. No entanto, a subsunção da mídia, inclusive e principalmente a digital, à ordem hegemônica põe-se como um problema real para os ativistas.

A leitura da ação dos movimentos autônomos identifica fragilidades presentes em diferentes graus nos coletivos. Quando levada ao extremo, a autonomia afasta os ativistas das instâncias decisórias institucionalizadas. A rejeição a qualquer tipo de mediação resulta na ineficiência das ações concretas. A exclusão de militantes ligados a partidos, como fez o Ocupa Sampa, é uma faca de dois gumes. Se, por um lado, ratifica a autonomia do movimento, por outro, corre o risco de reproduzir o autoritarismo tão combatido. A experiência do MPL mostrou que é possível dialogar com governo e organizações hierarquizadas, em busca de mudanças concretas, e mídia corporativa sem abrir mão de seus princípios. A dimensão discursiva dos protestos andou ao lado da dimensão material, o que permitiu a redução da tarifa. Entretanto, outros movimentos carecem dessa visão estratégica e não enxergam além dos limites da ação tática.

O número reduzido de ativistas e o engajamento em diferentes níveis também prejudicam a eficácia da mídia radical e contribuem para a baixa visibilidade. Assim, a construção de uma esfera pública radical perde força. A falta de articulação com movimentos de esquerda verticalizados é um dos fatores do isolamento. Isso diminui o papel dos movimentos autônomos na disputa simbólica com a mídia empresarial. Porém, a assimetria desse embate também se deve à colonização dos meios de comunicação pelas empresas. A privatização dos espaços virtuais põe em xeque a existência de brechas que potencializem os sujeitos políticos. Por isso, a apropriação subversiva dos meios é uma necessidade que pode ser suprida com o desenvolvimento do conhecimento técnico-científico. O coletivo Saravá indica que o diálogo dos ativistas com o meio acadêmico é um caminho para a construção de tecnologias autônomas. 


\section{5- Referências Bibliográficas}

ADORNO, Theodor; HORKHEIMER, Max. Dialética do Esclarecimento. Rio de Janeiro: Zahar, 1985.

ALTAMIRA, Cesar. Os marxismos do novo século. Rio de Janeiro: Record, 2008.

ALVES, Giovanni. Occupy Wall Street...e depois? In Harvey et al. Occupy: movimentos de protesto que tomaram as ruas. São Paulo: Boitempo, 2012.

ANTUNES, Ricardo. "O novo proletariado é a base dos protestos da juventude". A Nova Democracia, n.129, abril de 2014. Disponível em: http://www.anovademocracia.com.br/no-129/5323-o-novo-proletariado-e-a-base-dosprotestos-da-juventude. Acesso em: 30 abril 2014.

BRAGA, Ruy. Sob a sombra do precariado. Cidades Rebeldes: Passe Livre e as manifestações que tomaram as ruas do Brasil. São Paulo: Boitempo, 2013.

BOLAÑO, Cesar. Indústria Cultural, Informação e Capitalismo. São Paulo: Hucitec/Pólis, 2000.

BOLAÑO, Cesar; CASTAÑEDA, Marcos. A Economia Política da Internet e sua Crise in Comunicação, Informação e Cultura. Salvador: Edufpa, 2004.

CASTELLS, Manuel. Redes de indignação e esperança: movimentos sociais na era da Internet. Rio de Janeiro: Zahar, 2013.

CAVA, Bruno. Produzir direitos, gerar o comunismo: teoria do sujeito em Badiou e Negri. Dissertação (Mestrado em Direito) - Centro de Ciências Sociais, Universidade do Rio de Janeiro. Rio de Janeiro, 2012.

CHAUÍ, Marilena. Cidadania cultural, o direito à cultura. São Paulo: Perseu Abramo, 2006.

As manifestações de junho de 2013 na cidade de São Paulo.

Teoria e Debate, n.113, junho de 2013. Disponível em: http://www.teoriaedebate.org.br/materias/nacional/manifestacoes-de-junho-de-2013-nacidade-de-sao-paulo?page=full. Acesso em: 5 agosto 2013.

DI FELICE, Massimo (org). Do público para as redes: a comunicação digital e as novas formas de participação social. São Caetano do Sul: Difusão, 2008;

Paisagens pós-urbanas: o fim da experiência urbana e as formas comunicativas do habitar. São Paulo: Annablume, 2009. 
DI FELICE, M; TORRES, J.; YANAZE, L. Redes digitais e sustentabilidade: as interações com meio ambiente na era da informação. São Paulo: Annablume, 2012.

DOWNING, D.H John. Mídia Radical- Rebeldia nas Comunicações e Movimentos Sociais. São Paulo: Editora SENAC São Paulo, 2004.

FERREIRA, Maria de Nazareth. Alternativas metodológicas para a produção científica. São Paulo: CELACC/ECA-USP, 2006.

FIGUEIREDO, Guilherme. A Guerra é o Espetáculo: origens e transformações do Exército Zapatista de Libertação Nacional. São Carlos: Rima, Fapesp, 2006.

FREDERICO, Celso. Da periferia ao centro: cultura e política em tempos pósmodernos. Estudos Avançados, São Paulo, n.79, outubro de 2013. Disponível em: <http://www.scielo.br/scielo.php?pid=S0103-40142013000300017\&script=sci_arttext>. Acesso em: 20 out 2013.

GLADWELL, Malcolm. A revolução não será tuitada. Disponível em http://sergyovitro.blogspot.com/2010/12/revolucao-nao-sera-tuitada.html

GOHN, Maria Glória. Movimentos Sociais e Redes de Mobilizações Civis no Brasil Contemporâneo. Petrópolis, RJ: Vozes, 2010

HABERMAS, Jürgen. Mudança estrutural da esfera pública: investigações quanto a uma categoria da sociedade burguesa. Rio de Janeiro: Tempo Brasileiro, 1984.

HARVEY, David. A liberdade da cidade. In: MARICATO et. al. Cidades Rebeldes: Passe Livre e as manifestações que tomaram as ruas do Brasil. São Paulo: Boitempo, 2013.

IANNI, Octavio. Enigmas da modernidade-mundo. Rio de Janeiro: Civilização Brasileira, 2000.

LAZZARATO, Maurizio. NEGRI, Antonio. Trabalho Imaterial: formas de vida e produção de subjetividade. Rio de Janeiro: DP\&A, 2001.

LEMOS, André; LÉVY, Pierre. O futuro da internet: em direção a uma ciberdemocracia planetária. São Paulo: Paulus, 2010.

LEÓN, Oswald et all. Movimentos sociais na rede. Disponível em http://www.alainet.org/active/41050.

LESSA, Sérgio. Trabalho imaterial: Negri, Lazzarato e Hardt. Revista Estudos de Sociologia, Unesp-Araraquara, n.11, 2001.

LÉVY, Pierre. Cibercultura. São Paulo: Editora 34, 1999.

Ciberdemocracia. Lisboa: Instituto Piaget, 2002. 
LIBERATO, Leo. Expressões Contemporâneas de Rebeldia: poder e fazer da juventude autonomista. 2006. f. Tese (Doutorado em Sociologia Política) - Centro de Filosofia e Ciências Humanas, Universidade Federal de Santa Catarina. Florianópolis, 2006.

LUDD, Ned (org). Urgência das Ruas: Black blocks, Reclaim the Streets e os Dias de Ação Global. São Paulo: 2002.

LUHMANN, Niklas. Öffentlich Meinung. In: Langenbucher, W. R. (Ed.). Zur Theorie der politischen Kommunikation. München: Piper Verlag GmbH, 1974. Tradução de M. T. Bastos (obra de circulação restrita).

MARCONDES FILHO, Ciro. Comunicação e ação política no contínuo mediático. Luhmann contra Habermas. E nós contra todos. Revista Galaxia, v. 8, n. 15, 2008. Disponível em htttp://www.revistas.univerciencia.org/index.php/galaxia/article/view/5732/5189.

MARICATO, E. É a questão urbana, estúpido! In: MARICATO et. al. Cidades Rebeldes: Passe Livre e as manifestações que tomaram as ruas do Brasil. São Paulo: Boitempo, 2013.

MARX, Karl. Contribuição à crítica da economia política. Tradução e introdução de Florestan Fernandes. São Paulo: Expressão Popular, 2008.

MOVIMENTO Passe Livre São Paulo. Não começou em Salvador, não vai terminar em São Paulo. In: MARICATO et. al. Cidades Rebeldes: Passe Livre e as manifestações que tomaram as ruas do Brasil. São Paulo: Boitempo, 2013.

NEGRI, Antonio. Cinco lições sobre o império. Rio de Janeiro: DP\&A, 2003.

ORTELLADO, Pablo; RYOKI, André. Estamos Vencendo: resistência global no Brasil. São Paulo: Conrad, 2004.

PIMENTEL, Tiago; AMADEU, Sérgio. Cartografia de espaços híbridos: as manifestações de junho de 2013. Disponível em: < http://interagentes.net/?p=62/>. Acesso em: 15 out. 2013.

POMAR et al. Vinte centavos: a luta contra o aumento. São Paulo: Veneta, 2013.

RUDIGER, Francisco. As teorias da cibercultura: perspectivas, questões e autores. Porto Alegre: Sulina, 2011.

SAFATLE, Vladimir. Amar um ideia. In Harvey et al. Occupy: movimentos de protesto que tomaram as ruas. São Paulo: Boitempo, 2012. 
SANTOS, Carlos. A rebeldia por trás das lentes: o Centro de Mídia Independente no Brasil. Florianópolis: Em Debate, 2013.

WILLIAMS, Raymond. Base e superestrutura na teoria cultural marxista. Revista USP, Brasil, n. 66, agosto, 2005. Disponível em http://www.revistasusp.sibi.usp.br/scielo.php?pid=S0103-

99892005000300025\&script=sci_arttext. Acesso em 18 agosto de 2012. 


\section{ANEXOS \\ ANEXO A: ENTREVISTA COM VINÍCIUS, DO COLETIVO MÍDIA NEGRA}

Data: $28 / 11 / 2013$

Idade: 24 anos

Formação: ensino médio completo

Ocupação: vendedor autônomo de alfajores veganos

\section{1-Conte um pouco da sua experiência política.}

Eu me chamo Vina. Sou colaborador no coletivo Midia Negra. Atualmente também faço parte de outros movimentos como o Movimento Passe Livre, estou próximo do Moinho Vivo e de outros movimentos com relação à ocupação de espaços urbanos. De alguma forma militante da bicicleta e ativista de outras necessidades como a alimentação, coisas básicas com as quais a gente nem se preocupa, mas são fundamentais pra que a gente possa permanecer vivo. Talvez eu esteja próximo de lutas que busquem tentar obter o mínimo necessário pra se viver.

\section{2-Como surgiu o Mídia Negra?}

O Mídia Negra surgiu no meio do ano de 2013, num momento em que, mais do que nunca, sente-se a necessidade de melhor comunicação entre lutas, em âmbito local e global, e coletivos isolados para o resto da sociedade. O coletivo bate em cima da crítica ao capitalismo, da indignação com esse processo de exploração. O Mídia Negra é um coletivo autônomo, no sentido financeiro e político, então não há dependência nem necessidade de recorrer a empresas, ONGs, etc. De forma solidária a gente sempre consegue apoio e ferramentas pra poder executar ações públicas de verdade.

\section{3-Por que o investimento de um partido ou empresa prejudicaria o Mídia Negra?}

Se, por exemplo, a Petrobrás oferecesse uma verba ao Mídia Negra, eu não aceitaria enquanto membro do coletivo. É como aceitar um edital da prefeitura que passa pela mão do Fora do Eixo, do governo. Pra somar, eu posso buscar pessoas com afinidades políticas e interesses próximos aos do Mídia Negra. O Mídia Negra não está vinculado a nenhum grupo ou partido de forma que dependa de tal para existir e contra-atacar o capitalismo. A independência política vem de uma restrição que tem a ver com o acúmulo de experiências das pessoas que construíram o coletivo Mídia Negra que não se identificam com as práticas, idéias e processos de partidos e sindicatos. Eu, como anarquista que sou, creio que os sindicatos no começo do século passado foram muito importantes em muitas mudanças sociais, mas atualmente eu vejo que é um processo vendido.

\section{4-Essa estrutura autônoma torna o coletivo livre?}

Sim. A atuação do coletivo é bem ampla. Você pode sugerir ao Mídia Negra a criação de uma rádio, por exemplo, desde que se adeque aos princípios de horizontalidade, anticapitalismo e autonomia. Grosso modo, o termo anticapitalismo resume várias frentes de combate contra o racismo, o fascismo e toda forma de autoridade. Então você 
tem livre acesso para usar os canais que o Mídia Negra oferece a nível virtual: o site, o Facebook, o Vimeo, o Youtube, o canal de streaming. A gente entende que é o audiovisual é uma ferramenta crucial, basta que a gente saiba usar. Você pode fazer um documentário, uma chamada, um programa, um texto ou uma informação de contracultura, anticapitalista. É assim que sobrevive a cultura underground da metade do século passado pra cá, com muitas formas de contracultura cada vez mais presentes. O objetivo do Mídia Negra é usar a ferramenta do audiovisual para vomitar em cima do capitalismo aquilo que o coletivo enxerga como necessário. A internet acaba sendo crucial por uma questão de compartilhamento de informação. Quando você faz o vídeo de uma pessoa sendo presa, é interessante utilizar a rede social pra poder divulgar e ampliar o conhecimento de que está havendo repressão no local X; alguém que está em outro lugar pode colaborar pra que isso não aconteça. Aqui em São Paulo existe o coletivo Menos Letais, que surgiu da luta e tem a finalidade de acabar com utilização de armamento letal ou o que chamam de menos letal, que cega e mata da mesma forma. $\mathrm{O}$ Mídia Negra usa o espaço da Internet, mas a atuação real mesmo está nas ruas. A internet é uma forma de comunicação pra longe. Através do Mídia Negra, as pessoas que colaboram com o coletivo conseguem expor situações e lutas pra muito longe.

\section{5-Como essa integração comunicativa pode trazer um benefício mais concreto pra luta?}

Eu já tive experiências de divulgar coisas que fizeram as pessoas se depararem com um universo que elas nem conheciam. Eu já soube de coisas que aconteceram em um lugar devido a uma informação que chegou através de um canal alternativo de outro lugar bem longe. Eu acredito que a subversão está dentro da gente, o sentimento mais anárquico que pode existir é a nossa essência. Talvez seja a ideia de que a revolução começa de dentro pra fora. Eu tenho reparado em muitas situações que tem acontecido com o auxílio da internet.

\section{6-Que medidas o Mídia Negra toma para se apropriar criticamente da Internet?}

É interessante que ninguém use Windows, que as pessoas tenham softwares livres e se protejam. Quando se usa um computador seguro pra se comunicar, cria-se uma privacidade. A gente tem tido muitas perseguições por parte do Estado de pessoas que se movem em diversos níveis e formas para combater o capital. O mínimo que a gente tem que fazer é ficar atento porque ninguém gosta da ideia de ser acusado por nada. Eu já fui detido e agredido sem um motivo concreto. Por causa disso eu tenho o movimento do pulso prejudicado. Não tive traumas psicológicos, mas tive traumas físicos. Pra quem se mobiliza, a segurança é necessária. O uso de software livre é importante porque você tem possibilidades que os softwares pagos não oferecem de forma acessível. Eu entendo que um provedor como o riseup é seguro porque de alguma forma está próximo à luta. É um provedor sediado fora do Brasil que te dá a possibilidade de conversar com pessoas de outros lugares. Há fóruns de discussão anticapitalistas. A subversão é necessária. Pra que aconteça, ela precisa se concretizar sem deixar de omitir certas coisas como, por exemplo, o percurso de um protesto.

\section{7-O que você entende por democracia?}

Eu entendo por democracia o que eu vivo. Eu sou de 1988. Em 1988, em teoria, oficialmente a gente estava em um sistema democrático. Desde que eu nasci eu vivo num sistema democrático. E é um sistema injusto. Eu não sei o que é um sistema democrático, de fato. Eu vejo que o capitalismo é construído por classes. Talvez o 
anticapitalismo seja a ausência do Estado, mas não é só isso. O que existe além do Estado que precisa ser mudado? Como seria essa nova lógica? Talvez o anticapitalismo venha com uma crítica mais forte que traga alternativas a esse sistema. Já termos como a democracia direta não me contemplam porque permanece uma sensação de controle, de autoridade, de falta de autonomia. O que eu sinto que o anticapitalismo me contempla mais por ser mais combativo.

\section{8-O Mídia Negra busca contribuir com movimentos que não possuem meios de comunicação próprios?}

O Mídia Negra não tem interesse de ensinar, mas busca propor ações que ajudem alguma comunidade a se comunicar. O Mídia Negra fez uma campanha de arrecadação de computadores e afins para montar uma central de contrainformação dentro da comunidade do Moinho, junto com o movimento Moinho Vivo e a Favela do Comboio. Foi uma ideia de pessoas que militam juntas. A ideia é unificar e tentar entender que os nomes são apenas nomes. O que importa é a coisa prática. Se é o coletivo A, B ou C, não importa. Então a gente tenta ser pragmático e fazer uma ação eficaz. Até agora a gente já arrecadou alguns computadores. Em menos de um mês obtivemos resultados. Ainda precisamos consertar alguns computadores e deixá-los adequados com software livre. É importante ter um espaço com computador com acesso à internet pra registrar a chegada da polícia na favela, sem precisar depender de um coletivo ou mídia.

\section{9-O que diferencia o Mídia Negra do Mídia Ninja?}

O que diferencia o Mídia Negra do Mídia Ninja é que o Mídia Negra está interagindo na luta. E estar na luta não significa ir a uma atividade cultural, é estar no cotidiano das lutas. Eu, particularmente, colaboro com o Mídia Negra registrando o que acontece em locais onde eu milito para que outras pessoas conheçam as lutas. O Mídia Negra é um catalisador de informação. Há pessoas de outras cidades que mandam informações ao Mídia Negra pra divulgar atividades culturais e políticas. O Mídia Negra atua com movimentos sociais, fala de movimentos sociais para a sociedade, fala da sociedade para a sociedade. O Mídia Ninja virou uma rede de várias pessoas que fazem streaming. Fora as transmissões, que são interessantes, você tem o que? Eu, como integrante do MPL, um movimento novo que tem menos de dez anos, observei que o trabalho de base é muito importante. Trabalho de base é construir as coisas cotidianamente. É um processo anárquico.

\section{0-Existem princípios que regem as parcerias com outros coletivos?}

O Mídia Negra com certeza não vai estar próximo de um movimento a favor da homofobia. O Mídia Negra vai rechaçar e denunciar esse grupo. Não podemos ficar calados diante da existência de um movimento desses. Não dá pra não reagir. As parcerias são baseadas na luta.

\section{1-Como é a relação com partidos ou grupos ligados a partidos?}

Não existe muito interesse nessa troca.

\section{2-O que você define como luta?}

A luta é uma energia que você emprega em algo. A luta está próxima de universos que não se cansam de combater o capitalismo. A luta é a caminhada política, é a luta por conquistas. O Mídia Negra é um coletivo muito aberto a mudanças. Cada ação 
divulgada é muito importante. Em São Paulo, a gente tem um cenário com uma rotina politicamente ativa.

13-Você acha que ações que priorizam o processo - como as acampadas do Ocupa Sampa - podem conviver com ações mais concretas como a reivindicação da redução da tarifa de ônibus?

Eu acho que cada ação contra o capital é fundamental. Tanto pular catraca quanto criar um espaço onde se desenvolva outro tipo dinâmica social são ações válidas. Ocupações, no geral, potencializam a contracultura. O Passe Livre tem a característica das pautas únicas e traz um processo de luta política importante porque é horizontal, abaixo e à esquerda.

\section{4-Qual a relação do Mídia Negra com o CMI?}

De proximidade. Porque o CMI é uma escola principalmente pra quem fez parte da vida política libertária em São Paulo entre 2000 e 2010. O Mídia Negra não faz reuniões com o CMI, mas eu sou amigo de pessoas do coletivo e as encontro em várias atividades. $\mathrm{O}$ ativismo compõe a nossa vida. São parceiros, mas cumprem papéis diferentes porque o Mídia Negra é um coletivo que trabalha com audiovisual pra denunciar as merdas que o estado faz, já o CMI tem abertura pra impresso, digital, rádio. Durante muito tempo, o CMI foi referência pra movimentos abaixo e à esquerda. O CMI era o meio de comunicação mais rápido, onde se encontrava mais relatos de lutas. Eu não imagino que o Mídia Negra tenha essa intenção. Não tem o mesmo suporte de site, esse sistema que eles usam pra preservar as informações.

O objetivo do Mídia Negra é criar toda uma esfera em torno do audiovisual de forma que a gente consiga alcançar o máximo de pessoas possível. A questão da Internet é muito presente porque é o meio que mais temos usado. Porém, eu não vou editar um vídeo pra necessariamente publicar na internet. O Mídia Negra não é um coletivo que quer produzir material pra mostrar em festivais, concorrer a edital ou ganhar dinheiro. São pessoas que têm uma vida ativa politicamente e têm a possibilidade de expor várias coisas que presenciam. Não é uma empresa. Por isso é aberto, quem quiser participar tem que ter um interesse genuíno. Aí dá pra criar processos em cima da espontaneidade.

\section{5-O Mídia Negra tem uma ideologia?}

O Mídia Negra é anarquista. Eu não sou muito apegado a teorias, sou mais da prática.

Eu estive muito envolvido com os protestos de junho, foi um período muito intenso. Mas depois parece que morreu, só que não. Agosto e setembro foram meses de luta por habitação, que têm construído processos de luta muito de diferentes do que esse lixo que é a luta por moradia no centro, não necessariamente pelas pessoas que ocupam, mas pela coordenação que é dominada pelo PT.

\section{6-Podemos dizer que o coletivo faz uma cobertura parcial dos fatos?}

Mídia Negra é parcial. É a necessidade da voz do oprimido. Eu e as pessoas que colaboram com o Mídia Negra não conseguimos ser imparciais e esconder o lado da barricada em que estamos. Eu estou do lado que usa estilingue, das pessoas que não gostam da polícia, que gostam da natureza, que gostam de ser livres, que não aceitam ser oprimidas. Eu sobrevivo com uma renda baixíssima, não tenho curso superior. Já trabalhei com muitas coisas, mas eu não sou especializado em nada. Eu tô na merda 
igual a muita gente. Com certeza é um coletivo com uma ideia combativa ao capitalismo, com intenções anárquicas, sempre tentando promover a subversão com conteúdo nosso. No site a gente consegue só publicar material nosso, mas a gente usa o facebook pra divulgar outras situações. Inspirados em festas punks, os eventos promovidos pelo Mídia Negra pra arrecadar fundos pra compra de materiais tentam agregar uma série de universos e elementos e criar um cenário. Eu falo isso porque sou da cultura punk, da prática de fazer eventos com vídeos, discussão política, troca de conhecimento, permeando contracultura e subversão. São pessoas que respiram contestação no sentido de contestação cotidiana do Estado, de negação da autoridade, de busca por autoconhecimento.

O Mídia Negra surge de algo que eu já estava habituado a fazer que é registrar protestos e estar envolvido em lutas. A mescla disso com a necessidade de saber de outras lutas políticas em outros lugares que outras pessoas que estão comigo não sabiam. Só sabe através da rede Globo? Não é assim que funcionou até agora, não é assim que vai funcionar daqui pra frente. A ideia de fazer um documentário agregou outras pessoas, abriu portar e trouxe mais reflexões, criando assim um coletivo com princípios, funções e necessidades. Eu não gravo pra venda, eu gravo pras pessoas poderem ver e ter discernimento pra entender o contexto. Num protesto de rua, eu sou em certa medida imparcial porque eu mostro tudo. Mas se a tropa de choque aparece espancando algum manifestante, isso vai ser mais importante do que qualquer outra coisa. O Mídia Negra não tem tantos vídeos porque, como atua com outros movimentos, acaba atrelado a essa movimentação de rua. Existem vídeos produzidos conjuntamente com o CMI. Quem dá a narrativa é a luta.

\section{7-O coletivo busca fazer uma crítica à grande mídia empresarial?}

Existe um descontentamento com relação à atuação midiática na sociedade. Existe um grupo de rap que eu escuto que critica a máfia da comunicação. Com certeza existe um vácuo de informação, uma intenção muito maléfica com o intuito de doutrinar a população através da mídia. Não dá pra aturar mais isso. Há muito tempo vários grupos vem pautando a crítica à mídia. Há ligação pessoa com membros do coletivo Baderna midiática, mas não há um trabalho em conjunto. Gostaria muito que o Baderna Midiática entrasse com Mídia Negra, CMI e Moinho Vivo na Casa Pública. Devido a essa margem que foi criada, a esse espaço que não é ocupado como deveria, a grande mídia é ausente. Cabe a nós nos organizar e fazer. Com relação a isso, o Mídia Negra bate em cima da mídia e não quer depender das emissoras de televisão e rádio. Existem várias rádios libertárias em frequiências na internet. Não consigo imaginar em alternativas mais concretas de combater a mídia do que ser a própria mídia.

\section{8-Do que trata o documentário Baderna?}

O documentário Baderna tende a trazer uma visão mais insurrecta desse período do meio do ano de 2013 no Brasil, trazendo uma reflexão de que não existe gigante nenhum. Há muitas pessoas que há muito tempo se mobilizam e saem às ruas. Protesto não é novidade. A ideia do documentário é mostrar grupos, movimentos e coletivos que já se movem, que estão ativos politicamente. Em julho, viajamos pra Belo Horizonte, onde ficamos durante uma semana e registra o processo de ocupação da Câmara Municipal por parte da Assembleia Popular horizontal. Depois fomos pro Rio de Janeiro e recolhemos material com professores de universidade e militantes. Falamos com o Pimenta do Cebraspo (Centro de Solidariedade aos Povos), com representante da movimentação da Favela da Maré, com preso político. A prévia do documentário é uma 
amostra bem crua do tipo de material que a gente colheu. Eu sobrevivi por pouco de algumas noites lá. Esse documentário é uma denúncia dessa atrocidade que está acontecendo, que não começou no meio do ano e não vai terminar agora. Escutar um relato de uma situação de desalojo é muito diferente de ver um vídeo mostrando uma situação de desalojo.

\section{9-De que forma você participa da Ocupação Esperança?}

Eu atuo na ocupação Esperança, que é organizada pelo Luta Popular, um movimento ligado ao PSTU. O que o Mídia Negra está fazendo na Ocupação Esperança? O Mídia Negra entende que a Ocupação Esperança tem uma atuação que visa a autonomia do indivíduo. Os coordenadores da ocupação fazem parte de uma corrente dentro do Luta Popular que não curte partido, curte paradas mais libertárias. A Ocupação Esperança começou há pouco tempo, ainda não tem eletricidade. Rola fazer exibição de filme, arrumar um gerador emprestado. Exibimos vídeos da própria ocupação e outras. Quem é de movimentação política se sente motivado quando vê outra luta com a qual você se identifica. 


\section{ANEXO B: ENTREVISTA COM ELISA E PÂMELA DO CENTRO DE MÍDIA INDEPENDENTE SÃO PAULO (CMI-SP)}

Data: 04/02/2014

\section{Entrevistada 1}

Nome e/ou codinome: Elisa

Idade: 31 anos

Formação: cientista política

Ocupação: trabalha

\section{Entrevistada 2}

Nome e/ou codinome: Pâmela

Idade: 23 anos

Formação: estudante de jornalismo

Ocupação: operadora de telemarketing

\section{1-Como se envolveu com o CMI?}

Elisa: Bom, eu comecei a militar no movimento antiglobalização em 2001, tinha um coletivo que tocava nas manifestações organizadas pelo pessoal da AGP em São Paulo. Depois desse coletivo eu entrei no CMI, logo depois dos protestos contra a ALCA, em 2001. A gente fazia parte de uma rede de coletivos que encampavam os protestos em São Paulo e essa rede tinha uma necessidade muito grande de ter um veículo de comunicação próprio porque o que a mídia cobria não era a realidade do que estava acontecendo nas ruas, eles não sabiam nem por que as pessoas estavam protestando. E aí veio essa ideia de ter um Centro de Mídia Independente no Brasil., e começou o CMI em São Paulo, depois o pessoal do Rio aderiu e foi se expandindo.

Pâmela: a minha experiência é bem recente no CMI, comecei no ano passado, 2013. Na verdade eu já fazia umas fotos pro Anonymous, sem vínculo nenhum, mas eu conheci o CMI e entrei. De lá pra cá, eu venho ajudando com fotos de protestos. Vou fazer um ano lá. E tô aí, aprendendo.

\section{2-Que princípios fundamentam CMI?}

Elisa: A rede Indymedia surge como uma plataforma de publicação aberta, a primeira plataforma de publicação aberta do mundo, numa época em que a Internet não era acessível, não era a internet 3.0 que é essa que a gente está vivendo. Mas o boom de Internet que a gente conheceu foi na web 2.0. A rede surgiu na web 1.0 que era muito precária, você tinha uma relação muito passiva com a Internet, você só recebia informações. E aí o site entrou no ar em 1999, chamando as pessoas a publicarem. Começou com uma proposta de jornalistas independentes free-lancers, só que quando as pessoas que estavam no protesto da OMC, no encontro do Milênio, descobriram esse site, elas começaram a publicar os próprios relatos, das pessoas sendo presos, os vídeos, 
as fotos. E isso fez o CMI desbancar a audiência da CNN em 1999. Um super boom de audiência pro site. E ele não tinha uma estruturação, ninguém nunca pensou que ele ia ser o que é hoje. Criou-se uma carta de princípios básicos de autonomia, horizontalidade, transparência pra facilitar que o site fosse incorporado em outros lugares e que ele não fosse apropriado por nenhum grupo político. Então o site tem uma estrutura que não permite apropriação.

\section{3-Por que você se interessou pelo CMI?}

Pâmela: O que me motivou foi justamente essa mídia independente, de você poder publicar aquilo que não está sendo mostrado pela grande mídia, de poder mostrar realmente o que estava acontecendo.

\section{4-Por que o termo antiglobalização incomoda os ativistas?}

Elisa: É porque a luta é tão global quanto o capital. Não era antiglobalização, era anticapitalista. É contra a globalização das corporações, não contra a globalização da luta. O que a gente fez foi uma luta global, as ações da AGP, coordenadas no mundo inteiro ao mesmo tempo, foram globais. Falar antiglobalização parece que você é contra os avanços da globalização. Não é isso, a gente é contra o capitalismo.

\section{5-Em termos de estratégia e ação, no que consiste o anticapitalismo?}

Elisa: O CMI tem uma estrutura totalmente livre de corporações e de qualquer tipo de financiamento. A gente entende que um veículo de comunicação independente não pode ser financiado por corporações nem pelo Estado. A nossa visão anticapitalista é não fortalecer essas empresas, a gente se baseia na utilização do software livre. A gente desenvolve os softwares que a gente usa, os servidores são nossos, as ferramentas são todas criadas por uma estrutura de técnicos que são da própria rede. Se você fizer uma análise do avanço da tecnologia, você vai ver que as pessoas da rede Indymedia foram responsáveis por várias das ferramentas que vocês usam hoje. A gente tem desenvolvedores do Indymedia que criaram o Twitter. São várias pessoas conjuntamente pensando em resolver problemas, como os problemas eram os mesmos a gente fez a tecnologia avançar muito. O primeiro Wiki que existiu não foi o do Wikipedia, foi o Docs do Indymedia.

\section{6-O que torna o CMI radical e diferente da mídia convencional e de mídias alternativas como o Mídia Ninja?}

Elisa: A postura anticapitalista. O Mídia Ninja recebe sim financiamento, embora diga que não, é um braço do Fora do Eixo. O CMI não recebe financiamento nenhum, vive de doações que normalmente partem dos voluntários. A política editorial é totalmente transparente, está no site. A lista editorial era aberta até o Google existir e começar a causar alguns problemas. O CMI não sou eu ou a Pâmela, é todo mundo. Qualquer pessoa pode publicar. Eu não tenho o poder de dominar o site. Fazendo uma comparação, Mídia Ninja é a pessoa que tem o celular, faz a cobertura e usa aquela marca. Qualquer pessoa pode abrir um CMI na sua cidade, se aceitar a carta de princípios. A publicação é totalmente aberta. A moderação é a posteriori, os artigos que são escondidos são só os que ferem a política editorial: artigos racistas, homofóbicos, preconceituosos de qualquer forma, ataques pessoais, propagandas políticas.

\section{7-O que você faz no CMI e como pretende continuar contribuindo?}


Elisa: Eu faço tudo que precisar fazer; eu só não consigo tirar foto porque sempre fica horrível. Faço publicação, cuido da moderação das listas, da administração do site e faço conexão com o Indymeda global.

Pâmela: Eu fico mais nas fotos mesmo. Eu gosto de rua, de estar lá na hora vendo as coisas acontecendo. Eu sentia necessidade de fazer algo com a qual eu pudesse ser mais livre, falar o que eu quero e não o que outra pessoa quer que eu fale. Na faculdade, eu aprendo a controlar as informações, que é normalmente o que a mídia empresarial faz.

Elisa: O posicionamento claro ao lado dos movimentos sociais é outro diferencial do CMI. É um veículo de comunicação dos movimentos sociais, por isso é tendencioso. A gente não está lá pra ser imparcial. No começo do CMI a gente tentava manter a imparcialidade, deixar as opiniões divergentes, mas com o advento da Internet todo mundo abre seu blog e publica a sua opinião. O CMI dá voz às pessoas que não têm. A maior parte das pessoas que são voluntárias do CMI é militante de algum movimento social. Às vezes o CMI fica sem voluntários porque eles vão todos pros movimentos sociais e isso é bom porque acaba sendo uma porta de entrada pra outras lutas. A pessoa vem interessada em fazer a cobertura, se envolve com o movimento e acaba indo pro movimento. Às vezes as pessoas fazem o movimento contrário, o movimento precisa se fortalecer na comunicação e joga as pessoas para o CMI.

\section{8-Como se dá o contato entre os coletivos locais e o coletivo global?}

Elisa: Na prática, a melhor ferramenta que a gente conseguir criar são as listas de email, divididas por tópicos: finance, communication, legal, process, editorial. Tem pessoas no mundo inteiro nessas listas.

\section{9-Quem é responsável pela parte técnica do coletivo?}

Elisa: O CMI tem seu próprio coletivo técnico, que desenvolve e mantém as ferramentas que a gente usa. Mas o que eu vi acontecer nos últimos anos é que o CMI foi ficando pra trás na parte técnica e outros coletivos técnicos começaram a surgir a partir do CMI, um exemplo é o Saravá e o Rise up. Todas as pessoas do Saravá já foram do CMI.

\section{0-O CMI se afastou das lutas nos últimos anos? Por que?}

Sim. Com essas ferramentas de Internet, o CMI perdeu o fôlego. As pessoas que desenvolveram o site foram cuidar da própria vida, o site não teve uma atualização tecnológica, mas se manteve de pé porque os princípios continuam lá e a ferramenta não consegue ser hackeada - o site nunca caiu. Ele tem servido nesses anos todos como arquivo dos movimentos sociais.

\section{1-Como você lida com a escassez de tempo pro ativismo, uma vez que muitos precisam trabalhar?}

Pâmela: Eu trabalho e faço faculdade e no tempo livre ainda tento fazer as coisas do CMI. As pessoas até brincando comigo dizendo "nossa, você trabalha $48 \mathrm{~h}$ por dia". Mas dá pra administrar o tempo livre e é bacana.

Elisa: Não há a estrutura financeira que esses sites de mídia alternativa têm. É muito mais difícil se manter.

Como o princípio da horizontalidade pode ser visto no cotidiano do CMI? 
Elisa: As decisões são tomadas por consenso, são discutidas em reunião presencial ou lista de de e-mail. Qualquer pessoa de fora pode participar. O processo tenta ser o mais transparente possível. Os editorais vão pro site num processo que a gente criou de três oks. Alguém manda uma proposta pra lista de e-mail e quando recebe três aprovações ele sobe.

\section{2-Que identificação o coletivo tem com o zapatismo?}

Elisa: O CMI foi criado a partir de um chamado do subcomandante Marcos dizendo que os movimentos sociais precisavam ter seus meios de comunicação. A gente sempre esteve muito ligado ao movimento zapatista, sempre se inspirou muito no movimento.

Pâmela: Eu conheço pouco os zapatistas.

\section{3-Há limitações em usar a Internet em uma sociedade capitalista?}

Elisa: Eu sou uma das pessoas que acha que não temos que usar ferramentas como o Facebook, mas sou voto vencido porque as pessoas estão no Facebook e no Twitter. Se você quer atingir essas pessoas tem que usar essas ferramentas. Mas o CMI continua mantendo toda a responsabilidade de segurança do site. As publicações são anônimas, as ferramentas são livres, as listas de e-mail e chat são seguras. A gente tenta fugir dessas ferramentas corporativas que só servem pra prejudicar os movimentos. Todas as pessoas estão sendo espionadas, e durante a jornada de junho a gente viu o que aconteceu com as pessoas que usaram o Facebook pra protestar. Muitas foram perseguidas.

Pâmela: A gente busca usar o Facebook e Twitter pra levar as pessoas até o site. Os editorais vão todos para o Facebook, mas pra ler a pessoa precisa acessar o site.

\section{4-Existe uma ligação entre o CMI e o Milharal, plataforma de blogs sociais?}

Elisa: O Milharal é uma fazenda de wordpress instalada no servidor do Saravá criado por um grupo de pessoas do Saravá e do Ocupa Sampa. É uma plataforma hiper segura que hospeda vários sites de movimentos sociais.

\section{5-A Internet determina a forma de atuação política autônoma?}

Pâmela: Acho que se não fosse a Internet poderia ter sido qualquer outro meio. Apesar de que a informação chegue muito mais rápido pela Internet, não foi a ferramenta que me influenciou a fazer política. O que me influencia é o real, o cotidiano.

Elisa: Eu sou totalmente contra essa visão. A gente determinou os passos que a Internet seguir, a gente criou as ferramentas que a gente queria. Eu não sou a única pessoa a dizer isso. Os ativistas determinaram os rumos da Internet. A Internet foi criada pelo Exército, que vive tentando controlá-la, mas os ativistas estão na vanguarda do desenvolvimento tecnológico.

\section{6-Como o coletivo vem se defendendo da repressão?}

Elisa: O anonimato pode proteger o coletivo como vem protegendo ao longo desses anos, mas tem sido cada vez mais difícil manter uma plataforma de publicação aberta anônima. A gente recebe muita denúncia. Com a mudança da legislação da Internet e a não regulamentação do marco civil, daqui a pouco a gente vai ter que fechar o site porque a gente não vai poder mais garantir que as pessoas publiquem sem logar IP. 
17-Apesar dos problemas, houve um amadurecimento político dos militantes do CMI?

Elisa: Eu não sei, porque a rotatividade de pessoas é muito alta. Não dá pra saber.

18-Que problemas da realidade brasileira impulsionam a atuação do CMI?

Elisa: A gente mora no Brasil, onde o quarto poder é a mídia. A justificativa da existência do CMI é o poder que a mídia tem de influenciar as decisões políticas no país. Isso mostra o quanto é necessário ter veículos de comunicação alternativa que mostrem outra versão dos fatos.

Pâmela: Eu moro em favela e vejo muita coisa errada. Polícia batendo em todo mundo. Muita coisa errada que é mostrada de forma diferente, culpando sempre as vítimas.

\section{9-Como é o engajamento político na favela onde você mora?}

Pâmela: No Capão Redondo há poucos coletivos autônomos.

\section{0-Como foi a cobertura dos protestos de junho de 2013?}

Elisa: Ruim.

Pâmela: Naquela época eu tinha acabado de entrar no CMI. Eu cheguei a tirar algumas fotos, mas eu mais participei do que cobri.

Elisa: Eu não consegui cobrir porque o MPL precisava de ajuda pra tocar os atos.

\section{1-Qual a relação do coletivo com o Mídia Negra?}

O Vinícius do Mídia Negra é muito próximo do CMI, a gente sempre está junto nas ruas. Eu não acompanhei muito a formação do Mídia Negra, mas ele surgiu no embalo de produzir vídeos sobre as manifestações.

\section{2-O que o CMI está planejando para a Copa do Mundo?}

Pâmela: Vai ter bastante coisa nesse ano.

Elisa: Material pra cobrir não vai faltar. Seria ótimo aumentar o número de voluntários.

\section{3-O que é a rede Protesta?}

Elisa: A Rede Protesta vai virar Manifestação.org. São vários coletivos juntos que queriam criar uma identidade na Internet. Existem as pautas básicas que são: acesso à cidade, desmilitarização e democratização da comunicação, três pontos que são caros a todos os movimentos autônomos. O objetivo é disseminar o que a gente pensa, nossas publicações.

\section{4-O coletivo prioriza o processo ao resultado?}

Elisa: Os movimentos autônomos dessa nova geração estão muito focados no processo. A gente entende que é no processo que se traz as pessoas para o mundo novo em construção. É no processo que você entende o que é autonomia e o que é preciso pra mudar o mundo. Os nossos meios são os nossos fins. A gente tem que ir construindo o mundo que a gente quer durante os processos. Isso demora muito mais. A jornada de 
junho foi a primeira vez que a gente conseguiu focar em uma pauta pontual e atingi-la de forma rápida, sem dispensar o processo. Os processos são super longos, as reuniões do MPL duram horas, é tudo baseado em consenso. Eles só conseguiram atingir essa meta porque o processo vem sendo feito por vários anos.

\section{5-A dificuldade de financiamento dificulta a autonomia do coletivo?}

Elisa: Acho que não precisa ter dinheiro quando se tem solidariedade, que é a base de uma organização autônoma. Todo mundo se ajuda. O CMI nunca precisou pedir dinheiro pra nada; Não há necessidade de comprometer o caráter da organização para obter financiamento. Às vezes isso pode atrasar o processo, mas vale mais a pena manter a integridade do coletivo.

\section{6-Como você lida com a questão da exploração do trabalho?}

Pâmela: Existem formas de opressão mais fortes do que a exploração do trabalho. Eu acho super válido contestar quando há coisas erradas...não sei o que dizer.

Elisa: Eu era representante do sindicado da Cinemateca Brasileira. O trabalho não está saindo de pauta, o que acontece é que a visão clássica marxista de que o proletário é o grande motor da humanidade, de que ele vai causar a revolução, muda quando chegamos a uma geração em que o trabalho braçal não é o tipo de trabalho mais executado pelas pessoas. $\mathrm{O}$ trabalho imaterial e intelectual é muito maior. O que fazer com esse monte de gente precariada? Como se organiza? A gente vai lutar pelo quê? O capitalismo acabou com a estrutura de trabalho, dificultando a organização dos trabalhadores.

\section{7-O que você acha do governo Luma e Dilma?}

Pâmela: As bolsas podem até ajudar as pessoas, mas não resolvem.

Elisa: Eles conseguiram introduzir o capitalismo no Brasil. O governo possibilitou o acesso aos bens à população que não tinha. A força dos protestos de junho se deve à grande participação da mídia inflamando as pessoas pra saírem às ruas pra protesta contra esse governo corrupto. Maior parte das pessoas nunca tinham botado o pé na rua e protestaram porque estavam indignadas com a corrupção que sempre existiu no país. Hoje a corrupção só é mais visada por conta da grande campanha que a mídia faz contra o Partido dos Trabalhadores

\section{8-A manifestação pacífica pode conviver com a violenta?}

Acho que a manifestação pacífica pode conviver com a violenta, como sempre conviveram. Acho que a violência é institucionalizada. As pessoas são violentas porque vivem a violência no dia a dia, são tratadas dessa forma. A forma como o Estado trata as pessoas piora a violência.

Pâmela: Black Block é uma tática de manifestação anarquista. E o anarquismo prega que para haver uma grande mudança é preciso chamar a atenção. O Black block é anticapitalista e mostram que uma mudança é urgente. Não dá pra haver uma grande mudança sem chamar a atenção.

\section{9-O que você espera em 2014?}


Pâmela: Eu espero que esteja por vir muita mudança. Pretendo participar bastante como ativista. $\mathrm{O}$ que mais me indigna é o machismo.

Elisa: Eu espero que este ano a gente sobreviva, o que vai ser bem difícil porque a repressão anda bem organizada. Estão acontecendo algumas mudanças no Ministério da Defesa comparáveis ao AI-5, e ninguém está prestando atenção nisso. A gente vai ser reprimido nas ruas e na Internet. As pessoas que foram pras ruas não aceitaram nenhum acordo de pacificação com o governo como fizeram os movimentos como o MST e partidos de esquerda quando Lula se elegeu. Essas pessoas são jovens que cresceram na geração Lula e não tinham nenhum envolvimento político com o governo. Estão em processo de formação política. Esse ano a gente vai ver quem vai ficar pra luta, se as pessoas só entraram no embalo dos protestos porque a Globo convocou ou se estão realmente a fim de fazer acontecer.

\section{0-Como você imagina a revolução?}

Elisa: Eu acho que é um processo e não dá pra ser uma tomada de poder. Tem que começar com educação. As pessoas precisam saber o que elas querem e estar preparadas pra uma sociedade livre. O que a gente vê hoje é que elas não estão preparadas, elas não sabem viver sem essa estrutura que delimita as ações. Acho que é um processo longo de mudança de estrutura e a gente não está nem no caminho.

\section{1-Um movimento anticapitalista corre o risco de ser assimilado pelo capitalismo?}

Elisa: Se o movimento se intitula anticapitalista é porque tem um estudo e uma noção do que está fazendo. Acho muito mais fácil que as pessoas novas que se dizem ativistas sejam englobadas pelo capitalismo. Chegar ao anticapitalismo é muito difícil. Os integrantes do Mídia Ninja não são anticapitalistas, são liberais. O CMI passou anos discutindo sobre anticapitalismo. É difícil consensuar entre pessoas diferentes o princípio do anticapitalismo. A influência do CMI, particularmente no Brasil, é muito anarquista. Foi formado por pessoas que eram anarquistas. 


\section{ANEXO C: ENTREVISTA COM O COLETIVO AÇÃO DIRETA ANARQUISTA}

Data: 27/06/14 (a entrevista foi concedida pelo e-mail do coletivo. Informações sobre os membros do grupo não foram concedidas).

1- O coletivo nasce da necessidade de construir uma comunicação libertária. Por que é importante travar essa luta no contexto em que estamos vivendo?

O Estado e o sistema capitalista detém o poder da informação. A democracia representativa é uma ilusão ditatorial encenada diariamente nos canais de comunicação corporativista. As populações são levadas a acreditar que tem direito à escolha, direitos básicos e até mesmo à lazer, quando a realidade nos mostra o oposto. A visão e posicionamento de quem vive na pobreza e está nas ruas nunca são divulgados por essas mídias gordas. Pelo contrário, tudo que é produzido nesses meios tem intenção de direcionamento reacionário e pura alienação, evitando que todxs tenham acesso à verdade e assim evitando também que se rebelem contra o sistema vigente.

Até mesmo a internet, que supostamente é um meio livre de acesso à informação, é direcionada e limitada por publicidade e jornais mentirosos. O próprio facebook seleciona o que você vê e publica. Além disso, os e-mails e redes sociais comuns são todos monitorados pelo Estado. A partir daí, meios de comunicação libertários suprem a necessidade de difusão da realidade e ideologia dxs oprimidxs, de forma sigilosa (o que nos protege da perseguição política) e independente. Não há censura, hierarquia ou seleção de notícias por um grupo específico. São xs próprixs oprimidxs que decidem o que vão pautar, buscam autonomia para produzir os materiais e fazem a divulgação. Naturalmente essas mídias independentes se apoiam mutuamente, criando assim uma espécie de rede. Os Zapatistas já comprovaram a possibilidade de uma sociedade alternativa que faça sua própria comunicação.

\section{2- Quantas pessoas fazem parte do coletivo e como as funções são distribuídas?}

Preferimos não informar quantas pessoas fazem parte do coletivo, por questões de segurança.

Não há funções pré-estabelecidas. Os indivíduos têm claramente mais interesse em algumas atividades que outras. As produções, atividades, projetos são sugeridos e só participa quem tiver interesse. A partir daí estabelecemos o que precisamos para desenvolver o projeto e de forma voluntária, cada integrante decide o que prefere fazer. As funções podem variar muito de acordo com cada atividade. Acreditamos que o ideal é que cada umx possa exercer um papel diferente esporadicamente, para desenvolver várias habilidades, mas nunca de forma obrigatória.

\section{3- Por que a preferência pelo uso das mídias digitais? Que potencialidades a Internet traz?}

Na realidade nosso coletivo tem a intenção de criar um jornal impresso. Nossa escolha pelas mídias digitais não foi preferencial, foi estratégica. Hoje a internet tem um grande alcance de massa e possibilita comunicação rápida e direta de forma internacional. Uma série de revoltas se organizou com ajuda da internet, mas não nos limitamos a isso. 
4- Que canais de comunicação o coletivo usa (redes sociais, site, youtube, streaming)? Quais as dificuldades e limitações encontradas no uso dessas ferramentas?

Usamos o facebook, twitter, vimeo, SoundCloud, streaming, riseup e estamos construindo o site.Tirando o riseup o maior problema que enfrentamos é o monitoramento estatal e a censura moralista. O Riseup é uma ferramenta criptografada, criada e gerenciada por libertárixs para fins libertários, o que nos traz muito mais tranquilidade. Hoje, acreditamos que também sofremos por não ter acesso a equipamentos que permitem o uso desses canais. Não podemos os produzir (o sistema detem os meios de produção), e raramente temos dinheiro para comprá-los. Nosso coletivo, por exemplo, só tem um computador e não tem uma máquina fotográfica de qualidade, costumamos pedir emprestado.

5- São tomados cuidados para garantir a segurança das informações publicadas, como o software livre? O uso do riseup seria uma resposta à vigilância virtual?

Tomamos todos os cuidados dos quais temos acesso hoje. Usamos softwares livres, inibidores de ip, canais criptografados e não temos perfil pessoal no facebook. $\mathrm{O}$ uso do riseup é, sem dúvidas, uma resposta à vigilância virtual.

6- Quem são os parceiros do coletivo? Que afinidades os unem e como a internet é usada pra articulá-los?

Temos uma infinidade de indivíduos e coletivos parceiros. Todos são autônomos, a maioria se intitula libertário e/ou anarquista. As afinidades costumam ser um posicionamento antissistêmico e antiautoritário. A internet nos permite conhecer o trabalho de muitos desses coletivos e então buscar uma forma de se comunicar segura.

7- Desde o ano passado, coletivos autônomos tentam se unir e se fortalecer. A rede Protesta é um exemplo dessa tentativa. O coletivo AIA faz parte dessa articulação?

Não.

8- O que significa \#aredenarede, hashtag frequentemente mencionada na página do coletivo no Facebook?

Acreditamos que os autônomos formam pequenas redes de afinidades e colaboração, que formam uma rede ainda maior. Essa sessão do AIA tem intenção de divulgar na rede (internet/web) aquilo que acontece na rede autônoma.

9- O foco do coletivo é fazer a cobertura de protestos nas ruas e compartilhar informações via redes sociais? 
O foco do coletivo é buscar as maiores necessidades dxs oprimidxs e lhes dar espaço para livre criação e divulgação. Pretendemos fazer um jornalismo feito pelo povo e para o povo. Sem interesses partidários ou financeiros. De acordo com as necessidades que vamos percebendo, vamos desenvolvendo nossas atividades. Acreditamos que um jornalismo livre faz parte de uma educação libertária, e ambos precisam garantir acesso à informação não manipulada.

\section{9- Quais as expectativas para o mês da Copa do Mundo?}

Muitos protestos nas ruas, repressão policial e perseguição estatal. Nós decidimos manter nossas atividades em okupações, periferias, protestos e internet, mesmo sabendo dos riscos. Apesar do Coletivo AIA ser recente, seus integrantes não começaram em Junho de 2013 e não pretendem parar depois da Copa.

\section{0- Como a comunicação pode contribuir para a transformação concreta da sociedade, ou seja, para a destruição do capitalismo?}

Acreditamos que já respondemos essa pergunta anteriormente, mas frisamos que a ruptura e emancipação só serão possíveis através do conhecimento. Entendemos que a anarquia é o uso livre da consciência. As pessoas têm suas mentes dominadas desde seus nascimentos, levadas a crer que o ideal é a manutenção do status quo. E assim, crescem reproduzindo o consumismo, a alienação, o racismo, a xenofobia, o machismo, a lesbo/homo/trans fobia e o autoritarismo. Somente quando temos acesso à informação e nos unirmos através do diálogo é que poderemos nos organizar de forma autogestionária e horizontal. 


\section{ANEXO D: ENTREVISTA COM FERNANDO E MURAI, DO COLETIVO DESOBEDIÊNCIA SONORA}

Data: $28 / 01 / 14$

\section{Entrevistado 1}

Nome e/ou codinome: Fernando

Formação: História

Ocupação: professor

\section{Entrevistado 2}

Nome e/ou codinome: Murai

Formação: Comunicação Social

Ocupação: publicitário autônomo

\section{1-Por que você entrou no coletivo?}

Murai: Não entrei no coletivo por política, mas por acreditar em um projeto que já existia, que é um projeto de mídia alternativa. Tem a ver com o que eu faço profissionalmente que é comunicação e gravação de bandas, então acho que casou. Não sou de nenhum partido. Eu sempre tive muito a pegada do "do it your self”. Já trabalhei na grande mídia, mas estou apostando mais em experiências autônomas.

Fernando: Eu vim do meio punk, do envolvimento com bandas. A partir vivências fui amadurecendo uma consciência política, o que possibilitou o estudo do anarquismo. $\mathrm{O}$ Frequência Damata existe desde 2007 e eu entrei em 2008. Até então, eu nunca tinha feito parte de nenhuma outra organização ou coletivo por não ter interesse. No ano passado eu me juntei à Casa Mafalda. Minha atuação sempre foi no meio punk. Inicialmente, o podcast era feito com outras pessoas e outra proposta. Tinha DJ, jornalista, pessoas voltadas para o cinema. Era uma coisa meio pop, meio indie. Quando entrei junto com o jornalista Jean, no Jaçanã, a gente amadureceu. A experiência política se deu sempre no meio anarquista.

\section{2-Como vocês se conheceram?}

Murai: Eu fazia parte do coletivo Casa Mafalda e o Konesuk fazia muitos shows aqui. Esse projeto estava parado porque ele não tinha estrutura e eu forneci essa estrutura porque eu tenho um estúdio.

Fernando: O programa era gravado no estúdio Damata, no bairro do Jaçanã, aí houve uma ruptura com o dono do estúdio Damata. A gente decidiu não mais fazer lá e ficou parado. Durante esse tempo que estava parado, a gente ficou procurando lugares até aparecer o Murai. A gente tinha um equipamento mínimo: microfone, fone e pedestal que a gente conseguiu com o VAI de 2012. Aí o Murai possibilitou toda a parte técnica e de estrutura. Desde agosto de 2013 a gente vem desenvolvendo o programa.

\section{3-Por que houve essa ruptura?}


Fernando: Por uma questão política. Em 2012, a gente conseguiu verba através do edital do Vai e em 2013 passamos novamente. Aí o dono do estúdio falou que não tinha mais interesse em desenvolver o projeto porque ele queria direcionar da forma que ele quisesse. Nós queríamos um trampo autogestionário e horizontal onde todos possam contribuir de forma coletiva. A gente publicou uma carta aberta na época.

Antes de eu entrar, cinco ou seis pessoas produziam o podcast com funções rotativas. Quando eu entrei só tinha o Jean, que era o jornalista, e o Daniel, dono do estúdio Damata. Depois de um tempo entraram outras pessoas fazendo fotos, cartazes e escritos. É importante salientar que nem todos, no decorrer da atuação do podcast, são anarquistas. O Tiago, que faz alguns textos para o podcast, é do PSOL de Guarulhos e atua no Passe Livre lá, mas se encaixa dentro da nossa proposta de mídia alternativa.

Murai: Eu também não sou anarquista.

\section{4-Quais são os critérios para alguém participar do coletivo?}

Murai: Tem que ter alguma ligação com a cultura do "faça você mesmo" de coletivos autônomos. A gente mais dá voz aos outros do que dá a nossa visão. Geralmente os podcasts são entrevistas. Eu acho que o viés é mais ou menos de esquerda.

Fenando: A nossa bandeira é por uma mídia alternativa, por uma mídia que seja feita de outra forma. Quanto menos a gente puder aparecer, melhor. Tanto é que nas entrevistas, quanto menos a gente se expor e quanto mais a pessoa falar, melhor.

\section{5-Por que a necessidade de criar o coletivo Desobediência Sonora?}

Murai: O coletivo abrange muito mais coisas do que o podcast. Além do podcast, há textos, resenhas musicais, notícias do underground, agenda de shows - coisas que não saem na grande mídia. Ainda tem o festival mensal que a gente faz na Casa Mafalda que traz muitas bandas que passam pelo programa. A gente faz a coisa toda: fala com eles, vê e documenta o trabalho deles e abre espaço.

Fernando: O festival "Desobediência Sonora" junta grupos de punk, grind, metal e afins com o meio rap e a formação política. O objetivo é juntar tudo o que a gente faz no podcast de uma forma vivenciada, em termos geograficamente limitados à Casa Mafalda. Mistura todo esse público e se faz uma formação. No próximo festival, vai ter uma intervenção poética. O último teve a participação do Movimento Autônomo pela Educação (MAE). Estamos há um ano com o festival mensal, sendo que a grande maioria acontece na Casa Mafalda; mas já foi em outros lugares como Suzano, Ipiranga, Mooca. A formação política reúne todos pra uma conversa sem rigor acadêmico. Uma formação que possa chegar aquele punk que tem o ensino médio, que não vai entender nada do que um acadêmico falar pra ele. Então se dá através de uma conversa, da troca de ideias, da construção da informação.

Murai: A gente sempre traz um convidado, um especialista no assunto. $O$ tema da entrevista no podcast é aprofundado num ambiente diferente. O último festival teve show de punk e rap e a participação de professores de 50 anos. Então é interessante discutir educação e logo depois ouvir um hardcore.

Fernando: Acho que a nossa ideologia é a mídia independente. O nosso objetivo é divulgar o que está sendo feito. A gente trabalha de forma autogestionada e horizontal 
com uma visão de esquerda. As nossas bandeiras políticas refletem o que as pessoas podem contribuir na formação.

Murai: O faça você mesmo não chega a ser uma ideologia, é mais uma postura.

\section{Como o coletivo se financia e organiza suas tarefas?}

Murai: Financeiramente a gente tira do próprio bolso. Atualmente cinco pessoas participam. A gente está pensando em trazer convidados principalmente pra parte de texto.

Fernando: Cada um tem a sua função. Se alguém quiser mais função ou menos função, a gente trabalha de forma tranquila em relação a isso. Em dia de gravação, eu e Murai sempre estamos aqui. Se alguém dentro coletivo quiser fazer a entrevista e falar, tudo bem. As gravações são abertas. As funções dentro do coletivo podem se mover tranquilamente.

\section{6-Vocês costumam se reunir pra discutir problemas e demandas do coletivo?}

Murai: Como cada um mora em um canto da cidade, é comum a gente discutir pela internet. Por ser um trabalho fruto de ativismo, a pessoa trabalha de graça. Se ela se vê em uma posição subalterna, por que ela faria isso?

\section{7-Como vocês lidam com a Internet? Como esse meio facilita o trabalho do coletivo? Existem limitações?}

Murai: A gente não se preocupa tanto com a segurança da informação na Internet porque não há com o que se preocupar. A gente vai pelo o que é mais prático. A meu ver, a grande vantagem é a praticidade porque você acessa de casa e pode debater vários tópicos ao mesmo tempo. Em reunião presencial ficaria mais difícil. Usamos geralmente e-mail e facebook. Esse projeto só existe por causa da Internet.

Fernando: Dificilmente a gente colocaria uma antena e iniciaria uma rádio comunitária com toda a problemática que isso envolve.

Murai: E também serve como armazenamento. Não é só a edição da semana que importa. A gente vai construindo um repertório de entrevistas que ao longo do tempo se torna relevante.

Fernando: Se você quiser entender a conjuntura das movimentações, o podcast tem muito a contribuir para essa discussão.

\section{8-Como é feita a seleção de músicas?}

A música veiculada pelo podcast é predominante independente. Quando o entrevistado é musical, a gente geralmente põe música dele. Quando o convidado é de algum movimento, muitas vezes a gente põe músicas que o próprio convidado pede.

Fernando: Quando a gente entrevistou o pessoal da Baderna Midiática, que publicaram no blog do coletivo um material sobre as músicas de revoltas, a gente colocou o hino à rua, composto por eles, e outras músicas que eles pediram, como a da Comuna de Paris.

Fernando: O Murai frisa que a gente precisa ter mais cuidado no sentido de estudar outros podcasts pra que a gente tenha um repertório mais extenso e possa desenvolver 
coisas diferentes. Mas eu escuto pouquíssimos podcasts, como o pessoal do Cordel Libertário, a rádio da juventude de Santos. Eu não encontrei nada parecido com a formatação que a gente faz.

Murai: Quanto eu entrei no projeto, eu nunca tinha feito um podcast nem era um consumidor de podcast. Aí a gente parou pra pensar em um novo formato.

Fernando: A gente não dispunha dessa parte técnica do Murai, dessa experiência que ele tem nas mídias sociais, dessa leitura que ele faz do formato. A gente é punk, então fazia e soltava. Aí o Murai fez a gente pensar na estrutura, na vinheta...hoje está bem melhor.

\section{9-Como é o processo de produção do programa?}

Fernando: A gente agenda a entrevista. Antes da gravação, a gente anuncia o programa na internet. Durante a gravação, o Murai faz fotos e vídeos. Depois ele faz o trabalho de edição. Normalmente eu crio as perguntas, mas a gente também abre pra perguntas no facebook.

Murai: A gente edita e mixa com as músicas e vinhetas. Atualmente cada programa tem uns 45 minutos. Aí a gente coloca no nosso site dedobedienciasonora.com. A gente optou por colocar o podcast no youtube em vez de colocar como mp3. O youtube facilita bastante o compartilhamento. A gente usa as próprias redes sociais da internet como ferramenta gratuita. Depois a gente compartilha esse post no Facebook.

Fernando: A gente não tem uma vasta divulgação.

\section{0-Todos os programas estão no site?}

Fernando: Antes, a gente colocava numa conta não paga do soundcloud. Ficava um tempo e depois era substituído por uma nova edição. A gente fazia o download da edição anterior numa pasta zipada do 4 shared. Com o site, a gente tem a possibilidade de guardar o histórico de outra forma. A gente ainda não concluiu o processo de transferência dos arquivos para o site, é um trabalho gradativo. Hoje estamos na edição 59. Falta colocar 50 edições no site.

Murai: O site não tem nem um mês. Começou no dia 6 de janeiro. Agora tem seis programas publicados. A gente preferiu dar prioridade pras coisas novas. Conforme for arrumando tempo, a gente coloca as coisas antigas. É um trabalho importante, mas a gente não pode parar tudo pra fazer isso.

\section{1-Vocês participaram dos protestos de junho?}

Murai: Eu estava viajando.

Fernando: Minha atenção estava voltada pra atuação política na Fundação Casa. Eu não fazia parte de nenhum grupo. Eu participei dos atos em São Paulo, mas dei prioridade pros de Mairiporã e Franco da Rocha, que são roteiro das unidades em que eu trabalhava. Lá, as manifestações traziam mais a periferia e estudantes do ensino médio e fundamental. Em vez de protestar com um monte de boys, eu estava na quebrada fechando a Fernão Dias. Pra mim foi válido. Em grande parte, o objetivo era tacar pedra na polícia.

\section{2-O coletivo se articula com outros?}


Fernando: A gente tem uma parceria com a rádio Ponto Alternativo de Fortaleza, que transmite as edições do podcast. Mas a atuação política no sentido de levantar bandeiras eu acho improvável porque o nosso foco é a mídia independente e a divulgação da luta e da música de outras pessoas.

Murai: As coisas que eu fazia na Casa Mafalda eu não levava para o coletivo. A gente evita esse erro comum na esquerda que é se dividir pelas diferenças. A gente quer se unir pelas coisas que tem em comum. Eu não sou anarquista, mas quase todo mundo do coletivo é anarquista.

\section{3-Vocês planejam abordar os protestos contra a Copa no programa?}

Murai: As pessoas do comitê da Copa não têm voz na grande mídia e são tratados como vândalos. Resta à mídia alternativa dar voz pra essas pessoas. Com certeza a gente vai abrir espaço pra isso.

\section{4-Que dificuldades os coletivos autônomos enfrentam hoje?}

Murai: Tem a dificuldade financeira, que parece detalhe, mas não é. E essa coisa de se dividir pelas diferenças em vez de se unir pelas semelhanças. É comum haver racha quando opiniões divergem por uma questão que não tem nada a ver com a atividade daquele coletivo em si.

Fernando: Se um coletivo faz a gestão de uma casa, cai na questão financeira. Pensar em coletivo autônomo em São Paulo é pensar em diversas formatações. Desde a subcultural, no meio punk, até movimentos sociais e contextos acadêmicos. Cada um desses tem a sua particularidade. Como o Murai sublinhou, essas duas coisas são as principais. Dentro dessas estruturas de cada coletivo há dificuldades próprias.

Murai: Falta objetividade. Quem está em um coletivo como o MPL, que luta pela melhora do transporte coletivo, tem que discutir transporte. Tem que somar forças naquela causa em comum. Quando cada um traz a própria agenda para uma manifestação do MPL, vira palhaçada. Vai ter briga, racha.

\section{5-É importante unir causas concretas, como a redução da passagem, a causas aparentemente mais simbólicas como a liberdade de expressão?}

Fernando: Um grande desafio que se vê é você poder contar o que está acontecendo agora. Esse trabalho é feito por poucas pessoas e de uma forma frágil ao longo das últimas duas décadas. Dificilmente você consegue contar a história das manifestações, de coletivos e espaços autônomos em São Paulo de uma forma mais abrangente. Acredito que a gente vem preencher essa lacuna no sentido de que os próprios agentes contem a sua história, servindo como documento que pode ser utilizado como fonte.

Murai: Documentar o que está acontecendo é uma tarefa complicada porque você está colocando a sua visão. Uma coisa que eu acho muito legal nesse coletivo é que a gente chama os caras pra falar a versão deles, e não dá a nossa versão dos fatos.

Murai: Eu tenho prazer de trabalhar com gente que eu gosto. Nunca é um trabalho cansativo. É muito mais divertido atuar no coletivo do que assistir à novela. Você está sendo protagonista. Você vê um problema e quer resolver. Meu avô foi vítima da ditadura. O grande problema da resistência aqui era a comunicação. Não tinha internet, 
era muito difícil se comunicar. Hoje em dia a gente tem tudo isso e não vai dar voz às pessoas?

Fernando: A gente faz com que fique leve. Fazer o podcast é ver o problema e tentar resolver. É tentar contribuir pra memória dos movimentos sociais e da música independente.

Murai: A luta inicial do Anonymous é pela internet livre, uma luta super válida. A informática em sim diminui a distância entre o meio de produção e o operário. Às vezes, o cara que em outro século nunca poderia ser dono dos meios de produção acaba conseguindo ter acesso aos meios de produção por causa da Internet. É o caso da mídia alternativa. Há cem anos, seria muito mais difícil desenvolver esse trabalho sem um puto no bolso.

Fernando: A experiência européia com a internet ilustra muito bem. Tanto Turquia quanto Grécia. O bloqueio a internet em alguns países...

\section{6-Como é a recepção do podcast pelo público?}

Murai: A comunicação estava meio bagunçada, não tinha sido pensada. Neste mês começou o novo projeto. A gente não tem tempo suficiente pra medir as respostas. Com o site, a resposta aumentou muito. Cada entrevista tem o triplo de acesso que tinha antes. A tendência é aumentar, mas a gente não busca o público geral, até porque a gente não vende anúncio. Pra gente não interessa ter 5 milhões de pessoas acessando. A gente quer que as pessoas que se interessam mesmo acessem. Pra nós, não interessa a visualização pela visualização.

Fernando: É interessante que o cara que escuta reggae conheça a banda punk e o grupo de rap, que a banda punk conheça o movimento social. Proporcionar trocas e vivências é importante.

Murai: A gente compartilha o que a gente acha que é relevante, mas é preciso evitar o spam pra não perder o canal de comunicação. Se a gente compartilhar tudo o que os outros coletivos publicam, as pessoas vão parar de seguir a gente. Se a pessoa ouviu a entrevista e curtiu o coletivo, ela vai buscar os canais de comunicação daquele coletivo. Rede social é pra relacionamento, não só para divulgação. 


\section{ANEXo E: ENTREVISTA COM CAIO E FLÁVIA, DO MOVIMENTO MOINHO VIVO}

\section{Entrevistado 1}

Nome e/ou codinome: Caio Castor

Formação: ensino superior incompleto

\section{Entrevistado 2}

Nome e/ou codinome: Flávia

Formação: Artes visuais

Ocupação: professora

\section{1-O que desencadeou o movimento Moinho Vivo?}

Flávia: O Moinho tem uma luta de mais de 30 anos. Eles lutaram, começaram a construir a favela, cuidar do espaço, cuidar da terra e ocupar essa área. Quando a gente veio, no final do ano passado, a gente começou a conhecer como funcionavam as relações aqui dentro e como estava a associação de moradores. Todo mundo estava muito fragilizado por conta dos dois incêndios que tinham acontecido. A maioria das pessoas que eram da associação estavam fora da favela por terem perdido suas casas. Perto de junho de 2013 começou um processo de organização dos moradores. Eles se organizaram junto com o escritório modelo da PUC que dá assessoria jurídica e em 2006 montaram a associação de moradores. Em 2008 eles entraram com o pedido de uma tutela antecipada de usucapião e conseguiram. Isso garante que eles fiquem até o final do processo de disputa pela área. Há um grande nó jurídico de disputa do qual fazem parte uma empresa particular, a União, a prefeitura e os moradores. Durante a gestão do Kassab, houve vários incêndios em favelas situadas em áreas de especulação imobiliária. No dia 22 dezembro de 2011, houve um incêndio no Moinho que foi considerado por muita gente criminoso porque foram vários focos de fogo ao mesmo tempo. Alguns dias depois o Kassab conseguiu 3 milhões e meio de reais pra dinamitar o prédio, sob a justificativa de que a área estava em risco, mas não conseguiu derrubálo. Segundo a imprensa, duas pessoas morreram, mas os moradores encontraram vinte corpos incinerados. Depois disso, o Kassab isolou a área, que é metade do terreno da favela, e entrou com pedido de desapropriação. Então essa briga jurídica tem toda uma história de interesses imobiliários.

\section{2-Como vocês se envolveram com a mobilização em defesa dos moradores da favela?}

Flávia: depois do incêndio que aconteceu em setembro do ano passado, a prefeitura tentou isolar a área com barricadas e os moradores chamaram vários grupos que apóiam o movimento. Foi quando o Caio veio e a partir de novembro ele começou a morar aqui. E aí, junto com os moradores, começamos o projeto de intervenção nesse espaço subutilizado. No terreno doado por uma moradora construímos coletivamente a Casa Pública, que passou a ser o lugar onde as pessoas se reúnem. 
O Moinho é a última favela do centro de São Paulo. É um movimento de resistência não só por moradia, mas por outra lógica social. Aqui é a terceira área mais cara de São Paulo. Existe todo um projeto de enobrecimento, de especulação imobiliária, de especulações. É uma luta por direitos humanos.

\section{3-Por que o Moinho é um movimento autônomo?}

Flávia: Vem da história da ocupação da terra. A associação é aberta pra quem quiser participar. Não há uma liderança dando as direções. As decisões são tomadas em assembleias. Houve épocas em que as assembleias ocorreram de quinze em quinze dias, mas hoje não está tendo mais. Como são muitos anos de lutas, a associação tem força e existem moradores que são lideranças natas como o Miltão, a Alê, o Humberto. A mobilização é um trabalho de construção que leva um tempo. A gente está construindo aos poucos com as pessoas. A gente tomou a frente da organização da ação do dia 14, é uma parte da ação prática do nosso projeto. É do interesse de todo mundo recuperar esse espaço de uso comum. Assim como a instalação de luz, água e esgoto, o acúmulo de lixo foi uma questão discutida com a prefeitura.

O projeto Comboio foi criado para discutir a lógica da cidade junto com as pessoas. $\mathrm{O}$ movimento é autônomo porque luta pela permanência e porque as pessoas estão cansadas de esperar que a prefeitura faça as melhorias. $\mathrm{O}$ nosso projeto quer pensar isso e dar força pra essas iniciativas. O que une a nossa ação é uma pesquisa sobre a cidade que inclui urbanismo, direitos humanos, que discute a especulação imobiliária, os abusos de poder, as relações das empreiteiras com a prefeitura, as negligências do Estado. E, junto com isso, pensar ações práticas de disputa pela área.

Caio: A maioria é trabalhador informal. Alguns têm trabalho registrado, outros são pequenos comerciantes, outros trabalham em empresas terceirizadas pela prefeitura que prestam serviço de limpeza, podas de árvore...

Caio: Quando lhe foi oferecido um apartamento de 150 mil reais durante uma reunião com a Secretaria de Habitação, o Miltão, um morador da favela, criticou a política de higienização do centro e perguntou: "Você está me oferecendo esse apartamento porque meu filho é preto, pobre e favelado? Pra que ele more na periferia?". Depois disse que "nenhum político desse país tem consciência desse estado político cultural chamado favela". O secretário continuou oferecendoo apartamento, e o Miltão questionou: "que indenização vai pagar as amizades do meu filho que foram desfeitas?". É um exemplo do que os moradores, no geral, sentem, o que expressa a vontade de viver em comunidade. $\mathrm{O}$ fato de querer ficar aqui, nesse espaço, reflete a vontade da comunidade de manter essa estrutura coletiva.

Flávia: As pessoas moram há muito tempo aqui e têm uma relação umas com as outras.

Caio: Tem uma coisa da dificuldade muito grande de morar nesse espaço por conta da falta de água, luz e esgoto e do risco iminente de incêndio, uma das coisas que mais levam as pessoas a querer sair daqui. Porém, há um espírito coletivo muito forte.

\section{4-Como vocês comunicam as atividades do Moinho?}

Caio: A gente registra absolutamente tudo, como uma arma de contra-informação tanto pra dentro quanto pra fora. Na primeira assembléia que a gente puxou com os moradores em junho, a gente exibiu um vídeo da Internet feito pela Agência Pública que mostra o Haddad em período de campanha prometendo regularização fundiária e 
urbanização da área. A gente mostrou algumas partes desse vídeo, que tinha sido visto por poucos moradores, pra todo mundo. Faz mais de sete meses que ele assumiu e até agora não fez nada. Assim nasceu o primeiro ato. Quando a gente chegou à prefeitura, chamaram uma comissão para uma reunião. A gente entrou na prefeitura gravando e exigiu que a reunião fosse gravada na íntegra pra mostrar pros moradores. Exigimos que as próximas reuniões fossem na favela pra que todos participassem e passamos a gravar todas as reuniões que aconteciam na prefeitura. $\mathrm{O}$ jeito de dar vazão a esse material foi a Internet, através do Facebook. E começamos a disponibilizar esse material lá tanto para dialogar com movimentos quanto para publicizar uma outra versão da história que até então não tinha sido contada. Aí a gente começou a pensar como essa comunicação podia ser feita. A edição dos textos era construída junto com a associação. O material ficou bem fiel ao desejo dos moradores. A Internet acabou servindo como um instrumento de mobilização tanto pra fora quanto pra dentro.

Flávia: gente usa o celular e equipamentos emprestados de parceiros. O Caio tem uma câmera e eu um computador. A gente tem parceiros que vêm e filmam, como o Luciano e o Flávio. Essa estratégia de contra-informação tem a ver com a legitimidade do diálogo no sentido de enfraquecer as relações de poder que a prefeitura estabelece ao tentar fazer negociações com poucos moradores a portas fechadas.

\section{5-Quem são os coletivos parceiros do Moinho?}

Caio: Movimento Mães de Maio, Passe Livre, Rede Dois de Outubro, Instituto Práxis, Ação Direta de Vídeo Popular, pessoal do hip hop - o Miltão é um dos fundadores do Racionais MCs e um dos fundadores do hip hop no Brasil. O nome Moinho Vivo surgiu antes da gente chegar aqui. Depois do primeiro grande incêndio, houve um show do Mano Brown e mais de vinte grupos de rap. Também tem os saraus da periferia, do Luta Popular, pessoal do teatro.

\section{6-O que os aproxima?}

Caio: A identificação com a luta do Moinho, a não institucionalização do movimento, a não ligação com nenhum partido político, o fato de não ser um movimento tradicional. É uma coisa feita pelos moradores, para os moradores, sem nenhum interesse outro por trás. O fato de ser um movimento autônomo aproxima as pessoas. O Moinho criou um simbólico de resistência muito forte por ser a última favela do centro de São Paulo, evidenciando as contradições do sistema político da democracia representativa do sistema capitalista. Em torno da região, num raio de vários quilômetro, não há um lugar sem luz, água e esgoto. Aqui você vê a polícia andando com fuzil, a dois quarteirões daqui não se vê isso. Eu sinto que o Moinho tem o apoio da opinião pública. Não tem outra explicação a não ser higienização, preconceito e discriminação.

\section{7-Vocês consideram o Moinho um movimento anticapitalista?}

Caio: Sim, com certeza. É uma luta direta contra o sistema. Entra político, sai político e continua a mesma coisa. É muito forte a consciência de que os inimigos são as grandes empresas, o capital imobiliário que vai lucrar com essa terra que é a terceira área mais valorizada de São Paulo.

\section{8-Quais as expectativas do movimento daqui pra frente?}

Caio: A curto prazo é conseguir luz, água e esgoto. Autonomia no sistema em que a gente vive é quase impossível. A autonomia é uma busca, uma construção. Uma das 
etapas dessa luta é conseguir do Estado luz, água e esgoto. Eu acredito que até o meio do semestre que vem comecem as obras desse plano emergencial. A longo prazo é conseguir a posse dessa área aqui.

\section{9-A comunicação fortalece o movimento?}

Caio: Eu acho que é uma soma. A gente é só mais um aqui dentro. Eu não acho que a gente faça grande coisa. A força está no fato de ter pessoas como o Klaus, o Alê, o Miltão, o Tião, a dona Francisca que está aqui há mais de 25 anos. Claro que a gente também propõe e fortalece.

Klaus: Depois que vocês entraram o movimento ficou mais divulgado e teve mais apoio.

Flávia: A ferramenta que se tem é universal.

Caio: O nosso lance é ser retaguarda do movimento, não é ser vanguarda. Eu não me coloco a frente pra falar pelo Klaus ou pela Alê. Todos os nossos textos e vídeos têm a voz dos moradores. Acho que é isso que dá a força. A gente tem as ferramentas, mas muitas das imagens feitas aqui - de ações policiais, principalmente - são registradas pelos próprios moradores. Mas o que mais fortaleceu foi a criação desse espaço [a casa pública]que conseguiu aglutinar grupos de fora que já tinha ações pontuais aqui e pessoas de dentro que estão a fim de lutar. A criação desse espaço influencia e fortalece a comunicação. A Casa Pública é um espaço onde todas as informações estão disponíveis - documentos com a tutela antecipada do usucapião, boletins informativos, vídeos. Outras ações pensadas pra esse espaço: fazer um mural de informação e assembleias. O ato do muro começou aqui dentro e a internet foi uma ferramenta usada pra divulgação que não pode ser subestimada nem superestimada. $O$ fato da gente colocar tudo o que a gente faz no Facebook cria um canal de comunicação que nos torna independentes da imprensa pra divulgar os nossos atos. Tudo o que a gente colocava na internet repercutia na imprensa, que vinha nos procurar. Quando a imprensa faz a cobertura, a prefeitura é obrigada a responder.

A gente deveria proteger as informações publicadas na Internet, mas não o faz. Vários amigos nossos fazem conversa sobre segurança na internet. Geralmente quem faz isso é uma galera que manja mais de internet. Eu tenho rise-up, mas ninguém mais aqui tem. Se derrubarem nossa página no Facebook, fudeu. O blog hospedado no Milharal não está todo atualizado. É uma preocupação que a gente não conseguiu resolver. 


\section{ANEXO F: ENTREVISTA COM FELIPE, DA CASA MAFALDA, E RAPHAEL, ATIVISTA SEM VÍNCULO COM COLETIVOS}

Data: 15/04/14 (durante o $5^{\circ}$. Ato "Se não tiver saúde não vai ter Copa")

\section{Entrevistado 1}

Nome e/ou codinome: Felipe

Formação: Rádio TV, parcialmente

Ocupação: trabalhador autônomo

Idade: 26

\section{Entrevistado 2}

Nome e/ou codinome: Raphael

Idade: 27.

Formação: Jornalismo

Ocupação: free-lancer e professor particular de inglês.

\section{1-Por que você está no ato contra a copa?}

Felipe: Eu sou do coletivo Casa Mafalda, que é um espaço autônomo de ideias libertárias onde promovemos debates com movimentos sociais, atividades artísticas e culturais, grupos de estudos, exibição de filmes e festas para a manutenção da casa. A Casa Mafalda existe desde 2011. Eu vim pra rua há uns oito anos como autonomista mesmo. Nunca fui filiado a nenhum partido. Acho que a organização dessa manifestação teve alguns equívocos. Tem uma galera nova chegando sem muita referência do que fazer na rua e movimentos que surgiram após junho com uma ânsia muito grande de vir pra rua e se manifestar. Essa vontade acabou atrapalhando quem já estava na organização de movimentos sociais e articulações de rua, como o MPL. O Comitê Popular da Copa, que tem a pauta da Copa há mais tempo, não conseguiu ter um diálogo muito sólido com a organização do "Não vai ter copa". A gente podia estar numa unidade com um número muito maior se as organizações tivessem se articulado melhor. Não acho que essa manifestação tenha a maior pauta no slogan "Não vai ter copa", mas eu acho válida. Eu estou aqui porque acho que tem que somar. Querendo ou não tem muitas pessoas aqui que estão dando a cara a bater pra polícia, com vontade de mudar mesmo. Eu vim pra checar e de alguma forma prestar solidariedade a quem está lutando e pode sofrer algum abuso da polícia. O Comitê Popular da Copa vai chamar o pessoal do "Não vai ter copa" pra participar de outros atos como a Marcha da Maconha e o $15 \mathrm{M}$.

Raphael: No ano passado, teve manifestante preso por lei de segurança nacional; os caras estão querendo aprovar lei antiterrorismo; numa das manifestações do não vai ter copa, a polícia fez caldeirão de Hamburgo. A gente tem que se organizar bem pra ir forte pra rua. Não adianta a gente querer ir de qualquer jeito. 
Felipe: Ser contra a copa é uma pauta muito vaga. Quem é de direita e tem tendências fascistas também pode falar "não vai ter copa" justamente porque o governo do PT é muito perseguido pela direita. É por isso que tem muito infiltrado nessa manifestação.

Raphael: O grande erro dessa crítica da direita ao PT é que o pessoal da direita simplesmente ignora que o PT não está fazendo nada de diferente do que foi feito na época do Fernando Henrique Cardoso, Collor, Sarney, dos ditadores militares... É simplesmente uma continuidade disso tudo. Tudo o que eles fazem é espernear nos meios de comunicação que são de propriedade deles. Quem faz uma oposição séria e inteligente não só ao governo, mas ao sistema em geral, ao capitalismo, a todos os governos que a gente já teve nesse país. As vozes das pessoas que estão nas ruas, independente de ser uma pessoa mais articulada ou não, não são ouvidas por esses meios de comunicação. E quando elas são ouvidas, são editadas, distorcidas e às vezes até inventadas - a Veja inventa declarações. Dentro do meio jornalístico, todo mundo já sabe disso.

\section{2-Como vocês usam os meios de comunicação pra divulgar as reivindicações?}

Raphael: Há duas maneiras. Uma é como ativista. Como ativista, a gente organiza debates, eventos culturais com caráter político. As pessoas saem nas ruas, colam cartazes, fazem sites na Internet e blogs divulgando conteúdos. Como jornalista, essa é a minha profissão, eu venho às manifestações e fotografo e entrevisto as pessoas com um gravador igual o seu. Eu faço matérias que tentam dar voz às pessoas que estão nas ruas, que têm motivo pra estar nas ruas e tem alguma coisa a dizer, e não as imbecilidades que a gente vê na televisão, nos grandes jornais e nas revistas semanais.

Atualmente eu não tenho feito parte de nenhum coletivo por uma questão de tempo. Eu estou sem tempo pra me dedicar, mas já participei da Casa Mafalda, do Centro de Mídia Independente, de coletivos de ocupação...

Felipe: O caminho da comunicação é esse mesmo. Criar nossa própria mídia pra poder se articular com as pessoas certas e poder fazer o filtro. Em junho, a direita se apropriou da manifestação de quem estava há muito tempo nas ruas. E a gente tem que vir aqui presencialmente conversar com quem é próximo e pelo facebook também, por mídia virtual.

\section{3-Como anda a articulação da rede Protesta?}

Felipe: Eu ouvi falar muito por fora. Eu não estou muito por dentro dessa articulação. Desde junho, movimentos autonomistas estão se reunindo para fazer uma rede para conectar os movimentos sociais. Ainda não está tão grande, mas está rolando inclusive com o MPL, o Comitê Popular da Copa, algumas frentes de luta por moradia e da periferia.

Raphael: Por serem diversos coletivos com pautas e objetivos distintos, é muito difícil fazer essa organização. Eu não posso dizer muito sobre a tentativa que aconteceu ano passado, mas o que eu sei é que houve uma tentativa e agora está havendo outra.

Felipe: A gente não pode vir pra rua com o objetivo de derrubar a copa. A questão não é essa. A gente tem que usar as pautas possíveis pra fortalecer a luta da revolução. As grandes transformações sociais do país vão acontecer com ou sem a Copa do Mundo. A gente tem que ter a mesma unidade depois da Copa. 
Raphael: A Copa é um gancho pra gente puxar esses assuntos. É uma coisa que está na rua, na cara de todo mundo, mas não é o principal. A gente tem que usar a Copa pra colocar as pautas que realmente vão ter um interesse popular de longo prazo. A Copa é daqui a um mês e meio, todo o estrago dela já está feito. Ela é só uma maneira de puxar o debate pra que a gente possa lutar contra esses novos estragos e também contra os estragos seculares.

Felipe: E fortalecer outras pautas que são mais urgentes do que a Copa do Mundo, como a desmilitarização da polícia que está matando há décadas impunemente pelas ruas de São Paulo e do Brasil todo. Como o país vai ser militarizado na Copa do Mundo, está escancarado que a gente ainda tem fortes resquícios da ditadura militar. Os militares estão na rua fazendo o que bem entendem, ocupando favela no Rio, desapropriando famílias...

Raphael: E por falar em 64, esse dia lamentável da nossa história faz 50 anos. Uma coisa importante para citar é a luta pela verdade, pela responsabilização e punição dos torturadores e daqueles que auxiliaram a tortura de alguma forma.

Felipe: A pauta da desmilitarização não é só da desmilitarização da polícia, mas da política. A política que a gente tem é ainda nos moldes do regime militar. A polícia é só um instrumento usado pra nos combater diretamente nas ruas. Há toda uma lógica militar por trás dos próprios militares.

\section{4-Como vocês avaliam a presença no ato de movimentos ligados a partidos políticos como Juntos (PSOL) e ANEL (PSTU)? Os coletivos autônomos tentam se articular com eles?}

Felipe: A gente tenta se articular e já se articulou. Mas nessa manifestação eu tenho a impressão que convém a eles pegar esse pessoal que não tem muita referência da rua pra cooptarem pro partido. Eu, como anarquista, não acredito mais nessa luta partidária. Essa manifestação parece às vezes um desfile de partido que procura gritar mais que o outro, sem uma unidade.

Raphael: A gente não escolhe $\mathrm{X}, \mathrm{Y}, \mathrm{Z}$ pra se articular. A gente tenta se articular com todo mundo. Os grupos que mantêm uma afinidade de estratégia e pauta continuam articulados e os que não mantêm acabam tomando outro rumo, isso é natural. O que une a gente é a miséria em que nossas vidas se encontram. $O$ fato da pessoa se identificar com uma ideia ou com outra é secundário.

Felipe: A gente tem pautas em comum com os partidários. A gente questiona quando o partido tem uma estratégia de benefício próprio e não da luta como um todo. 


\section{ANEXO G: ENTREVISTA COM ANDRÉ NICÁCIO, DO COLETIVO BADERNA MIDIÁTICA.}

Data: $31 / 01 / 14$

Formação: História

Ocupação: professor

Entrevista com André Nicácio, do coletivo Baderna Midiática

\section{1-De onde vem seu interesse pelo ativismo?}

O meu envolvimento com a militância política vem da adolescência. Participava de grupos anarquistas e coletivos pequenos. Participava também do movimento estudantil no colégio técnico onde estudava que tinha grêmio. Em 2002 eu entrei na USP, ano em que houve um movimento muito vigoroso que foi a greve da FFLCH. Tive certa aproximação com o CMI naquele contexto. Participei de algumas reuniões, mas acabei não me envolvendo realmente. Depois disso tive participação intermitente em movimentos políticos. Não tive envolvimento orgânico ou uma atuação constante. Participei do movimento estudantil da USP em alguns contextos e em outros não. No contexto das manifestações de junho, eu participei dos atos. Eu e algumas pessoas conhecidas ou amigas que não sabiam como atuar naquele momento de efervescência política começamos a nos articular. O Baderna Midiática surgiu dali. A primeira tentativa de reunião aconteceu entre final de junho e começo de julho. Havia uma percepção da demanda de uma disputa através de redes sociais, das formas de mídia de que a gente tinha alcance, que não fosse uma cobertura jornalística, mas outro tipo de produção midiática. Uma articulação de um discurso contra-hegemônico, contra o discurso da grande mídia, uma disputa simbólica do sentido das manifestações. Isso veio um pouco das tentativas de articulação do movimento autônomo em São Paulo. Houve algumas reuniões em junho e julho que foram muito grandes. Eu me lembro que uma das grandes coisas que apareceram ali era a percepção de que embora nós tivéssemos muito mais familiaridade com as redes sociais do que a direita, nós estávamos perdendo pra direita justamente no nosso terreno. Perder a disputa da internet era uma derrota terrível pra esquerda autônoma. Num primeiro momento, quem puxava os atos e mobilizava era o MPL, um movimento autônomo. Num segundo momento, aquelas páginas de facebook sem nenhuma transparência do que se trata e quem está por trás daquilo como Anonymous e Change Brasil começaram a dirigir o sentido que aquilo estava tomando, seguindo as pautas ditadas pela grande mídia.

O número de pessoas é muito variável porque a gente se organiza por ações. Tem um universo de vinte a trinta pessoas que costumam participar de uma coisa ou outra dentro do coletivo. Tem um grupo em torno de seis a sete pessoas que atua com mais frequência, ajuda a manter a produção de conteúdo pra página e costuma estar na maioria das ações.

A nossa primeira reunião foi em julho na Casa Mafalda. Quase todas as reuniões foram feitas lá porque mais da metade das pessoas mora na região. Nós não tivemos uma formação como coletivo pensando na organização a longo prazo e nos princípios. Como estávamos vivendo um momento muito intenso, de necessidades imediatas, resolvemos fazer coisas e discutir a nossa organização com o tempo, conforme as divergências fossem aparecendo. A proximidade com os movimentos autônomos era clara. Todas as 
pessoas envolvidas se identificam com pessoas de esquerda, socialistas ou anarquistas. Nenhuma delas tem filiação partidária ou se identifica diretamente com algum partido.

\section{2-O que motivou a criação do "hino à rua"?}

A ideia da nossa primeira ação, o Hino à rua, era disputar a memória dos protestos de junho. Um vídeo com uma música que vai registrar o que foi aquilo pra que se contraponha ao que está sendo construído. A gente dividiu as tarefas de acordo com a disponibilidade de cada um.

A produção do vídeo ficou concentrada em poucas pessoas porque a gente tinha que correr pra que ficasse pronto antes que o assunto saísse de pauta. Eu compus a letra com opiniões de outras pessoas. A melodia foi feita pelo Tiago com base numa canção antifascista italiana. A Cris fez quase tudo em relação à gravação e edição de áudio. Ela e eu fizemos a edição de vídeo. O Virgílio cantou com algumas pessoas que formaram um coral.

Depois disso, a gente começou a organizar nossas listas de emails e páginas de forma que as atividades não se concentrem em poucas pessoas. A ideia era dividir as tarefas pra que o maior número possível de pessoas participasse. A gente não delimitou o tipo de produção. A gente pensou em fazer outros vídeos, textos e imagens. Eu tenho uma experiência de internet muito mais ligada ao humor. É uma forma de política que eu faço desde a adolescência. Hoje em dia eu tenho três páginas no Facebook de humor político. Então eu queria incorporar essa produção às atividades do coletivo. Passei a vincular minhas páginas ao coletivo e a consultá-lo sobre o tipo de produção que eu ia fazer. As páginas "A Revolução será orkutizada", "Agrega valor ao camarote" e "Manifestante da depressão" são de humor por conta da facilidade de viralização.

\section{3-Que potencialidades você vê no uso da internet?}

Eu não acho que a Internet seja a razão das mobilizações, mas a influência é muito grande em termos da facilidade de articulação. Antigamente, coletivos de comunicação eram restritos espacialmente com baixo impacto. A Internet inova de uma maneira muito grande. No futuro as pessoas vão ter noção do seu impacto e sobre a estrutura de poder e de controle da informação. Isso não significa que ela seja necessariamente uma democratização. Ela concentra de maneiras diferentes, ela é muito capciosa por conta das redes sociais serem empresas privadas que controlam aquilo da maneira que querem e podem ser pressionadas pelo Estado da maneira que o Estado quer. As páginas do movimento "Não vai ter copa" estão saindo do ar. Mas acho que a Internet teve um impacto tão grande quanto a generalização da imprensa, da tipografia porque ela desconcentra o foco de produção e dissemina muito mais rapidamente uma informação que não se quer em circulação. A gente não pode romantizar e achar que tem toda a liberdade na Internet e que a gente disputa de igual pra igual com outros meios. A gente tem um certo espaço e uma possibilidade de atuação, mas quando eles derrubam a nossa página quando quiserem. A internet é uma ferramenta importante que precisa ser disputada.

\section{4-Por que ser autônomo?}

Da minha parte, vem das experiências políticas anteriores. A forma de atuação partidária se descola das diversas lutas sociais, seja de organizações de base, seja de uma militância de comunicação como a nossa, em prol de uma estrutura de poder que 
tem como finalidade a disputa eleitoral e que subordina tudo a isso - embora existam partidos da extrema-esquerda que se formalizam em uma dinâmica eleitoral, mas se colocam como partidos revolucionários. Não seria possível um tipo de organização que gerasse o que a luta contra a tarifa gerou se aquilo fosse um movimento o tempo todo articulado dentro de organizações partidárias ou subordinado a interesses de organizações partidárias.

A organização autônoma não está assimilada e cooptada de antemão, abre espaço pra se pensar na prática como o poder não é algo natural. A organização autônoma desnaturaliza a relação com o poder no cotidiano. Uma organização que se pretende revolucionária com um partido centralizado e mantém uma estrutura centralizada e burocrática nunca vai ser uma estrutura revolucionária porque ela não permite um aprendizado no seu cotidiano do que é viver a política sem ser simplesmente uma correia de transmissão de uma estrutura de poder organizada. Dar a devida importância aos resultados sem abrir mão do processo, das experiências de cada um dos envolvidos nessa luta.

O Baderna Midiática é anticapitalista porque não combate apenas a estrutura de poder no sentido estatal, senão poderia se aproximar de tendências liberais, pois a opressão estatal existe por conta da necessidade de defender o sistema econômico de exploração. É uma anticapitalismo que não acredita nessa oposição colocada há muito tempo no movimento socialista em que o Estado deve atuar contra o mercado para fundar uma nova sociedade. Só existe uma sociedade de mercado funcionando porque existe o Estado pra reprimir. A autonomia não é relacionada apenas ao partido e ao poder do Estado, mas também a empresas. Não significa que nós iremos enfrentar o estado ignorando as leis vigentes ou deixar de nos relacionar com as empresas, afinal estamos no Facebook. A gente se relaciona com corporações no sentido de ter que se adequar a alguns instrumentos pra divulgar materiais. Não se nega o diálogo com o Estado. Negase um dirigismo do Estado ou de quem disputa o Estado. Em uma luta como a do MPL, seria muito fácil desmobilizar se bastasse uma reunião com uma liderança. É fácil ver isso no funcionamento das estruturas sindicais no Brasil. É assim em boa parte do mundo. Há um enorme movimento grevista, aí você conversa com um líder sindical e acabou. $\mathrm{O}$ que desconcertou as autoridades e a mídia em junho foi o fato de que o MPL não era dirigível. A Veja inventou lideranças políticas que não tinham respaldo nenhum. A autonomia permite um movimento mais combativo, um aprendizado com relação a uma estrutura de poder não hierarquizada e uma independência do capital e do poder estatal.

\section{5-Você nota um avanço na forma de organização do Baderna Midiática?}

Durante a primeira ação, eu tive um papel que eu deixei muito claro que depois eu não queria ter. Eu tive um papel organizativo muito maior do que outras pessoas. Depois disso, a gente repensou a divisão do trabalho. Hoje eu acho que as coisas estão funcionando razoavelmente bem. As ações são definidas coletivamente reuniões combinadas por uma lista de e-mail. Às vezes a gente usa o grupo fechado no Facebook pra replicar conteúdos da lista porque algumas pessoas demorar pra ver email. Nas reuniões, a gente faz um balanço das últimas ações e decide a partir de ideias de membros do coletivo o que fazer daqui pra frente. Tudo o que é de deliberação é colocado ali. Um membro do coletivo que mora na França participa das reuniões via câmera ou IRC. O Tiago, membro do coletivo, trouxe uma proposta de poema baseado num poema do Arnaldo Antunes usado na propaganda da Natura. A gente passou muito 
tempo debatendo frase por frase até chegar, por consenso, ao texto final. O tipo de organização através de consenso requer estruturas pequenas. Ele não serviria para uma organização de massas, a não ser que fosse fragmentada em pequenos núcleos. $\mathrm{O}$ nosso coletivo não tem a pretensão de crescer e se tornar muito maior que isso. A gente quer se manter como um coletivo de mídia que vai muito mais auxiliar os debates do que cumprir uma tarefa organizativa ou de mobilização. Eu imagino que a gente nunca vá convocar nada porque a gente não é um movimento que pretende se massificar.

Nas primeiras reuniões, estava claro que a gente ia usar as mídias sociais corporativas. Com o contato com militantes mais experientes, a gente percebeu que era necessário ter o conteúdo em um espaço que não o Facebook e Youtube por conta do controle da informação. A gente usa rise up pra comunicação com lista de e-mail, ainda que nem todos costumem frequentar. O blog na plataforma Milharal surgiu de conversas com gente do CMI. Tudo o que a gente publica no Facebook de conteúdo próprio vai também para o blog.

\section{6-O que vocês costumam compartilhar no Facebook?}

Geralmente conteúdos de coletivos autônomos. Feira Anarquista, convocação do MPL, alguns vídeos do Mídia Negra. Alguns coletivos já nos pediram pra divulgar algumas coisas. O pessoal Mobilização Nacional Indígena pediu pra gente assinar o manifesto e divulgar o conteúdo. A gente discutiu e resolver fazer isso.

\section{7-Qual a importância de fortalecer a parceria com outros coletivos?}

As reuniões que mencionei de coletivos e indivíduos autônomos de São Paulo em junho foram uma tentativa de organização do que virou a Rede Protesta. A ideia nasce integrada ao diálogo das pessoas que compõem essa rede. Nem sempre participamos das reuniões, por isso não somos muito atuantes da rede. Como ainda não temos uma rotina definida de trabalho, temos uma dificuldade de construir essa articulação. A gente conversou com o Mídia Negra pra estabelecer um diálogo e atividades futuras. Com o CMI a gente tem contato mais direto porque a Tai, uma das integrantes do Baderna, já participou coletivo.

\section{8-O que os aproxima desses coletivos e o que os afasta de grupos como o Mídia Ninja?}

O CMI sempre deixou clara sua militância anticapitalista e autônoma. O Mídia Negra também veio desse ambiente habitado por pessoas com as quais tínhamos uma relação de confiança. Em contraposição, a gente já tinha noção, pela experiência de outros militantes, do que era o Mídia Ninja. O Mídia Ninja nasce como uma empresa com uma estrutura hierarquizada e com relação muito íntima com o PT e a Rede, da Marina. É muito mais um instrumento de cooptação do que um movimento social ou um coletivo.

\section{9-A Revista Fórum publicou uma matéria sobre o coletivo. Como é a relação do Baderna com os veículos de comunicação à esquerda?}

A Revista Fórum fez uma matéria muito legal sobre o hino à rua. Tentaram nos entrevistar, mas não deu certo. Não temos nenhuma relação direta sobre esses meios. Não há problema em divulgar esses conteúdos, desde que seja de boa qualidade e que de preferência possamos estabelecer um contato crítico com eles. É um conjunto de mídia que se coloca à esquerda, não se confunde com a mídia conservadora, mas ainda assim é empresarial. Alguns desses veículos estão vinculados, institucionalmente ou não, à 
defesa do governo do PT. A Revista Fórum é um pouco mais interessantes que outras como a Carta Capital - que é bem governista - e que alguns blogueiros que defendem qualquer coisa que o governo federal fizer. Existem veículos, apesar de empresariais e defensores do projeto do PT, com os quais é possível ter um diálogo em alguns momentos porque existem bons jornalistas lá e algum compromisso ético.

\section{0-Qual a importância da disputa simbólica na qual o Baderna pretende entrar para a transformação da sociedade?}

Ela é um pedaço bem pequeno disso. A gente atua como um detalhe, que pode ser precioso em certos momentos, mas é um detalhe de uma luta que vai bem além disso. A luta social a partir de uma atuação de base, de um trabalho organizativo na sociedade especialmente nas classes populares, é que é fundamental. O trabalho que o MPL, os movimentos de sem teto e os movimentos do campo fazem são é muito mais importante em termos de transformação social do que o trabalho que a gente faz. Pode ser um instrumento importante em alguns momentos, mas não é isso que vai transformar a sociedade.

A exclusão digital é real. Muitas pessoas sequer têm hábito de acessar a internet. Quando dei aula num curso superior no sul de Minas, alunos com mais de vinte anos estavam aprendendo a usar a internet. As pessoas se relacionam de maneiras diferentes com a internet. Nas próprias redes sociais existem certos de linguagens e conteúdos que circulam de acordo com diferentes grupos sociais. Isso tem a ver com a educação formal que está diretamente ligada à questão de classe. A questão da linguagem é um problema pra gente. Acho que a exclusão social é menor do que antes e tende a diminuir mais. $\mathrm{O}$ fenômeno dos rolezinhos mostra isso. Há um grande acesso da juventude à internet. Obviamente, o trabalhador pobre que tem mais de 30 anos é outra história.

A gente tem ideia de um dia se envolver mais com a divulgação dos nossos conteúdos de outras formas. Divulgar os conteúdos em eventos ligados a redes culturais das periferias. É difícil fazer um contradiscurso sendo que a gente vem de uma formação de ensino superior. A maioria de nós é, no mínimo, de classe média baixa. A gente precisa estruturar uma linguagem que dê conta disso. Até agora a gente não conseguiu fazer muito bem isso. Os nossos textos ainda têm certo ranço de uma militância que fala pra iniciados, pra que já está envolvido no debate político. Acho que isso é experimental porque é uma realidade nova. Eu tenho tentado lidar com isso quando faço os memes. Mesmo no humor, os públicos são diferentes. Quem entende aquelas piadas tem algumas referências do que é a militância e de quem são os personagens. A página "A revolução será orkutizada" é seguida majoritariamente por militantes de esquerda. A página "Agrega valor ao camarote", que tem 225 curtidas, é outra história. Quando eu publico alguma coisa politizada, os seguidores não gostam, me chamam de petista.

Eu acho que toda teoria de classes precisava ser revista há muito tempo. Tenho uma forte influência marxista, mas acho que essa teoria de classes vem de experiência histórica muito específica da Europa do século 19. E no Brasil, mesmo com a importância que a fábrica teve na primeira metade do século 20, a fábrica nunca ocupou todo o espaço das lutas sociais. Nos grandes conflitos da república velha, houve grandes movimentos que não tiveram nada a ver com o movimento operário stricto senso. Faltou muito essa percepção de que a luta popular não é só uma luta do trabalho contra o capital. A luta envolve setores populares das mais diversas formas em seus cotidianos tanto nas relações de trabalho quanto em outras relações de opressão, incluindo as formas de opressão estatal. A distribuição desigual da violência da cidade é um ponto. 
Hoje em dia a violência unifica mais o discurso das periferias pobres do que a exploração do trabalho que acontece de maneira muito mais difusa. Acho que o movimento autônomo teve uma leitura mais aberta disso. Falar "lutar com os de baixo e à esquerda" traz uma abertura muito maior a uma possibilidade de articulação popular dos explorados do que o ambiente da fábrica que nunca centralizou as lutas sociais no Brasil. Isso foi na Inglaterra industrial do século 19. O Marx achou que aquilo ia virar pro mundo inteiro, mas nunca se tornou um paradigma de sociedade em todos os lugares do mundo.

\section{1-Qual a proposta do Calendário Insurrecional Brasileiro?}

O Calendário Insurrecional do Brasil. Logo que a gente começou a se reunir, eu propus a retomada desse projeto eu tinha desenvolvido até 12 de junho de 2012. Como não dei conta, escrevi um texto chamando pessoas pra colaborar, mas ninguém se envolveu. Os outros membros do Baderna aceitaram a proposta e resolvemos começá-lo em 2014. Hoje é um projeto do coletivo. A proposta do calendário tem uma relação com o tempo e a história não cronológica. A cada dia dá um salto no passado e traz um assunto atual. Tem relação com a trajetória de violência no Brasil dentro de dois grandes temas: as lutas populares e a violência estatal ou privada. Pra além de um discurso evolutivo. Quebra o discurso nacionalista de progresso e povo ordeiro.

\section{2-Quais as expectativas para o ano de 2014?}

A gente não tem muita coisa definida do que fazer ao longo do ano. A gente está para se reunir agora. $\mathrm{O}$ que tem fechado é continuar com calendário até 31 de dezembro. Nós temos um vídeo encaminhado que tem a ver com a questão das armas menos letais, nos sentido de instruir como lidar com essas armas. De alguma maneira, a gente vai ter que lidar com o fato de que vai haver um circo eleitoral. A ideia do coletivo é se engajar naquilo que parecer uma prioridade em cada momento. A gente não estabelece prognósticos a longo prazo, a não ser o Calendário que é uma coisa fixa. 